\title{
Arbeidsmarktmonitor metalektro : editie 2010
}

Citation for published version (APA):

Kriechel, B., de Grip, A., van Breugel, G. A. A., \& Coenen, J. B. (2010). Arbeidsmarktmonitor metalektro : editie 2010. Researchcentrum voor Onderwijs en Arbeidsmarkt, Faculteit der Economische Wetenschappen. ROA Reports No. 5 https://doi.org/10.26481/umarep.2010005

Document status and date:

Published: 01/01/2010

DOI:

10.26481/umarep.2010005

Document Version:

Publisher's PDF, also known as Version of record

\section{Please check the document version of this publication:}

- A submitted manuscript is the version of the article upon submission and before peer-review. There can be important differences between the submitted version and the official published version of record.

People interested in the research are advised to contact the author for the final version of the publication, or visit the DOI to the publisher's website.

- The final author version and the galley proof are versions of the publication after peer review.

- The final published version features the final layout of the paper including the volume, issue and page numbers.

Link to publication

\footnotetext{
General rights rights.

- You may freely distribute the URL identifying the publication in the public portal. please follow below link for the End User Agreement:

www.umlib.nl/taverne-license

Take down policy

If you believe that this document breaches copyright please contact us at:

repository@maastrichtuniversity.nl

providing details and we will investigate your claim.
}

Copyright and moral rights for the publications made accessible in the public portal are retained by the authors and/or other copyright owners and it is a condition of accessing publications that users recognise and abide by the legal requirements associated with these

- Users may download and print one copy of any publication from the public portal for the purpose of private study or research.

- You may not further distribute the material or use it for any profit-making activity or commercial gain

If the publication is distributed under the terms of Article $25 \mathrm{fa}$ of the Dutch Copyright Act, indicated by the "Taverne" license above, 


\title{
Arbeidsmarktmonitor Metalektro
} Editie 2010

\author{
Ben Kriechel \\ Andries de Grip \\ Gerla van Breugel \\ Johan Coenen
}

ROA-R-2010/5 


\section{Colofon}

(C) Researchcentrum voor Onderwijs en Arbeidsmarkt (ROA). Niets uit deze uitgave mag op enige manier worden verveelvoudigd zonder voorafgaande schriftelijke toestemming van de directeur van het ROA.

\section{Researchcentrum voor Onderwijs en Arbeidsmarkt}

School of Business and Economics

Maastricht University

\section{Vormgeving}

ROA secretariaat, Maastricht

\section{Verkoop}

Researchcentrum voor Onderwijs en Arbeidsmarkt email: secretary-roa-sbe@maastrichtuniversity.nl website: www.roa.nl

ISBN: 978-90-532I-486-2

mei 2010 


\section{Inhoud}

Voorwoord

Management Summary

vii

1 Dynamiek in de Metalektro 1

1.1 Metalektro en de crisis 1

1.2 Crisismaatregelen 3

$\begin{array}{ll}1.3 \text { Werkgelegenheidsontwikkeling } & 6\end{array}$

$\begin{array}{ll}1.4 \text { Innovatie } & 7\end{array}$

2 Metalektro in het crisisjaar 2009 11

2.1 Quickscan-monitor $\quad 11$

2.2 Werknemers aangesloten bij PME 14

2.3 Leerbanen en Stageplekken 16

3 Arbeidsmarktontwikkelingen in $2009 \quad 19$

3.1 Personeelsuitstroom in de Metalektro 19

3.2 Personeelsinstroom in de Metalektro $\quad 21$

3.3 Recente werkgelegenheidsontwikkelingen $\quad 25$

3.4 Flexibele arbeid in de Metalektro $\quad 27$

3.5 Vacatures in de Metalektro $\quad 29$

3.6 Vrijwillig vertrek en werving van technisch personeel 32

4 Loopbaanmanagement $\quad 37$

4.1 Vaststellen huidig en gewenst competentieniveau 37

4.2 Competentieniveau van de schoolverlaters $\quad 40$

4.3 Ontwikkeling competenties door scholing 46

4.4 Ontwikkeling competenties door interne mobiliteit 53

4.5 Loopbaanmanagementinstrumenten: een totaaloverzicht 55

5 Sociale innovatie 59

5.1 Organisatie en management: implementatie $\quad 59$

5.2 Organisatie en management: doelen 63

5.3 Benutting en ontwikkeling van menselijk kapitaal 66

$\begin{array}{lll}5.4 \text { Externe samenwerking } & 71\end{array}$ 
6 Vergrijzing en active ageing beleid 75

6.1 Uitstroom door vergrijzing en vervangingsproblemen 75

6.2 Aanpak vervangingsproblemen door vergrijzing 80

6.3 Active ageing $\quad 82$

7 De Metalektro in de toekomst $\quad 85$

7.1 Arbeidsmarktontwikkeling in de Metalektro op de korte termijn: 2010-2011 85

7.2 Ontwikkelingen op de middellange termijn: 2010-2014 87

7.3 Verandering in de technische functies op de middellange
termijn: 2010-2014

7.4 HRM beleid op de middellange termijn: 2010-2014 91

8 Agenda voor de Toekomst $\quad 95$

8.1 Ontwikkelingen en trends 95

8.2 Agenda voor de Toekomst 99 


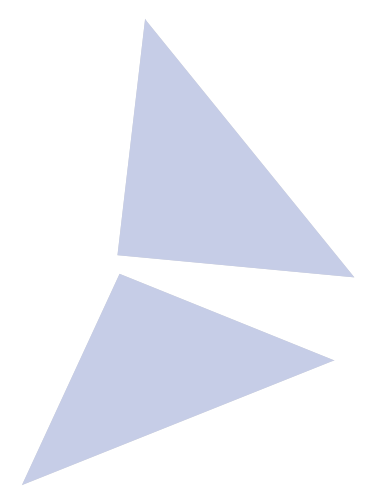

\section{Voorwoord}

In 2002 is in opdracht van de Stichting $\mathrm{A}+\mathrm{O}$ een start gemaakt met de opzet van een Arbeidsmarktmonitor voor de Nederlandse Metalektro. Deze monitor geeft inzicht in de actuele ontwikkelingen op de arbeidsmarkt en de toekomstige ontwikkelingen op personeels- en arbeidsmarktgebied in de Metalektro. Deze rapportage vormt de afsluiting van de achtste jaarcyclus van de Arbeidsmarktmonitor. Het rapport combineert de belangrijkste resultaten van het voor de monitor opgezette Werkgeverspanel Metalektro en de Quickscans met informatie uit diverse andere bronnen. Om dieper te kunnen ingaan op de achtergronden van de ontwikkelingen, de problemen en de knelpunten waarmee bedrijven in de Metalektro te maken hebben, is een aantal gesprekken georganiseerd. De gesprekken zijn verwerkt tot tekstkaders waarin de meningen van bedrijven over een aantal onderwerpen kernachtig worden samengevat. Deze tekstkaders zijn door het hele rapport verspreid en vormen een waardevolle aanvulling op de informatie die in de hoofdtekst wordt gepresenteerd.

In 2009 zijn de metalektrobedrijven twee keer benaderd om mee te doen aan het Werkgeverspanel. Telkens beantwoordt een representatieve groep bedrijven uit de Metalektro via internet een lijst met vragen over de in- en uitstroom van het personeel in de zes maanden voorafgaand aan de meting en het aantal openstaande vacatures. Naast deze standaardvragen wordt in iedere meting ingegaan op bepaalde thema's zoals werving en selectie, de inzetbaarheid en de doorstroom van personeel, sociale en technologische innovatie en de competenties en scholing van het technisch personeel. Ook in 2009 is veel aandacht besteed aan het verder verbeteren van de vraagstellingen in het Werkgeverspanel. Door nieuwe vragen te introduceren en bestaande vragen verder aan te scherpen is geprobeerd om de informatie die het Werkgeverspanel oplevert nog beter af te stemmen op de informatiebehoefte van de bedrijven.

Bij de start van het panel in 2002 zijn alle metalektrobedrijven benaderd om deel te nemen aan het Werkgeverspanel. Vanaf 2006 is dit uitgebreid met een Quickscan die twee keer per jaar gehouden wordt. Daarin wordt bedrijven gevraagd hun mening te geven over een drietal stellingen. Deze Quickscan is in 2009 uitgebreid naar vier meetmomenten. Ook is een monitorgedeelte met vijf vragen toegevoegd, over actuele en verwachte veranderingen in werknemers, vacatures en de duur van openstaande vacatures. Zo schetsen wij ook tussen de jaarrapportages in een beeld van de actuele ontwikkelingen in de Metalektro. 
Om een representatief beeld te kunnen geven van de ontwikkelingen in de Nederlandse Metalektro wordt de informatie die de deelnemende bedrijven aanleveren gewogen naar bedrijfsomvang, bedrijfssector en regio. Om vervolgens uitspraken te kunnen doen over bijvoorbeeld het totale aantal vacatures dat in de Metalektro openstaat, is het aantal vacatures dat bij de deelnemende bedrijven openstaat opgehoogd. Deze ophoging van vacaturecijfers komt overeen met de procedure die het CBS volgt in hun landelijke vacature-enquête. Deze aanpak heeft als voordeel dat we een goed beeld kunnen geven van de ontwikkeling van het totale aantal vacatures dat bij de bedrijven in de Metalektro openstaat. Ook de cijfers over de in- en uitstroom van werknemers in de Metalektro zijn opgehoogd tot in de tijd vergelijkbare totaalcijfers voor de hele Metalektro.

$\mathrm{Na}$ iedere meting van het Werkgeverspanel Metalektro worden de uitkomsten gepubliceerd in een door de Stichting $\mathrm{A}+\mathrm{O}$ uitgegeven nieuwsbrief. In deze nieuwsbrieven wordt niet alleen gerapporteerd over de actuele arbeidsmarktsituatie (vacatures, instroom en uitstroom, werkgelegenheidskrimp) en de arbeidsmarktverwachtingen voor de komende periode, maar komen ook andere trends en ontwikkelingen aan de orde. Daarnaast bevat iedere nieuwsbrief een redactioneel commentaar waarin wordt ingegaan op de dynamiek in de Metalektro en de situatie op de arbeidsmarkt. Door de ontwikkelingen in de Metalektro in een wat breder perspectief te plaatsen wordt meer inzicht gegeven in de gevolgen van bepaalde trends en problemen en wat dit voor het beleid kan betekenen. Ieder deelnemend bedrijf ontvangt ook nog een bedrijfsfoto. Dit benchmarkinstrument vergelijkt de positie van het eigen bedrijf met het algemene beeld van de bedrijfstak.

De inbreng en de betrokkenheid van de deelnemende bedrijven blijft cruciaal om de Arbeidsmarktmonitor Metalektro verder te ontwikkelen en draagt er toe bij dat de monitor een instrument is vóór en dóór de bedrijven. Daarom willen we de bedrijven die de halfjaarlijkse vragenlijsten en/of de Quickscans hebben ingevuld van harte bedanken. Een speciaal woord van dank willen we op deze plaats richten aan de bedrijven die bereid waren om deel te nemen aan de verdiepende gesprekken. De uitvoering van de Arbeidsmarktmonitor Metalektro en het samenstellen van deze jaarrapportage staat onder leiding van een regiecommissie. Deze commissie bestaat uit de volgende leden: Henry de Groot (Stichting A+O), Rien Smit (FME-CWM), Astrid Ophof (FNV Bondgenoten). De auteurs van dit rapport willen de leden van deze regiecommissie hartelijk bedanken voor hun constructieve feedback en de wijze waarop ze het onderzoek begeleid hebben. Het veldwerk voor het Werkgeverspanel Metalektro is uitgevoerd door Marije Oudejans van CentERdata. Sander Dijksman (ROA) werkte mee aan de statistische analyses in dit rapport. 


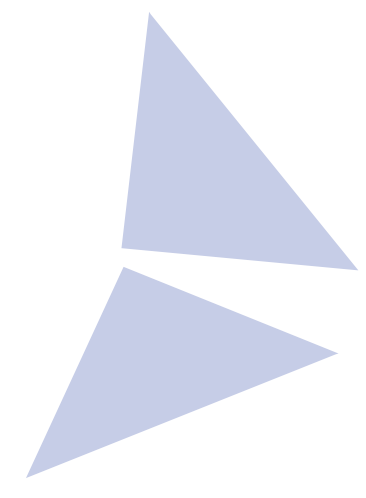

\section{Management Summary}

Management Summary

\section{Metalektro in het teken van de crisis}

Volgens de conjunctuurindicator van het CBS lag het hoogtepunt van de crisis voor de Metalektro rond de zomer van 2009 toen $60 \%$ van de bedrijven belemmeringen ondervonden. Dit is de hoogste stand van de conjunctuurindicator voor de Metalektro in de laatste twintig jaar. Met name in de eerste helft van 2009 was er in de Metalektro sprake van een hoge personeelsuitstroom. Daarentegen was de instroom zowel in de eerste als de tweede helft van dat jaar laag. De totale werkgelegenheid daalde dan ook in alle regio's en functies.

In deze tijd hadden metalektrobedrijven veel baat bij hun flexibele schil. Zo verminderde in de eerste helft van 2009 tweederde van de bedrijven het aantal ingeleende uitzendkrachten. In de tweede helft van 2009 was er in de helft van de bedrijven sprake van een verdere vermindering van het aantal uitzendkrachten. Daarnaast werden tijdelijke contracten in heel 2009 minder vaak verlengd dan voor de crisis.

De metalektrobedrijven proberen echter de kennis en vaardigheden van het vaste personeel zo veel mogelijk te behouden. Daarom haalde al in het begin van 2009 bijna de helft van de bedrijven de voorheen aan andere bedrijven uitbestede werkzaamheden terug naar het eigen bedrijf. Ook wordt het personeel in toenemende mate anders ingezet: eind 2009 laat ongeveer de helft van de bedrijven het personeel andere werkzaamheden uitvoeren of scholing volgen. Verschillende bedrijven deden dit met behulp van de wtv-regeling of de deeltijd-WW. Dit alles heeft echter niet kunnen voorkomen dat het aantal medewerkers in de Metalektro in 2009 duidelijk is teruggelopen. De crisis heeft er vanzelfsprekend toe geleid dat het aantal vacatures aanzienlijk is afgenomen. Er waren sinds het bestaan van de Arbeidsmarktmonitor Metalektro nog nooit zo weinig vacatures in de Metalektro als in 2009 en de vacatures die er zijn, worden veel sneller vervuld dan voorheen. De eerste tekenen van herstel van het aantal vacatures hebben zich echter al wel weer aangediend.

Verschillende bedrijven zijn door de economische crisis ook de speerpunten van hun toekomstig personeelsbeleid gaan herzien of uitstellen. Vooral speerpunten met 
betrekking tot scholing van het personeel, bijvoorbeeld het stimuleren van cursusdeelname en het intensievere samenwerken met onderwijsinstellingen, worden minder vaak genoemd.

De crisis had ook negatieve gevolgen voor het aantal stageplaatsen en leerbanen binnen de Metalektro. Desondanks zijn deze nog in voldoende mate aanwezig, aangezien een groot percentage van de beschikbare beroepsvormingsplaatsen nog steeds onbezet is.

\section{Structurele Ontwikkelingen}

\section{Arbeidsmarkt}

De metalektrobedrijven verwachten dat de trendmatige daling van de werkgelegenheid voor LBO-ers ten gunste van een groeiende werkgelegenheid voor MBO-ers en HBO-ers zich de komende jaren zal doorzetten. De verschuiving wordt zelfs versterkt door de crisis. Ondanks de huidige terugval in het aantal vacatures verwachten veel bedrijven voor de komende vijf jaar problemen bij de vervanging van hun personeel dat met pensioen gaat. Een langetermijnpersoneelsplanning in combinatie met een goed wervingsbeleid blijven dus van groot belang om vervangingsproblemen te voorkomen.

\section{Technologische innovaties}

Innovaties blijven van groot belang voor het handhaven van de concurrentiepositie van de bedrijven in de Metalektro. Meer dan de helft van de bedrijven heeft een innovatiegerichte strategie of is bezig deze te implementeren. De crisis lijkt geen invloed te hebben gehad op de innovatiekracht van de bedrijven. Het percentage bedrijven dat één of meer technologische innovaties gerealiseerd heeft, was ook in 2009 hoog en de bedrijven verwachten dat ze in 2010 qua technologische innovaties op hetzelfde niveau zullen presteren als in 2009 . Naast product- en procesinnovaties is de ontwikkeling van nieuwe productondersteunende diensten een innovatie in opkomst: ruim een kwart van de bedrijven verwacht binnen de komende vijf jaar met een dergelijke dienst op de markt te komen.

\section{Sociale Innovaties}

Metalektrobedrijven komen niet alleen steeds vaker met nieuwe productondersteunende diensten. Ook proberen ze steeds vaker om door sociale innovaties de bedrijfsprestaties te verbeteren. Daarbij richten bedrijven zich onder andere op:

- de organisatie van het werk,

- het management,

- het beter benutten van kennis en vaardigheden van het personeel en

- het zoeken naar nieuwe vormen van samenwerking. 
In negen van de tien bedrijven werd in 2009 minimaal één sociale innovatie doorgevoerd. Per bedrijf ging het daarbij vaak om meerdere vormen van sociale innovatie.

De doelstellingen van sociale innovaties liggen vooral op het terrein van het verbeteren van de productiviteit en het produceren van meer hoogwaardige producten. Daarnaast wordt het flexibiliseren van het productieproces vaak als het doel van een sociale innovatie genoemd. Bij de implementatie van sociale innovaties geeft driekwart van de bedrijven aan dat deze naar wens verlopen is. De problemen die bedrijven bij het implementeren van sociale innovaties ondervinden, hebben vooral betrekking op het tekortschieten van de kennis en vaardigheden van het personeel en het gebrek aan tijd of menskracht. Ter ondersteuning van sociale innovatie gaat bij de metalektrobedrijven de meeste aandacht het komende jaar uit naar HR-instrumenten die gericht zijn op de planmatige ontwikkeling van het personeel, zoals loopbaanplanning, bedrijfs- en persoonlijke opleidingsplannen, EVC's en competentiemanagement. Zo hopen de bedrijven hun personeel voor te kunnen bereiden op de toekomst.

POFI+

De verandering in de inhoud van veel functies zet zich onveranderd voort. Daarbij verwachten veel bedrijven ook dat zij hun personeel breder zullen gaan inzetten. Ruim de helft van de bedrijven verwacht dat door deze ontwikkelingen gedragsmatige competenties, zoals deze zijn samengevat in de POFI+ agenda, belangrijker worden. Daarbij gaat het om de volgende competenties:

- probleemoplossend vermogen,

- omgaan met veranderingen,

- omgaan met klanten,

- flexibiliteit en

- initiatief.

\section{Training}

Het ontwikkelen van medewerkers is gezien het innovatieve karakter van de bedrijfstak van groot belang. Het personeel dient immers op elk moment over de juiste competenties en kennis te beschikken. De bedrijven proberen dit onder andere te bereiken door trainingen, learning-on-the-job, maar ook door bewuste taakroulatie.

De gevolgen van de crisis vertalen zich ook naar de trainingen: door de terugval van de afzet is er weliswaar meer tijd, maar daarentegen minder geld om in de scholing van het personeel te investeren. Veel bedrijven lossen dit op door hun medewerkers vooral meer binnen het bedrijf bij te scholen, liefst zonder al te hoge out-of-pocket kosten. Hierdoor is de trainingsdeelname bij interne cursussen gestegen, terwijl de trainingsdeelname aan externe cursussen ten opzichte van 2008 gelijk is gebleven. De vereiste upgrading van het personeel en de toenemende vraag naar technici die beschikken over de genoemde POFI+ competenties vergen aanzienlijke investeringen 
in trainingen en opleidingen voor het personeel. Het is dan ook niet verwonderlijk dat de opleidingsuitgaven van de metalektrobedrijven, ondanks de druk van de economische crisis, in procenten van de loonsom in 2009 weer verder zijn gestegen. De gemiddelde out-of-pocket opleidingskosten per getrainde werknemer zijn echter licht gedaald. Naast de vaktechnische cursussen verwachten bedrijven de komende jaren meer aandacht te besteden aan cursussen ter ontwikkeling van de competenties uit de POFI+ agenda.

\section{Vervangingsproblematiek}

Voor de komende vijf jaar verwachten de bedrijven een daling van het percentage werknemers dat met pensioen gaat. De vervangingsproblematiek wordt aangepakt door de instroom van nieuwe werknemers, door het bedrijf aantrekkelijker te maken als werkgever, gebruik te maken van arbeidsbesparende vernieuwingen van het productieproces en door binnen het bedrijf de loopbaanplanning van het zittende personeel te verbeteren. De inzet van active ageing instrumenten in het personeelbeleid bereikte in 2009 echter een dieptepunt. Door de crisis waren bedrijven eerder geneigd om hun oudere werknemers te stimuleren om met pensioen te gaan, dan ze tot langer doorwerken te stimuleren. Dit betekent dat dit arbeidspotentieel voor de Metalektro helaas verloren is gegaan. 


\section{Dynamiek in de Metalektro}

De crisis had de Metalektro in 2009 stevig te pakken. Veel maatregelen werden genomen om de crisis goed te doorstaan. In dit hoofdstuk worden in vogelvlucht de belangrijkste arbeidsmarktontwikkelingen van 2009 besproken. Paragraaf I.I schetst de conjuncturele situatie in de Metalektro en vervolgens wordt in paragraaf I. 2 ingegaan op de maatregelen die bedrijven hebben genomen naar aanleiding van de crisis. De algemene werkgelegenheidsontwikkeling wordt beschreven in paragraaf I.3 en dit hoofdstuk wordt afgesloten met de technologische innovaties in de Metalektro.

\subsection{Metalektro en de crisis}

De economische omstandigheden waren slecht voor de Metalektro in 2009. Hoewel de crisis al in de herfst van 2008 begon voelden veel bedrijven de gevolgen van de crisis pas in het begin van 2009. Ook het lang aanhouden van de crisis over het gehele jaar 2009 heeft zijn weerslag gehad in de resultaten van deze Arbeidsmarktmonitor. Hoe uitzonderlijk de situatie voor de Metalektro was, is duidelijk terug te zien in de gegevens van het CBS. In de kwartaalgegevens van de CBS conjunctuurtest draait het om mogelijke productiebelemmeringen waarmee bedrijven te kampen hebben. Om de gevolgen van de crisis in kaart te brengen, geeft figuur I.I de productiebelemmeringen van de afgelopen drie jaar weer. Daarna is in figuur I.2 de langetermijnontwikkeling te zien. De eerste figuur laat dus duidelijk de veranderingen van de afgelopen jaren zien, terwijl de tweede figuur de omvang van de crisis weergeeft in het perspectief van de laatste twee decennia.

In beide figuren staan de volgende drie aspecten centraal: belemmeringen door personeelstekort, belemmeringen door onvoldoende vraag van afnemers - als indicator voor de vraag naar hun producten, waarmee bedrijven geconfronteerd worden - en een indicator dat er geen belemmeringen zijn geweest. Deze laatste indicator geeft dus aan dat bedrijven zonder problemen hun producten kunnen produceren en ook verkopen.

De overgang van een goed lopende economische situatie naar een situatie van economische crisis is duidelijk in figuur I.I te herkennen. De stippellijn geeft het percentage bedrijven aan dat niet met productiebelemmeringen geconfronteerd wordt. Dit ligt begin 2008 tussen de $70 \%$ en $80 \%$, maar valt daarna terug op een niveau tussen de 
$40 \%$ en $50 \%$. Interessant is dat in de overgangsperiode (eind 2008 tot en met begin 2009) nog een combinatie van belemmerende factoren optreedt. Sommige bedrijven geven aan door personeelstekorten minder te produceren, terwijl anderen al onder hun productiecapaciteit moeten werken door een terugvallende vraag. In de loop van de eerste helft van 2009 valt de productiebelemmering door personeelstekorten echter nagenoeg weg, en is een onvoldoende vraag naar de producten de hoofdoorzaak van de productiebelemmeringen. Begin 2010 heeft $40 \%$ van de bedrijven hiermee te kampen.

Figuur 1.1

Productiebelemmering in de Metalektro (\% bedrijven)

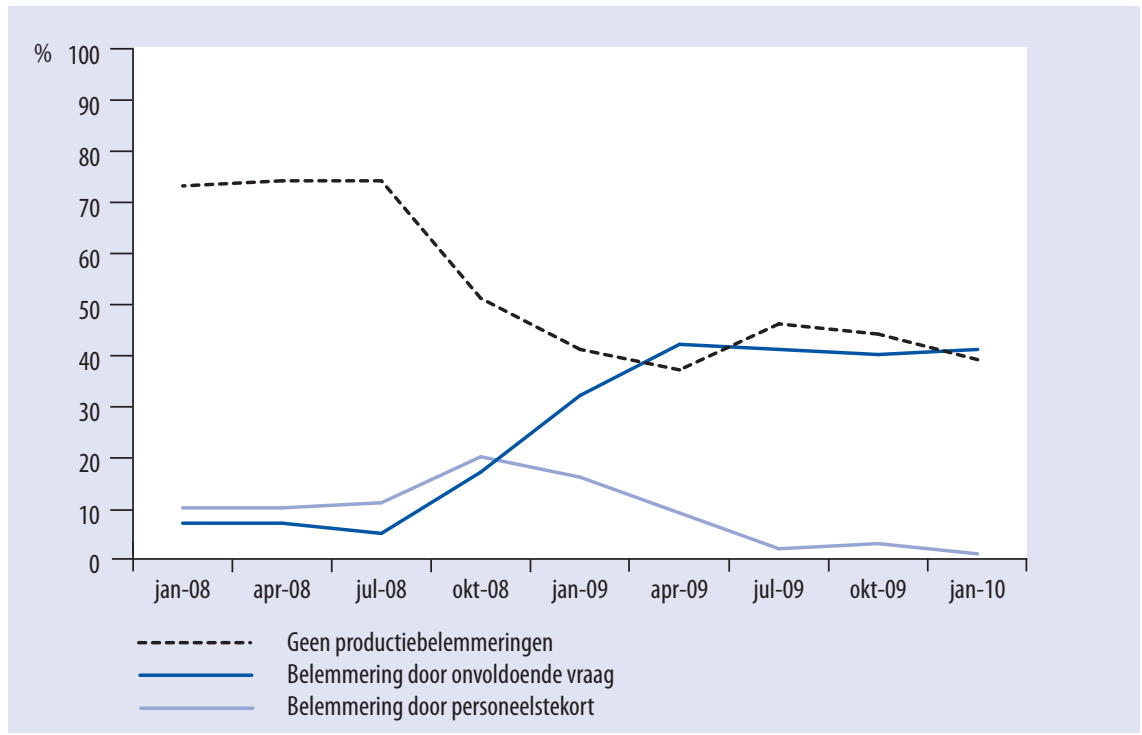

Bron: CBS Conjunctuurtest Industrie 2008-2010 (SBI: 27)

Figuur I.2 laat zien hoe uitzonderlijk de in figuur I.I. geschetste situatie is. Nog nooit eerder is het het percentage bedrijven zonder productiebelemmeringen in de afgelopen twintig jaar zo laag geweest. Meer dan de helft van bedrijven geeft aan productiebelemmeringen te ondervinden. In eerdere jaren fluctueerde deze index tussen de $70 \%$ en de $90 \%$ van de bedrijven. In 1993-94 viel deze indicator zelfs terug onder een niveau van $70 \%$, maar toen gaf nog duidelijk meer dan $60 \%$ van de bedrijven aan geen productiebelemmeringen te ondervinden.

De belemmeringen door onvoldoende vraag weerspiegelen de conjunctuurcyclus voor de Metalektro. Rond 1992 begint deze indicator te stijgen tot een piek van 30\%, waarna deze weer terugvalt tot een laag niveau. In de jaren 200I-2003 is nog een kleinere piek te zien: ongeveer $20 \%$ van de bedrijven kampte in die jaren met een gebrek aan orders. 
Een omgekeerde beweging is te zien bij de belemmeringen door personeelstekorten. Hier zijn meer belemmeringen te verwachten in economisch goede tijden. Onder zulke gunstige omstandigheden is er voldoende vraag naar producten, maar de bedrijven kunnen onvoldoende geschikt personeel vinden om de productie op het hoge niveau te houden. Vooral in de jaren 2006 tot 2008 was dit het geval. Maar ook eind jaren negentig zijn de personeelstekorten een duidelijke belemmering geweest voor de productie in de Metalektro.

\section{Figuur 1.2}

Productiebelemmering in de Metalektro (\% bedrijven)

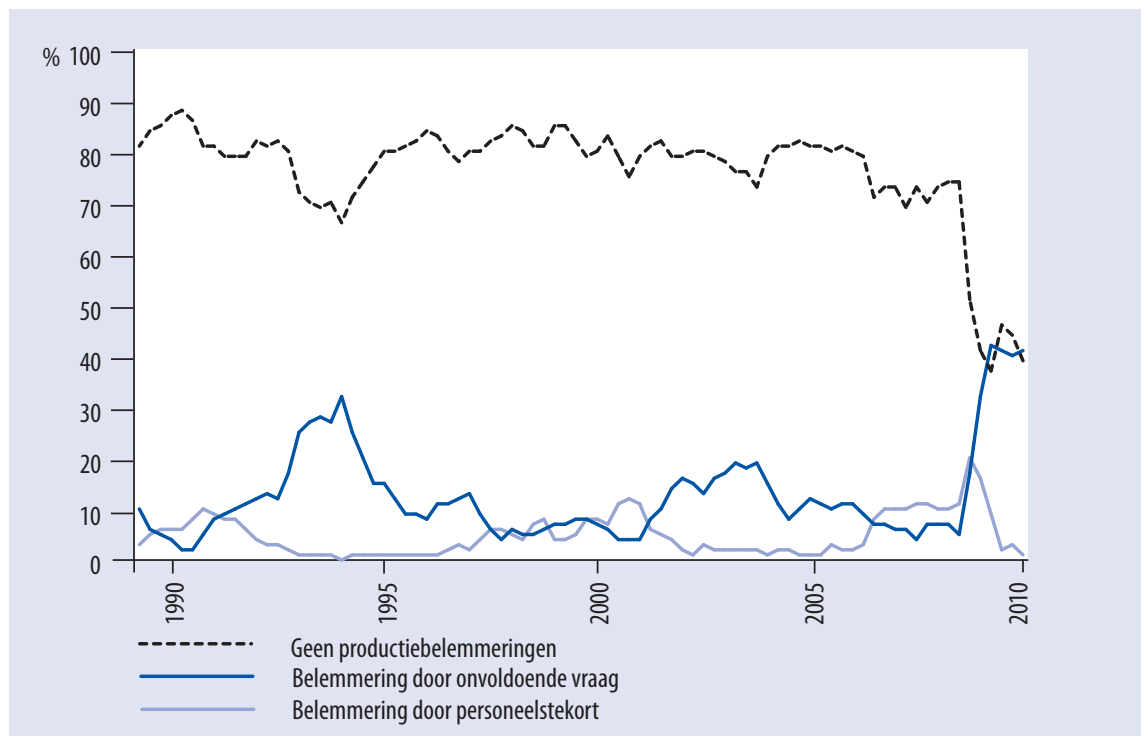

Bron: CBS Conjunctuurtest Industrie 1989-2010 (SBI: 27)

\subsection{Crisismaatregelen}

Tijdens de crisis hebben veel bedrijven de flexibele schil afgebouwd. Deze flexibele schil van uitzendkrachten, gedetacheerd personeel en andere tijdelijke krachten was voor veel bedrijven de buffer. In de Quickscan van september 2009 gaf tweederde van de bedrijven aan dat de flexibele schil erg belangrijk was geweest om de vraaguitval op te vangen. In dezelfde Quickscan werd de bedrijven ook gevraagd naar hun inschatting hoe de overheidsinstrumenten ter overbrugging van de crisis geholpen hebben om het kernpersoneel in dienst te houden: 30\% van de bedrijven gaf aan dat de instrumenten hiervoor onvoldoende waren.

Deze inschatting van de Quickscan is ook terug te vinden in de maatregelen die de bedrijven genomen hebben. Figuur I.5 geeft de genomen maatregelen weer die in de 
afgelopen zes maanden voor elke enquête plaatsgevonden hebben. Dit betreft het tweede halfjaar van 2008 (het begin van de crisis), de eerste helft van 2009 en de tweede helft van 2009. In de antwoordcategorie "we zullen medewerkers ontslaan" is de terughoudendheid van de bedrijven om medewerkers te ontslaan goed te zien. In het begin van de crisis gaf slechts $I 1 \%$ van de bedrijven aan dit te moeten doen. Tijdens de crisis steeg dit percentage tot $21 \%$ in de eerste helft van 2009 en tot $28 \%$ in de tweede helft van 2009. Het afstoten van de flexibele schil heeft voornamelijk in de eerste helft van 2009 plaatsgevonden. Ook tijdelijke contracten worden gaandeweg de crisis steeds minder vaak verlengd. In de tweede helft van 2008 werden tijdelijke contracten in $30 \%$ van de bedrijven niet meer verlengd. Dit aandeel steeg tot $40 \%$ van de bedrijven in heel 2009 .

\section{Figuur 1.3}

Genomen crisismaatregel 2008-2009 (\% bedrijven)

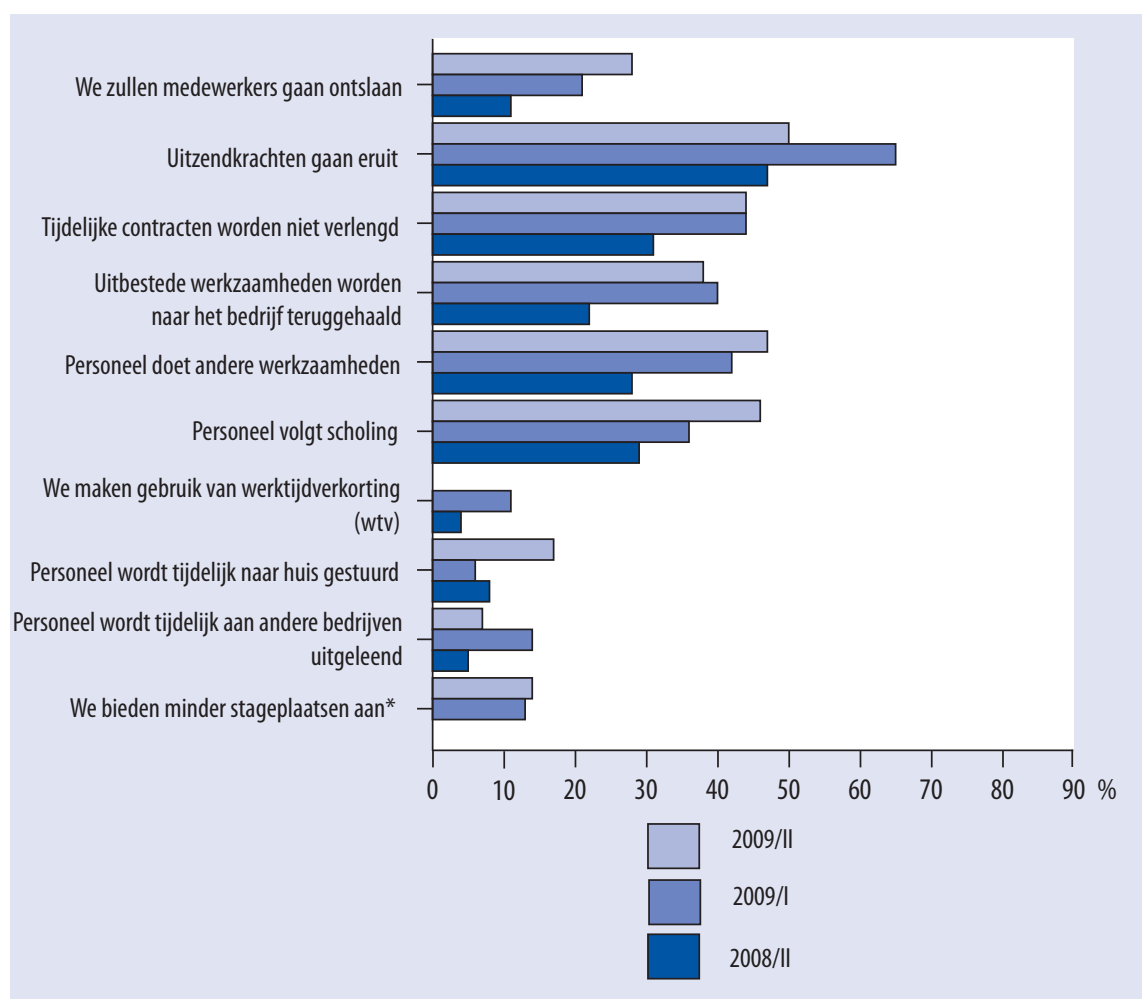

Bron: ROA / Werkgeverspanel Metalektro 2008-2009

* Deze antwoordoptie werd alleen in de metingen 2009/I en 2009/ll gevraagd. 


\section{Wtv en Deeltijd-WW}

Door bedrijven in de Metalektro is veelvuldig gebruik gemaakt van de regelingen wtv en deeltijd-WW, zo ook door de geïnterviewde bedrijven. De aan de regelingen gekoppelde scholingsverplichtingen werden door hen op verschillende manieren ingevuld.

\section{Invulling scholingsverplichting}

Het ene bedrijf haalde al geplande opleidingen naar voren en breidde ze uit. 0ok gaven collega's elkaar voorlichting over het eigen werk zodat iedereen een beter inzicht kreeg in de bijdrage van ieders werk aan het eindproduct en de onderlinge samenhang. Dit werkte motivatieverhogend en daarnaast ontstonden tijdens dergelijke voorlichtingen diverse ideeën voor (proces)innovaties. Het opzetten van interne trainingen die werden gegeven door eigen medewerkers gebeurde sowieso bijzonder veel in de wtv en deeltijd-WW periode: een dergelijke trainingsopzet is relatief goedkoop, biedt maatwerk en mensen in de leegloop worden zo zinvol ingezet.

De scholingstrajecten waren in diverse bedrijven gestoeld op de uitkomsten van EVC-trajecten en persoonlijke ontwikkelplannen (POP's) die men allereerst opstartte. Het laten invullen van POP's heeft een beweging in gang gezet die diverse metalektrobedrijven zien als winst van de crisis. De mensen dachten weer eens na over hun huidige situatie en hun wensen voor de toekomst. In één van de geïnterviewde bedrijven leidde het opstellen van een POP bij enkele werknemers tot de wens om een andere functie en/of een ander bedrijf/organisatie uit te proberen. Aan deze wensen is gehoor gegeven door hen op basis van onbetaald verlof te laten werken bij een ander bedrijf met de garantie dat ze bij de oorspronkelijke werkgever terug kunnen keren als de nieuwe functie of het nieuwe bedrijf niet bevalt. De meeste van deze 'switchers' zijn echter dermate blij met hun overstap dat ze hebben aangeven niet meer terug te keren naar de oorspronkelijke werkgever. Aangezien de inlenende bedrijven het loon van deze mensen betaalden, kostte deze maatregel de oorspronkelijke werkgever niets.

\section{Proces}

Het aanvragen van de wtv was niet altijd even eenvoudig. Het feit dat de regeling snel op poten werd gezet, is door bedrijven zeer gewaardeerd, maar de keerzijde van deze snelheid was wel dat zogenaamde 'early adopters' veel hebben moeten uitzoeken en feitelijk nog moesten meehelpen met de uitwerking van de regeling. $00 \mathrm{k}$ de rol van diverse partijen (vakbonden, $0 \mathrm{R}$, etc.) was door de hoge invoersnelheid nog niet voldoende uitgekristalliseerd. Aan de andere kant vonden sommige bedrijven dat de wtv-regeling te weinig rekening hield met de (soms zeer specifieke) opleidingsbehoefte die verschilde van bedrijf tot bedrijf.

Het aanvragen van deeltijd-WW werd als gemakkelijker ervaren door de eenvoudige aanvraagformulieren en door het werken met voorschotten waardoor het geld snel binnen kwam. Overigens hebben lang niet alle bedrijven die voor deeltijd-WW in aanmerking kwamen nadat de wtv-regeling ophield te bestaan, deze ook aangevraagd. Een logische reden hiervoor was dat de omzet van sommige bedrijven al weer in de lift zat. Eén van de bedrijven was echter ook bevreesd voor het mogelijke negatieve psychologische effect van deeltijd-WW want het blijft wel een vorm van WW.

Naast de flexibele schil zijn er nog andere maatregelen die de bedrijven genomen hebben. Vooral het scholen van het personeel is een veelgenoemde maatregel. In 2008 gebeurde dit bij ongeveer een derde van de bedrijven, maar in de tweede helft van 2009 heeft bijna de helft van de bedrijven haar personeel geschoold in de leegloopuren. Ook hebben de bedrijven geprobeerd hun werknemers andere werkzaamheden te laten doen: $47 \%$ van de bedrijven in 2009. Daarnaast worden ook eerder uitbestede 
werkzaamheden nu binnen het bedrijf gehouden. Deze actie is door maar liefst vier van de tien bedrijven in 2009 uitgevoerd.

De regeling werktijdverkorting $(w t v)$ werd in 2008 en vooral in de eerste helft van 2009 gebruikt. In de tweede helft van 2009 heeft $17 \%$ van de bedrijven hun personeel tijdelijk naar huis gestuurd. Het uitlenen van het eigen personeel aan andere bedrijven dat in begin van het jaar 2009 nog door $14 \%$ van de bedrijven werd gedaan, is in de tweede helft van 2009 teruggelopen naar $7 \%$ van de bedrijven.

Positief is wel dat de Metalektro ondanks de crisis nog over voldoende stageplaatsen beschikt. Volgens gegevens van Kenteq van januari 2010 zijn ruim de helft van de beschikbare stageplaatsen en krap een derde van de leerbanen in de metaal en elektrotechniek nog onbezet (zie figuur 2.6 in hoofdstuk 2). In figuur I.5 is wel te zien dat iets meer dan één op de tien bedrijven aangeeft dat ze het aantal stageplaatsen moesten verminderen, maar dit heeft zich nog niet vertaald in een tekort aan stageplaatsen. In de laatste meting van 2009 is ook naar het verminderen van leerbanen gevraagd. $15 \%$ van de bedrijven heeft toen aangegeven dat zij deze zouden moeten verminderen. Uit de cijfers van Kenteq van dezelfde periode blijkt overigens dat deze vermindering van het aantal leerbanen nog niet heeft geleid tot een tekort aan leerbanen in de Metalektro. In hoofdstuk 2 wordt dieper ingegaan op de ontwikkeling van leerbanen en stageplaatsen tijdens de crisis.

\subsection{Werkgelegenheidsontwikkeling}

Sinds een aantal jaren daalt de werkgelegenheid in de Metalektro. Deze licht dalende trend veranderde in 2008 in een lichte stijging van de werkgelegenheid. Hoe de crisis zich vertaalt in de structurele ontwikkeling van de werkgelegenheid in de Metalektro over een langere termijn is met de cijfers van het CBS nog niet na te gaan. De Enquête Beroepsbevolking van 2009 is nog niet gepubliceerd. Het is wel aan te nemen dat de werkgelegenheid door de crisis enigszins afgenomen is. In figuur I.4 is de ontwikkeling van de totale werkgelegenheid in de Metalektro volgens de CBS cijfers te zien. Hierbij is het jaar 200I het basisjaar, waar de werkgelegenheid met een index van Ioo weergegeven wordt. In de volgende jaren daalde de werkgelegenheid in de Metalektro volgens de cijfers van het CBS met 20\%. Van 2004 tot 2008 bleef de werkgelegenheid stabiel, waarna in 2008 zelfs sprake was van een toename in de werkgelegenheid. 


\section{Figuur 1.4}

Ontwikkeling van werkenden in de Metalektro (index, basisjaar: 2001)

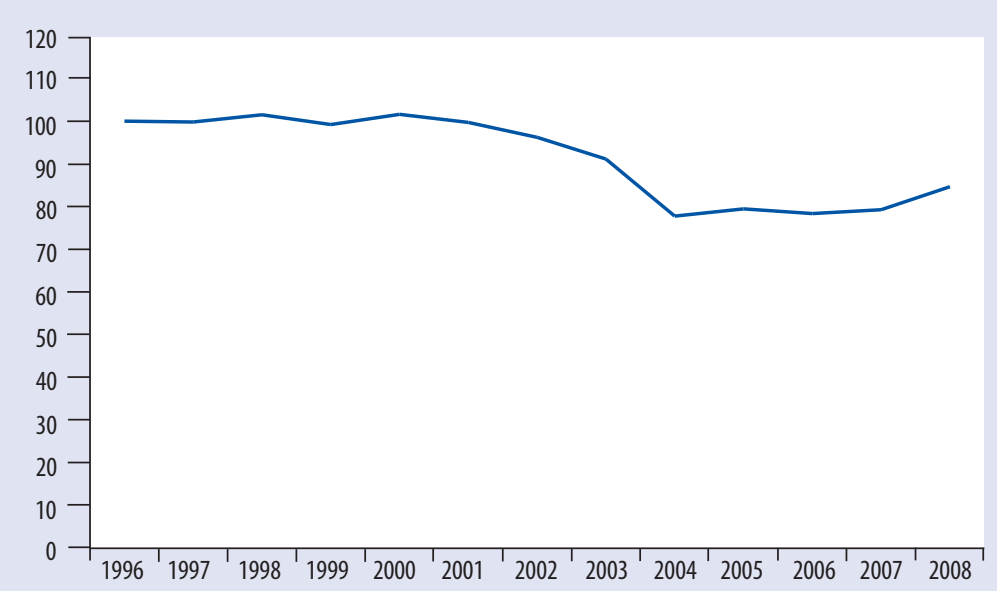

Bron: CBS / Enquête Beroepsbevolking 1996-2008

Zoals ook in hoofdstuk 6 duidelijk wordt heeft de Metalektro een flink aandeel oudere werknemers. In 2008 was $23 \%$ van de werknemers ouder dan 50 . Daar tegenover staat dat $18 \%$ jonger dan 30 is. Van de werkenden heeft bijna de helft (47\%) een opleiding op middelbaar niveau (MBO) gevolgd. Minder dan een derde $(29 \%)$ is laag opgeleid (VMBO of lager), terwijl $24 \%$ hoog opgeleid is (HBO en WO).

\subsection{Innovatie}

De technologische innovaties zijn van groot belang voor de bedrijven in de Metalektro. Ook tijdens de crisis zijn er veel product- en procesinnovaties gerealiseerd. Om zicht op de invloed van de crisis op het innovatiebeleid en de -uitkomsten van de bedrijven te krijgen, hebben de bedrijven in beide metingen over 2009 vragen over producten procesinnovaties beantwoord. $92 \%$ van de bedrijven heeft in 2009 één of meer technologische innovaties geïmplementeerd en het percentage bedrijven dat voor de komende jaren technologische innovaties gepland heeft, is vrijwel even hoog (91\%). Deze cijfers zijn nagenoeg identiek aan die van een half jaar daarvoor. Veel bedrijven verwachten hun geplande technologische innovaties al op korte termijn te realiseren: $84 \%$ van de bedrijven verwacht in 2010 minstens één technologische innovatie te implementeren en $54 \%$ geeft aan dit in de jaren $201 \mathrm{II}-20 \mathrm{I} 4$ te willen doen.

Figuur I.5 geeft de daadwerkelijk gerealiseerde technologische innovaties in 2009 weer en de verwachting voor de innovaties in 20I0. Deze cijfers zijn direct vergelijkbaar met de cijfers van 2009 aangezien alle cijfers betrekkingen hebben op een periode van één jaar. 


\section{Figuur 1.5}

Gerealiseerde innovaties (\% bedrijven)

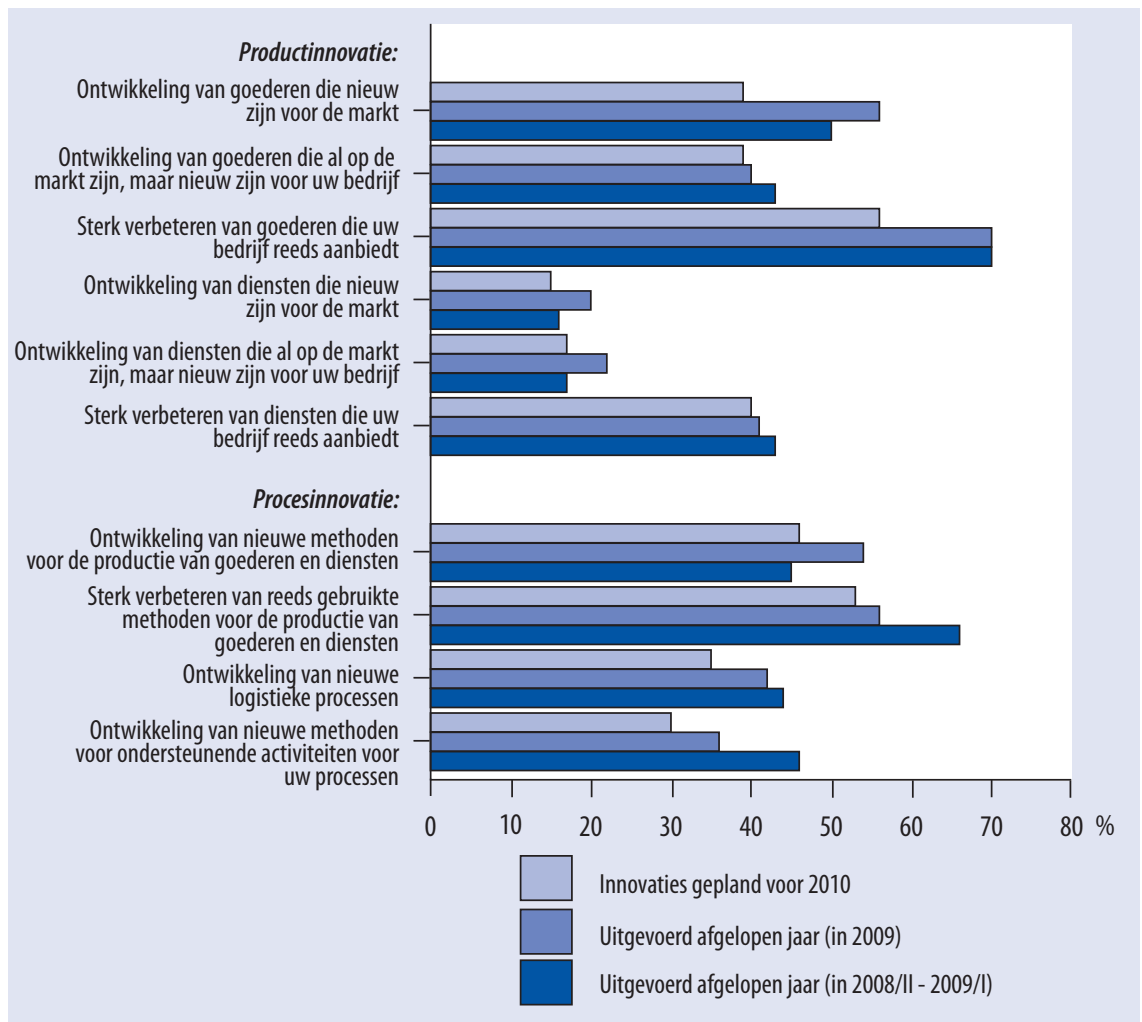

Bron: ROA / Werkgeverspanel Metalektro 2008-2009

Volgens figuur I.5 hebben metalektrobedrijven vooral geïnvesteerd in innovaties ter verbetering van hun huidige producten $(70 \%)$ en het ontwikkelen van compleet nieuwe producten $(56 \%)$. Ongeveer $40 \%$ van de bedrijven richt zich op het doorontwikkelen van bestaande diensten. Maar ook het productieproces wordt door veel bedrijven vernieuwd: ruim 50\% van de bedrijven investeert in de ontwikkeling van geheel nieuwe of doorontwikkeling van bestaande productieprocessen. Op de korte termijn blijft de situatie nagenoeg gelijk: de geplande technologische innovaties voor 2010 laten vrijwel hetzelfde beeld zien als de in 2009 geïmplementeerde technologische innovaties, zij het dat de bedrijven iets voorzichtiger zijn. Indien de voorspelling van de verwachte innovaties voor 2010 uitkomt, dan zullen relatief minder bedrijven product- en procesinnovaties uitvoeren dan in 2009. Dit zou het gevolg kunnen zijn van verminderde investeringen tijdens de crisis. 


\section{Figuur 1.6}

Verwachte innovaties (\% bedrijven, voor de komende vijf jaar)

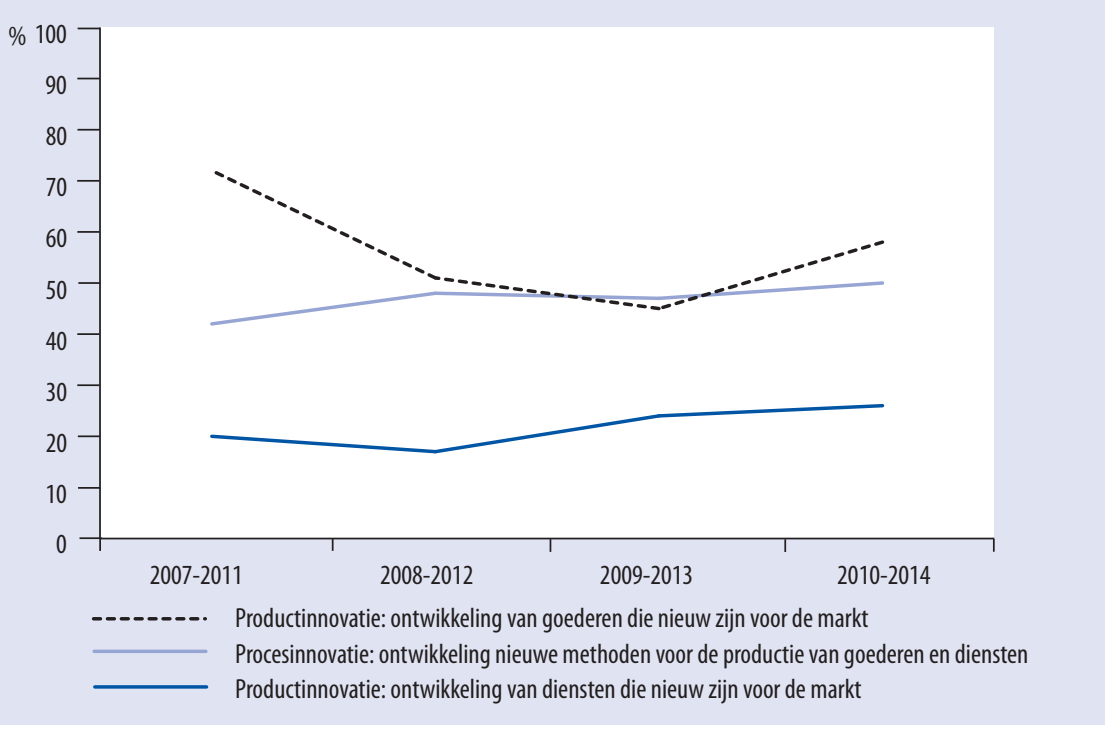

Bron: ROA / Werkgeverspanel Metalektro 2006-2009

Heeft de crisis tot een verandering in het innovatiebeleid van metalektrobedrijven geleid? Om deze vraag te beantwoorden geeft figuur 1.6 voor drie categorieën van innovaties de vijfaarsverwachtingen uit de jaren 2006, 2007, 2008 en 2009 weer. Hierbij is gekozen voor het ontwikkelen van goederen die nieuw zijn voor de markt, diensten die nieuw zijn voor de markt en procesinnovaties. Op basis van de getoonde vijfjaarsverwachtingen lijkt de conclusie gerechtvaardigd dat de crisis geen invloed heeft gehad op het innovatiebeleid in de Metalektro. De structurele ontwikkeling over de laatste jaren is dat bedrijven veel verwachten op het gebied van nieuwe diensten. Daarnaast neemt het percentage bedrijven dat nieuwe methoden voor het productieproces verwacht ook gestaag toe. Productinnovaties van producten die nieuw zijn voor de markt ondergaan wat meer fluctuaties. De daling van de voorgaande jaren is veranderd in een opwaartse lijn. De bedrijven zijn inmiddels optimistischer: bijna $60 \%$ van de bedrijven verwacht inmiddels in de komende vijf jaar een product op de markt te brengen dat nieuw is voor de markt. 


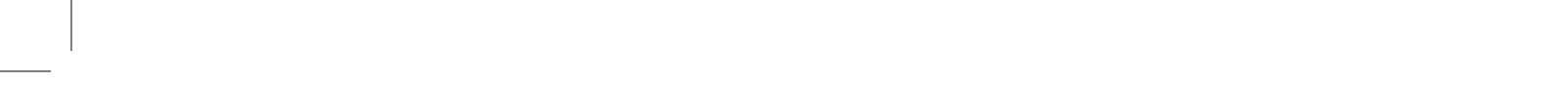




\section{Metalektro in het crisisjaar 2009}

In dit hoofdstuk zullen de ontwikkelingen van de werkgelegenheid en de verwachtingen van bedrijven over de crisis worden geanalyseerd. Hiervoor worden data uit de Quickscan, externe gegevens afkomstig van het pensioenfonds PME en informatie over stage- en leerplekken van Kenteq gebruikt. De eerste paragraaf is volledig gewijd aan enkele indicatoren die afkomstig zijn uit de Quickscan. In de tweede paragraaf staan de data van het pensioensfonds PME centraal en in de derde paragraaf wordt ingegaan op de leer-en stageplekken in de Metalektro.

\subsection{Quickscan-monitor}

Sinds 2009 is de Quickscan uitgebreid met een aantal monitorvragen. Hiermee wordt een bedrijf gevraagd een inschatting te geven van de verwachte groei of krimp van de werkgelegenheid, de verandering in het aantal vacatures en de tijd dat vacatures open blijven staan. Doordat de Quickscan elke twee maanden aan de bedrijven wordt voorgelegd, kan een betere en actuelere inschatting gegeven worden over de daadwerkelijke en de verwachte ontwikkeling van de werkgelegenheid en vacatures in de Metalektro.

In figuur 2.I is de indicator ${ }^{\mathrm{I}}$ voor de werkgelegenheid op basis van de Quickscan en de twee halfjaarlijkse metingen weergegeven. Duidelijk is te zien dat het merendeel van de bedrijven in 2009 een negatieve werkgelegenheidsontwikkeling meemaakt. De figuur geeft de feitelijke ontwikkeling weer met behulp van de grijze oppervlakte die boven of onder de nullijn kan liggen. Gezien deze voor het gehele jaar onder de nullijn lag, geeft de meerderheid van de bedrijven aan een afname van het aantal werknemers mee te maken. Deze gegevens zijn telkens gevraagd voor afgelopen periode van twee maanden voor de enquête. Tegelijkertijd is ook naar een inschatting voor de

I. In figuur 2.I en 2.2 wordt de informatie uit alle Quickscans van het afgelopen jaar en de halfjaarlijkse metingen gecombineerd. De informatie is vertaald naar een indicator, die het aantal bedrijven met een positieve ontwikkeling minus het aantal bedrijven met een negatieve ontwikkeling gedeeld door het totaal aantal bedrijven weergeeft. De indicator kan maximaal een waarde van I aannemen wat betekent dat alle bedrijven een positieve ontwikkeling meemaken of voor de toekomst verwachten. Een waarde van -I betekent dat alle bedrijven een negatieve ontwikkeling meemaken of verwachten. 
toekomstige ontwikkeling voor de komende periode van twee maanden te maken. Deze inschattingen worden in de figuur met een stippellijn weergegeven.

Figuur 2.1

Indicator werkgelegenheid (gerealiseerd en verwacht)

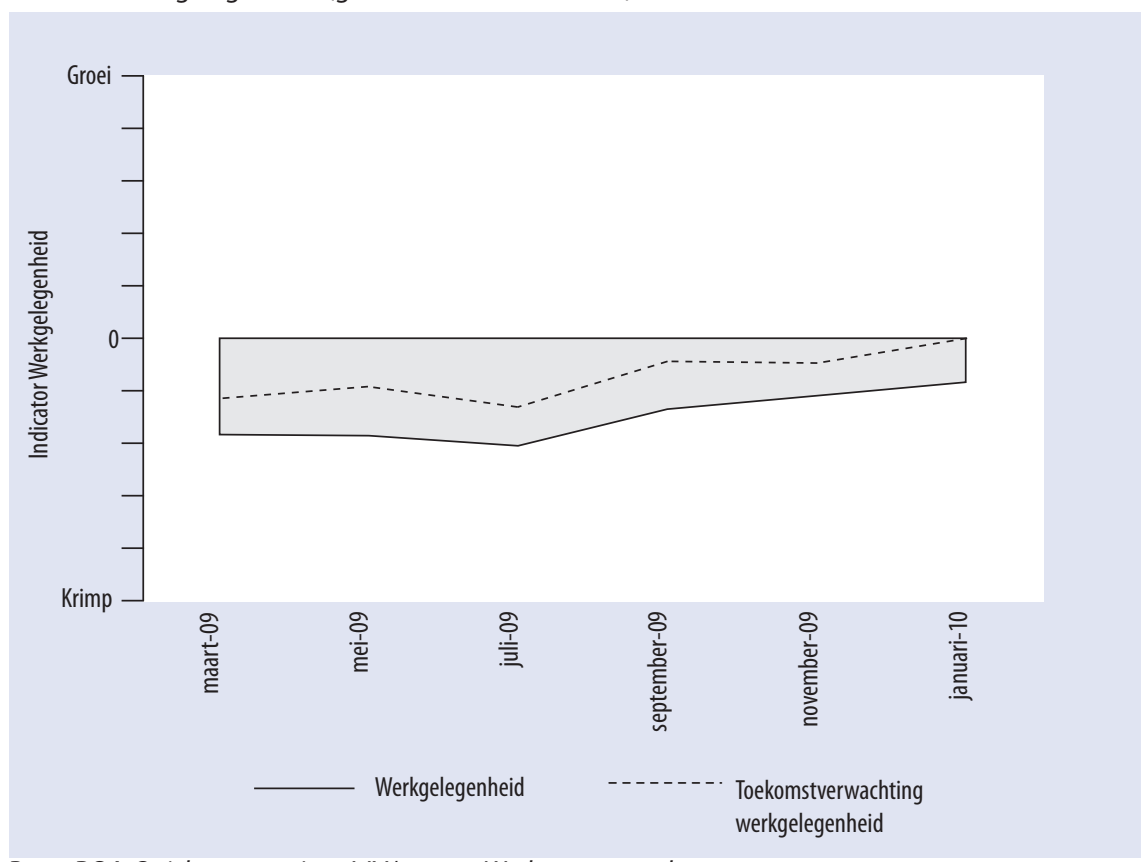

Bron: ROA Quickscanmonitor, I-IV/2009 + Werkgeverspanel 2009

Volgens figuur 2.I was de werkgelegenheidsontwikkeling in 2009 ronduit slecht. Veel bedrijven hebben hun personeelsbestand verminderd. Deze negatieve werkgelegenheidsontwikkeling heeft zich vooral in de eerste helft van 2009 gemanifesteerd. Vanaf september 2009 is de krimp echter afgenomen. Bij de verwachtingen van de bedrijven is dit nog beter te zien. De stippellijn met de verwachtingen volgt tot de zomer immers de feitelijke ontwikkeling, zij het dat bedrijven over het algemeen iets optimistischer over de toekomst waren dan over het verleden. Vanaf de septembermeting lopen de verwachtingen richting de nullijn, zodat er in januari 2010 zelfs bijna een evenwicht is tussen bedrijven die krimp verwachten en bedrijven die in de komende maanden een stijgende werkgelegenheid verwachten.

Figuur 2.2 laat een soortgelijke figuur als figuur 2.I zien, maar nu met betrekking tot de ontwikkeling van de vacatures. Het grijze gebied laat de toename (indien boven de nullijn) of de afname van de vacatures (indien onder de nullijn) zien. In het afgelopen jaar is het aantal openstaande vacatures duidelijk verminderd. Net als in figuur 2.I is naast de feitelijke ontwikkeling ook de toekomstverwachting weergegeven. Ook hier is te zien dat de toekomstverwachtingen van bedrijven over het toenemen van 
de vacatures in 2009 optimistischer waren dan de feitelijke ontwikkeling. Begin 2010 wordt een keerpunt bereikt: het aantal bedrijven dat een vermindering van het aantal vacatures verwacht is dan ongeveer gelijk aan het aantal dat een toename verwacht.

\section{Figuur 2.2}

Indicator vacatures (gerealiseerd en verwacht)

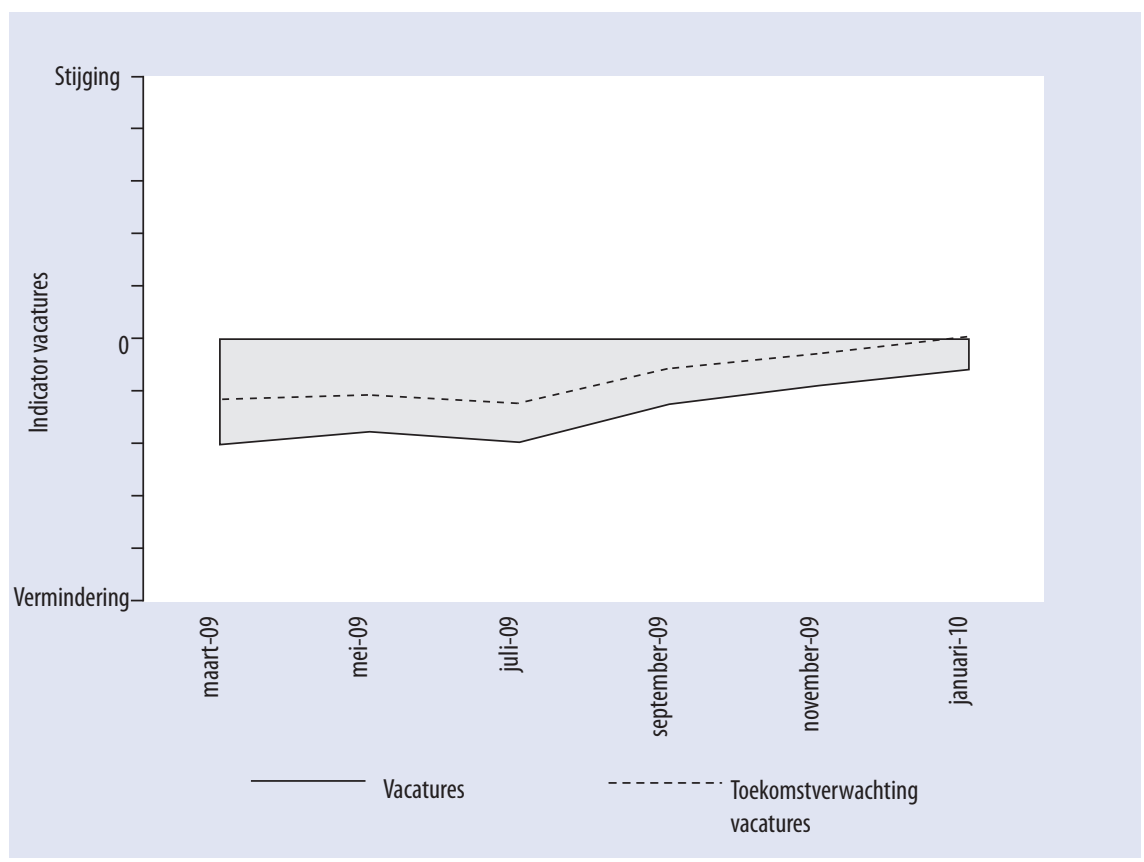

Bron: ROA Quickscanmonitor, I-IV/2009 + Werkgeverspanel 2009

Naast het aantal vacatures is het natuurlijk ook van belang hoe eenvoudig of hoe snel een bedrijf zijn vacatures weet in te vullen. In een ruime arbeidsmarkt is er veel aanbod van werkenden en vacatures zullen niet lang open staan. Op een krappe arbeidsmarkt is het juist andersom: er zijn weinig werkzoekenden en veel vacatures. Dit vertaalt zich in langer openstaande vacatures. Figuur 2.3 laat zien dat de vacatureduur over de gehele tijd laag blijft. Het percentage bedrijven zonder enkele vacature kent zijn hoogste stand in de juli 2009 meeting. In het verloop van 2009 daalt dit percentage. 


\section{Figuur 2.3}

Gemiddelde vacature duur en percentage bedrijven zonder vacatures

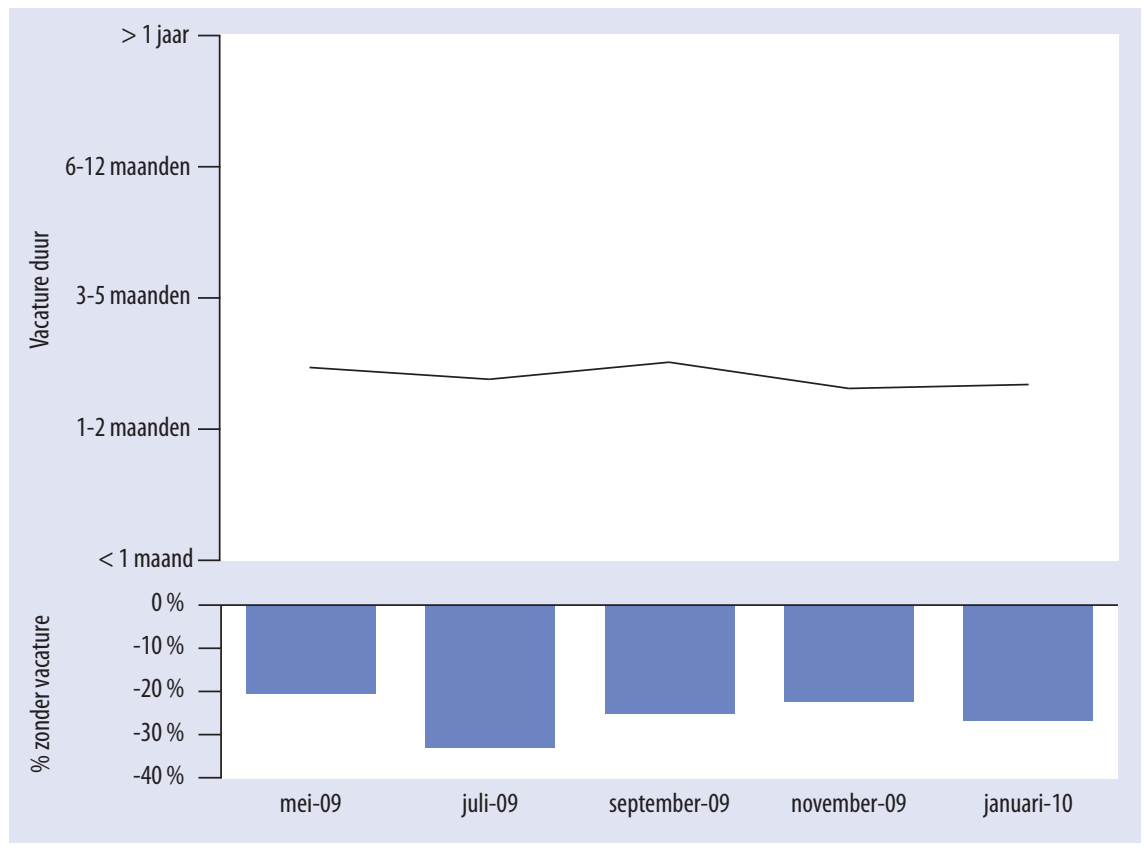

Bron: ROA Quickscanmonitor, II-IV/2009 + Werkgeverspanel 2009

\subsection{Werknemers aangesloten bij PME}

De ontwikkeling van het aantal werknemers in de Metalektro kan ook worden geschat via data van het pensioensfonds. Het Pensioensfonds van de Metalektro (PME) omvat alle bedrijven van de Metalektro die geen eigen pensioensfonds hebben. Volgens het PME jaarverslag van 2008 waren er 62 bedrijven met vrijstelling. ${ }^{2}$ De data is gebaseerd op de administratieve gegevens van het PME, waarbij de eerste observatie van I december 2008 is en de laatste van I november 2009. Het betreft doorsnee gegevens op bepaald tijdstippen waar telkens twee of drie maanden tussen zit.

Zoals figuur 2.4 laat zien, daalt het aantal PME-deelnemers tussen december 2008 en november 2009 met $8 \%$. De figuur geeft ook de leeftijdsverdeling weer: een redelijk kleine groep is jonger dan 30 jaar. Deze groep daalt weliswaar in absolute aantallen, maar hun werkgelegheidsaandeel stijgt over de getoonde periode. Het grootste deel van de PME-deelnemers valt in de leeftijdscategorie van 30 tot en met 49 jaar. Ook

2. Hieronder vallen ook grote bedrijven zoals Corus en Philips. De aantallen deelnemers in PME zijn dus niet het totaal van de Metalektro werknemers. Wel geven zij een goede inschatting van de ontwikkeling van de werkgelegenheid in de Metalektro. 
deze groep neemt in absolute omvang af, maar ziet haar aandeel stijgen. Dit komt doordat het aantal oudere deelnemers van 50 jaar of ouder nog harder gedaald is.

Figuur 2.4

Ontwikkeling deelnemers PME per leeftijdsgroep

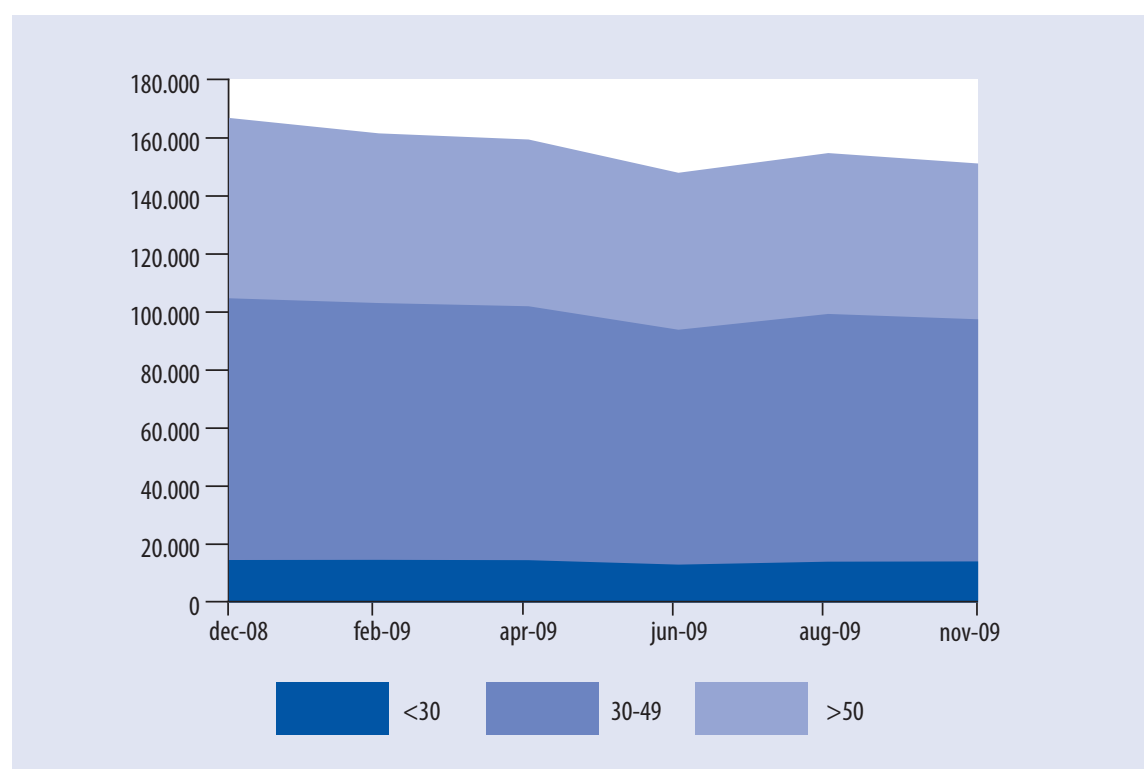

Bron: PME 2008-2010, bewerking ROA

Op basis van de gegevens van het PME kan ook de verhouding tussen het aantal parttime en fulltime PME-deelnemers in kaart worden gebracht. Het aandeel parttimers - volgens het PME - is redelijk stabiel en omvat rond de I0\% van alle aangesloten werknemers. Deze verhouding is in 2009 nauwelijks veranderd. Ook de regionale spreiding van de bij het PME aangesloten bedrijven is in 2009 vrij stabiel, al is de regio Zuid iets sterker door de crisis getroffen dan de andere regio's.

Figuur 2.5 laat zien hoe de werkgelegenheid van verschillende inkomensgroepen is veranderd. De laagste inkomensgroep heeft betrekking op PME-deelnemers met een bruto maandsalaris dat onder de $€ 2000$ ligt. De middengroep bevat de deelnemers met een bruto maandsalaaris van $€ 2000$ tot $€ 3500$. Tweederde van alle PME-deelnemers valt in deze salariscategorie. De laatste groep zijn de PME-deelnemers met een inkomen van meer dan $€ 3500$ per maand. Ook al verandert de onderlinge verhouding van de inkomensgroepen per observatieperiode, kan wel gesteld worden dat de laagste en midden-inkomensgroepen het meest geraakt zijn door de crisis. De groep met het hoogste inkomen stijgt licht, terwijl in beide andere groepen minder mensen in dienst blijven. Dit ligt in de lijn der verwachting aangezien bedrijven vooral hun kernpersoneel hebben vastgehouden. Deze werknemers behoren door hun opleiding 
en werkervaring zeer waarschijnlijk tot een hogere inkomensgroep dan de werknemers in de flexibele schil.

Figuur 2.5

Verdeling PME aangesloten werknemers bij inkomen (\% werknemers)

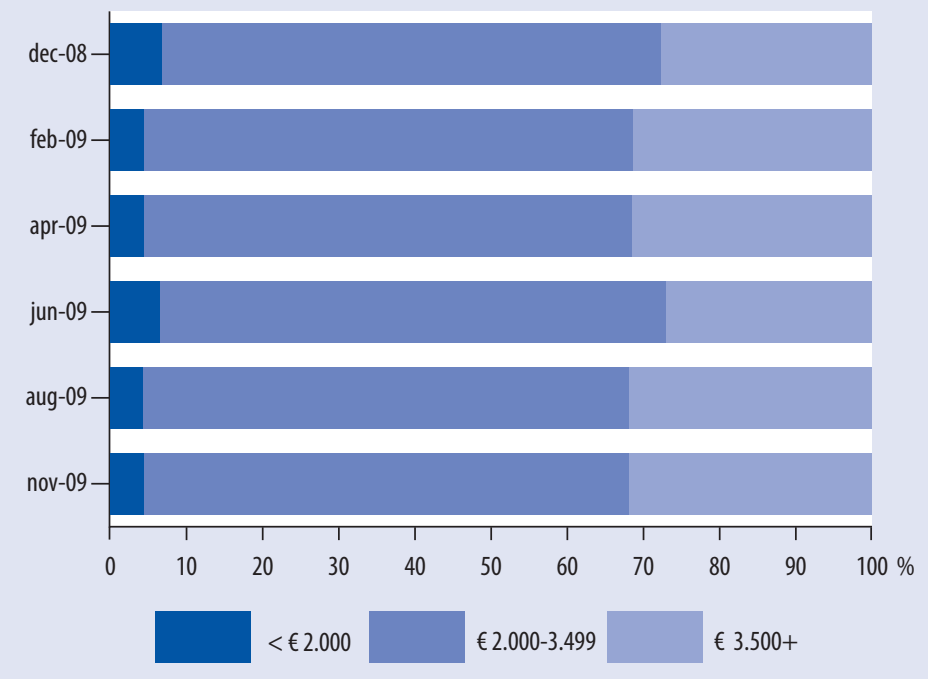

Bron: PME 2008-2010, bewerking ROA

\subsection{Leerbanen en Stageplekken}

Leerbanen en stageplekken zijn van cruciaal belang om de benodigde werknemers voor de toekomst op te leiden. Zoals we in hoofdstuk 7 zullen laten zien, zal in de komende jaren de aanwas van nieuwe werknemers hard nodig zijn om toekomstige lacunes aan vakkrachten te vullen. Daarom is het van groot belang dat de opleiding in de Metalektro op peil blijft en dat er voldoende leerbanen en stagemogelijkheden bestaan. Het valt echter niet mee om deze opleidingsplekken beschikbaar te houden als er onvoldoende werk voor het zittende personeel is. In hoofdstuk I werd al als een van de crisismaatregelen genoemd dat bedrijven minder stageplaatsen (I4\%) en leerbanen ( $15 \%)$ aanbieden.

Figuur 2.6 toont de ontwikkeling van het beschikbare aantal leerbanen voor de Metalektro. Deze cijfers afkomstig van telefonische enquêtes die Kenteq onder een steekproef van bedrijven gehouden heeft, ${ }^{3}$ laten zien dat het aantal leerbanen, vooral in de metaal, terugloopt. De stippellijnen in figuur 2.6 laten echter

3. Kenteq maakt geen onderscheid tussen klein- en grootmetaal. De cijfers zijn dus niet direct van toepassing voor de Metalektro. 
zien dat dit nog niet tot een tekort aan leerbanen heeft geleid. Want hoewel het percentage onbezette leerbanen in zowel Elektro als Metaal in 2009 licht gedaald is, is nog altijd ruim $30 \%$ van de leerbanen onbezet. Er zijn dus op het moment van schrijven van dit rapport nog voldoende leerbanen beschikbaar.

\section{Figuur 2.6}

Ontwikkeling en benutting van het aantal leerbanen technische sector

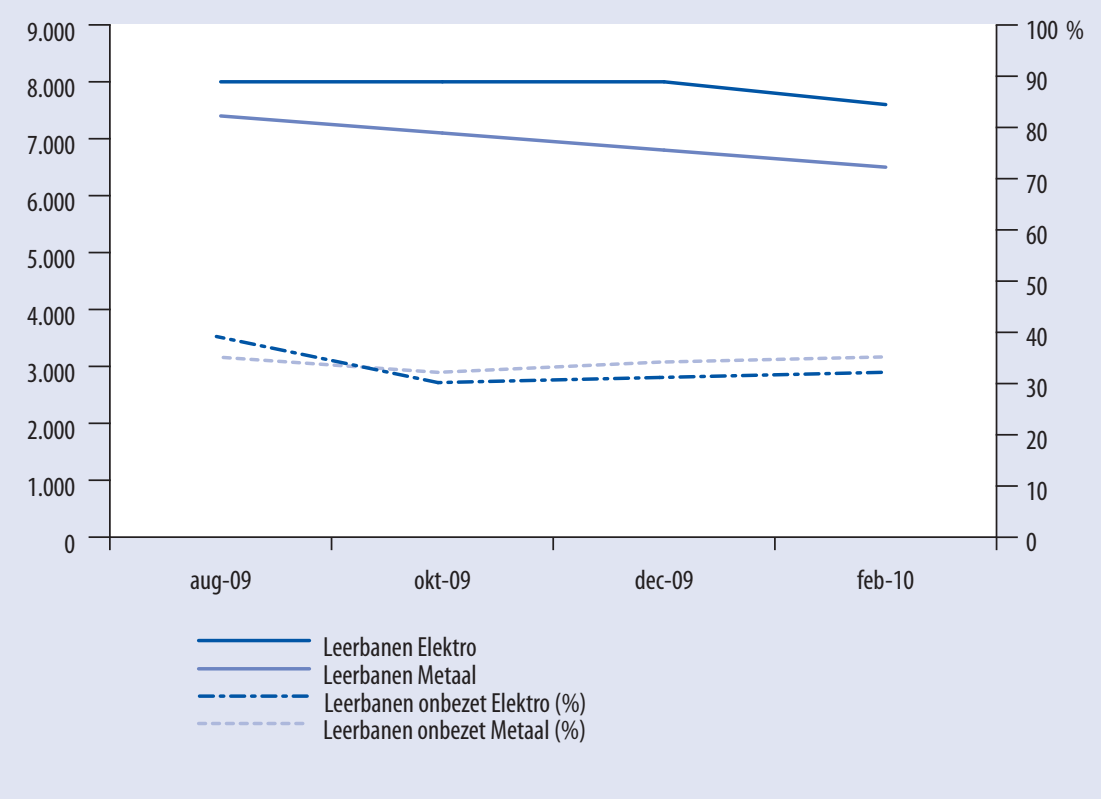

Bron: Kenteq: Kentallen 2009-2010, Nummer 1-4

Een soortgelijk beeld kan geschetst worden als men naar de beschikbare stageplekken kijkt. Volgens Kenteq loopt dit weliswaar terug van 8.000 (Elektro) en 7.800 (Metaal) in augustus 2009 tot 6.400 en 6.000 stageplekken in februari 20I0, maar over de gehele periode blijft rond de helft van deze stageplekken onbezet.

\section{Stageplaatsen: tussen beeld en werkelijkheid}

Diverse bedrijven zien een grote discrepantie tussen het in de media geschetste beeld van "veel leerlingen kunnen geen leerwerkplek of stage vinden door de crisis" en hun eigen ervaringen dat ze wel plekken hebben, maar daar geen (geschikte) leerlingen voor kunnen vinden. Het is dus maar de vraag in hoeverre het erg is dat $58 \%$ van de bedrijven in een Quickscan aangeeft het aantal stageplekken voor scholen te hebben teruggebracht vanwege de crisis. 


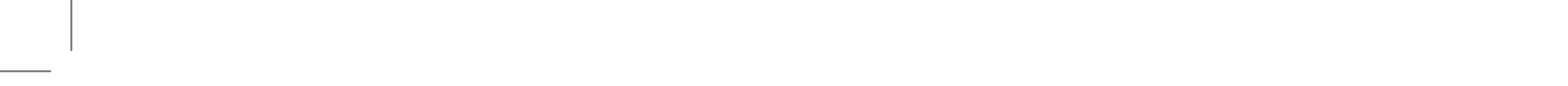




\section{Arbeidsmarktontwikkelingen in 2009}

In dit hoofdstuk wordt een beeld geschetst van de recente arbeidsmarktontwikkelingen in de Metalektro zoals deze voortkomen uit de enquête onder de panelleden. De personeelsuitstroom in de Metalektro in 2009 komt aan bod in paragraaf 3.1 gevolgd door de instroom van nieuwe medewerkers in paragraaf 3.2. De combinatie van in-en uitstroom wordt beschreven in paragraaf 3.3 zodat een beeld verkregen wordt van de huidige werkgelegenheidsontwikkelingen in de Metalektro. In paragraaf 3.4 staan we ten slotte stil bij de mate waarin de bedrijven in de Metalektro gebruik maken van flexibele arbeidskrachten.

\subsection{Personeelsuitstroom in de Metalektro}

Er zijn in 2009 behoorlijk wat werknemers vertrokken bij de bedrijven in de Metalektro. Vooral in de eerste helft van 2009 stroomden er veel werknemers uit: in totaal maar liefst 6.270. In de tweede helft van het jaar nam de uitstroom weer af tot zo'n 4.480 werknemers. Al met al stroomden er in 2009 dus I0.750 werknemers uit bij de bedrijven in de Metalektro. Ter vergelijking: in 2008 waren dit er nog ongeveer 9.500.

Figuur 3.I laat zien dat het grootste deel van de vertrokken werknemers werkzaam was in de uitvoerende technische functies. Aangezien deze functiecategorie ook veruit het vaakst voorkomt binnen de metalektrobedrijven spreekt dit voor zich. In de eerste helft van 2009 vertrokken maar liefst 3.790 werknemers uit de uitvoerende technische functies. Deze werknemers vertrokken bij $65 \%$ van de bedrijven. $35 \%$ van de bedrijven had dus zelf tijdens de zwaarste periode van de economische crisis geen personeelsuitstroom in deze functies. In de tweede helft van het jaar liep de uitstroom van uitvoerende technici weer terug tot zo'n 2.500 werknemers, evenveel als in de tweede helft van 2008. 60\% van de bedrijven in de Metalektro sprak van uitstroom onder uitvoerende technici.

Ook in de ondersteunende functies was de uitstroom in 2009 hoog. In de eerste helft van dat jaar had respectievelijk $36 \%$ en $4 \mathrm{I} \%$ van de bedrijven uitstroom in de technische en niet-technische ondersteunende functies. Het ging hierbij in totaal om 720 technici en 1.070 medewerkers in niet-technische ondersteunende functies. In 
de tweede helft van 2009 was de uitstroom iets teruggelopen: $25 \%$ en $30 \%$ van de metalektrobedrijven hadden in totaal nog eens 560 en 880 vertrekkende werknemers in beide soorten ondersteunende functies. Deze aantallen zijn vergelijkbaar met de uitstroom uit deze functies in 2008. Bij ruim één op de vijf bedrijven in de Metalektro vertrok er in beide helften van 2009285 werknemers uit leidinggevende technische functies. In 2008 stroomden er zowel in de eerste als in de tweede helft van het jaar nog 340 leidinggevende technici uit. Bij $15 \%$ van de bedrijven vertrokken er in de eerste helft van 2009 technisch opgeleide verkopers (I85) en niet-technische leidinggevenden (220). In de tweede helft van het jaar was dit nog het geval bij zo'n I2\% van de bedrijven. Zij zagen nog eens 155 technisch opgeleide verkopers en Ioo niet-technische leidinggevenden uitstromen.

Figuur 3.1

Totaal aantal vertrokken werknemers en aandeel bedrijven met vertrokken werknemers per functiecategorie

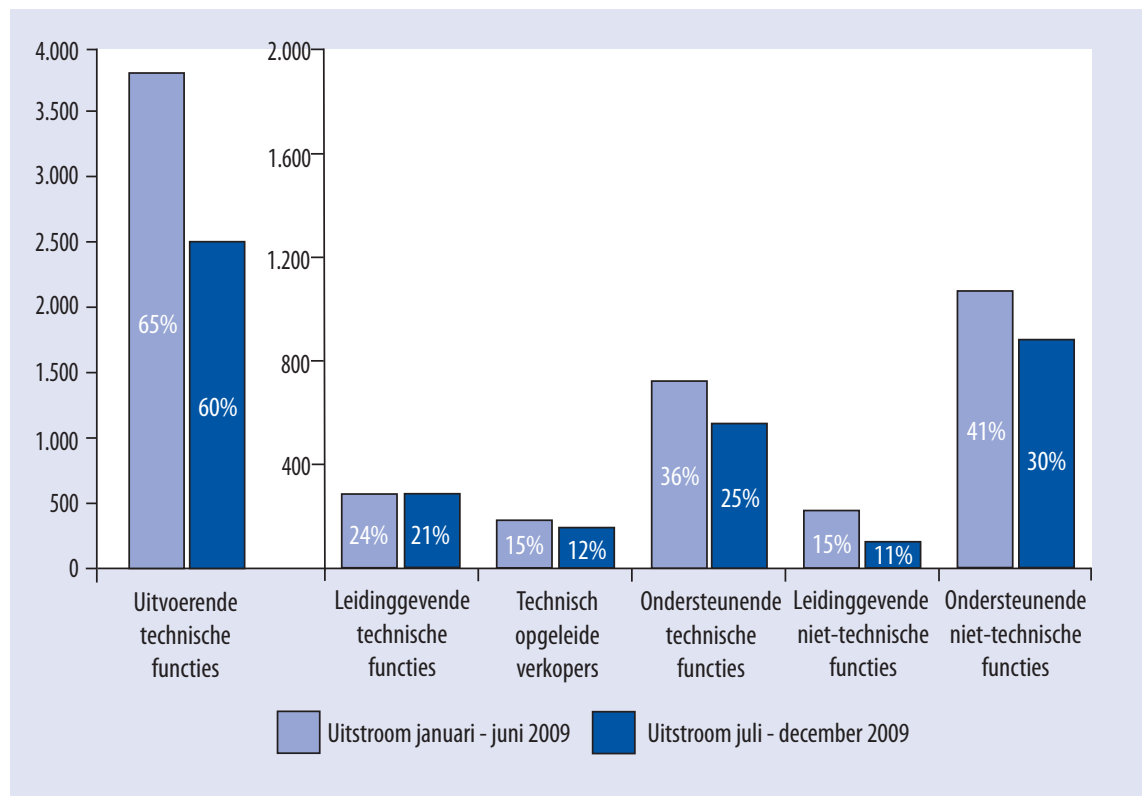

Bron: ROA / Werkgeverspanel Metalektro 2009

In figuur 3.2 wordt de ontwikkeling van de uitstroom in de verschillende functiecategorieën in de laatste vijf jaar weergegeven. ${ }^{4}$ Met uitzondering van de uitvoerende technische werknemers en ondersteunende niet-technische werknemers nam de uitstroom in alle functiecategorieën tussen 2008 en 2009 af. In 2005 en 2006 stroomden er ongeveer 4.400 uitvoerende technici uit bij de metalektrobedrijven. In 2007 daalde dit naar 3.650, om in de afgelopen twee jaren weer te stijgen tot 6.290 in 2009 . Eenzelfde

4. Voor 2005 werden er andere functiecategorieën in de Arbeidsmarktmonitor Metalektro onderscheiden, deze zijn niet direct vergelijkbaar met de functiecategorieën die sinds 2005 gehanteerd worden. 
patroon is waar te nemen bij de ondersteunende niet-technische functies. Tussen 2005 en 2007 halveerde de uitstroom van 1.900 naar 950 om in 2009 weer te stijgen tot $\mathrm{I} .950$ werknemers. Bij de leidinggevende en ondersteunende technische functies en de technische opgeleide verkopers bleef de uitstroom tussen 2005 en 2009 redelijk constant. De uitstroom onder de leidinggevende technici was het laagst in 2007 met 440 en het hoogst in 2008 met 665 . Onder de ondersteunende technici was de uitstroom in 2005 met $\mathrm{I} .690$ het hoogst en in 2006 met $\mathrm{I} .020$ het laagst.

Figuur 3.2

Ontwikkeling personeelsuitstroom per functiecategorie

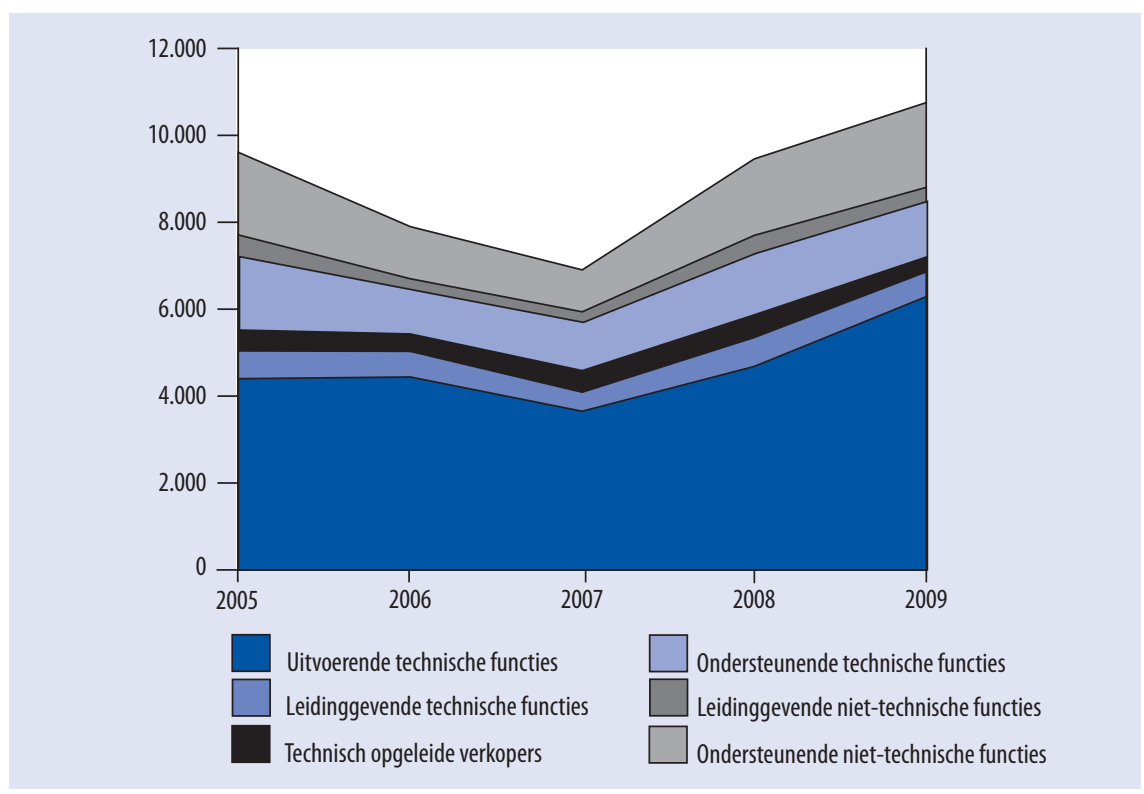

Bron: ROA / Werkgeverspanel Metalektro 2005-2009

\subsection{Personeelsinstroom in de Metalektro}

In deze paragraaf wordt ingegaan op zowel de totale personeelsinstroom in 2009 als de ontwikkeling van de instroom per functiecategorie tussen 2005 en 2009 . In figuur 3.3 wordt de totale instroom per functiecategorie weergegeven, aangevuld met het percentage bedrijven dat instroom in deze functiecategorieën had. De totale personeelsinstroom was in 2009 erg laag. In de eerste helft van 2009 namen de bedrijven in de Metalektro in totaal 2.865 werknemers in dienst. In de tweede helft werden er 2.180 werknemers aangenomen. Over heel 2009 gezien stroomden er bij de bedrijven 5.045 werknemers in. Dit is minder dan de helft van de instroom in 2008. In combinatie met de hoge uitstroom van bijna II.০oo is de werkgelegenheid in de Metalektro dus fors afgenomen in 2009 . 


\section{Figuur 3.3}

Totaal aantal nieuw aangenomen werknemers en aandeel bedrijven met nieuwe werknemers per functiecategorie

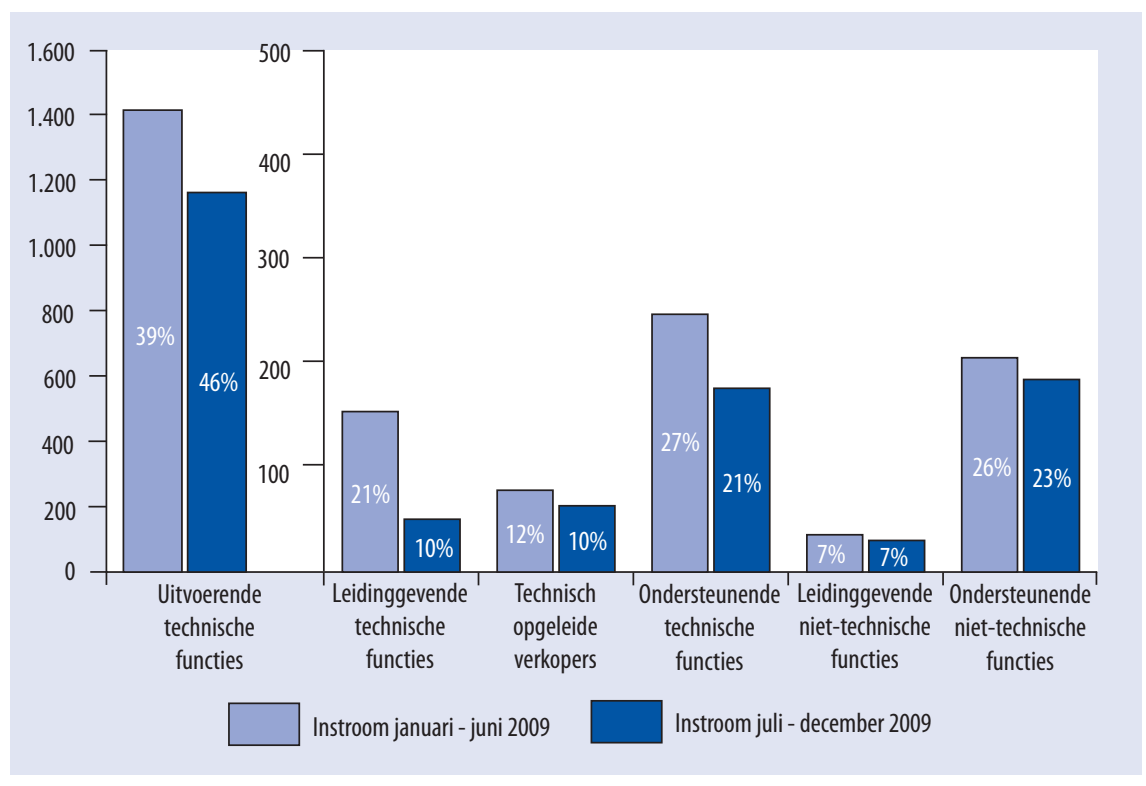

Bron: ROA / Werkgeverspanel Metalektro 2009

Zoals verwacht concentreert de instroom zich op uitvoerende technische functies. $39 \%$ van de metalektrobedrijven nam in de eerste helft van 2009 in totaal I.4I5 nieuwe werknemers voor deze functies in dienst. In de eerste helft van 2008 waren dit er nog 3.600. In de tweede helft van 2009 had een iets groter deel van de bedrijven instroom van uitvoerende technici: $46 \%$ van de bedrijven nam in totaal I.I6o werknemers in dienst. Ter vergelijking: in de tweede helft van 2008 waren dit er 2.500.

Ook in de andere functiecategorieën was de instroom in 2009 laag. In de ondersteunende functies was de instroom relatief nog het hoogst. In de eerste helft van 2009 had $27 \%$ van de bedrijven nieuwe instroom in de technische- en niet-technische ondersteunende functies. Het ging hierbij in totaal om 500 technische- en 415 niet-technische ondersteunende medewerkers. In de tweede helft van 2009 was de instroom nog iets verder teruggelopen: ongeveer $22 \%$ van de metalektrobedrijven nam in beide soorten ondersteunende functies nieuwe medewerkers in dienst. Fors minder dan de instroom in deze functies in 2008. Bij één op de vijf bedrijven in de Metalektro werden in de eerste helft van 2009 in totaal 310 nieuwe leidinggevende technici in dienst genomen. In de tweede helft van 2009 had nog maar één op de tien bedrijven nieuwe instroom in deze functies. $\mathrm{Zij}$ namen gezamenlijk nog Ioo leidinggevende technici in dienst. Slechts weinig bedrijven namen in 2009 nieuwe technisch opge- 
leide verkopers en niet-technische leidinggevenden aan. Het ging hier in totaal om 285 nieuwe technisch opgeleide verkopers en 135 nieuwe niet-technische leidinggevenden.

\section{Figuur 3.4}

Ontwikkeling personeelsinstroom per functiecategorie

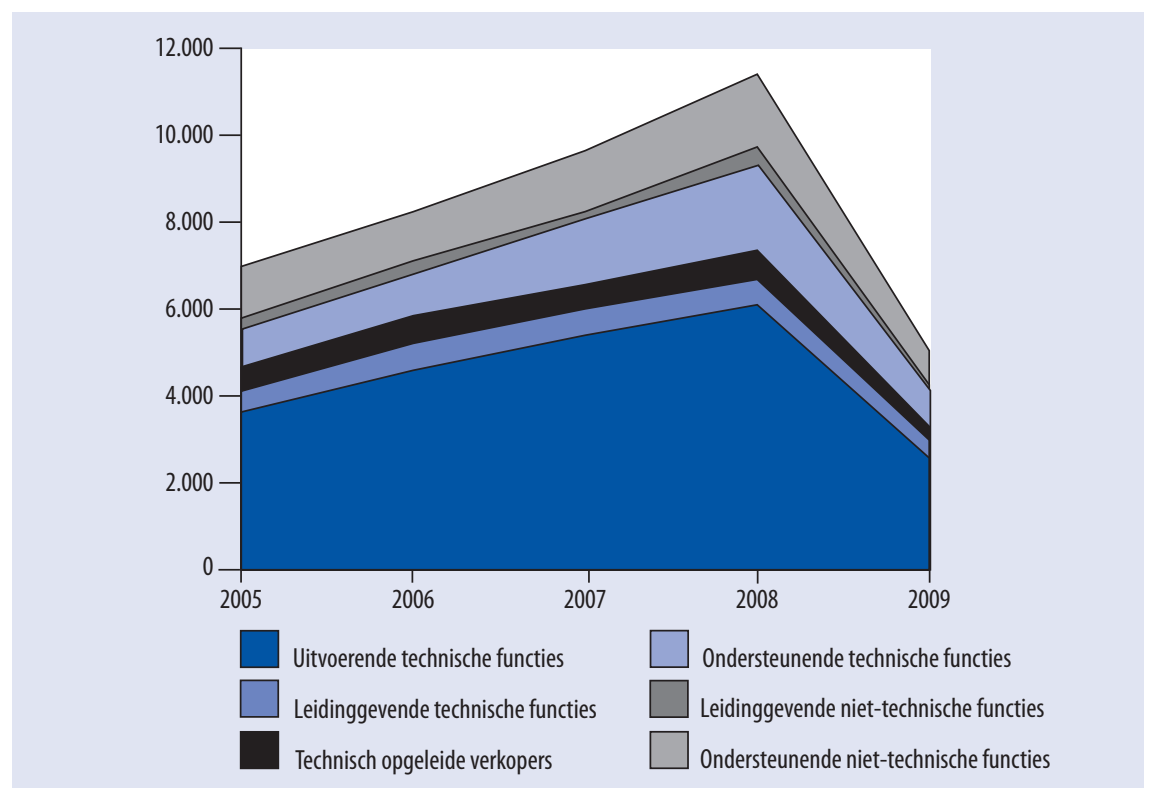

Bron: ROA / Werkgeverspanel Metalektro 2005-2009

In figuur 3.4 wordt de ontwikkeling van de personeelsinstroom tussen 2005 en 2009 per functiecategorie weergegeven. Tussen 2005 en 2008 groeide de personeelsinstroom in uitvoerende technische functies gestaag van 3.630 tot 6.100. In 2009 daalde de instroom echter naar het laagste niveau van de afgelopen vijf jaar: 2.575. Bij zowel de technische- als de niet-technische ondersteunende functies is een soortgelijke trend waarneembaar. Een forse toename tussen 2005 en 2008 gevolgd door een sterke afname in 2009 . Ook bij de andere functiecategorieën was de instroom in 2009 de laagste van de afgelopen vijf jaar. Het aantal nieuwe leidinggevende niet-technische functies varieerde van jaar tot jaar, terwijl het aantal nieuwe technisch opgeleide verkopers tussen 2005 en 2008 redelijk constant bleef om vervolgens meer dan te halveren in 2009. Het aantal nieuwe technische leidinggevenden ten slotte, bleef gedurende de hele periode ongeveer even hoog ondanks een lichte daling in 2009. 


\section{Figuur 3.5}

Ontwikkeling totale personeelsinstroom en -uitstroom

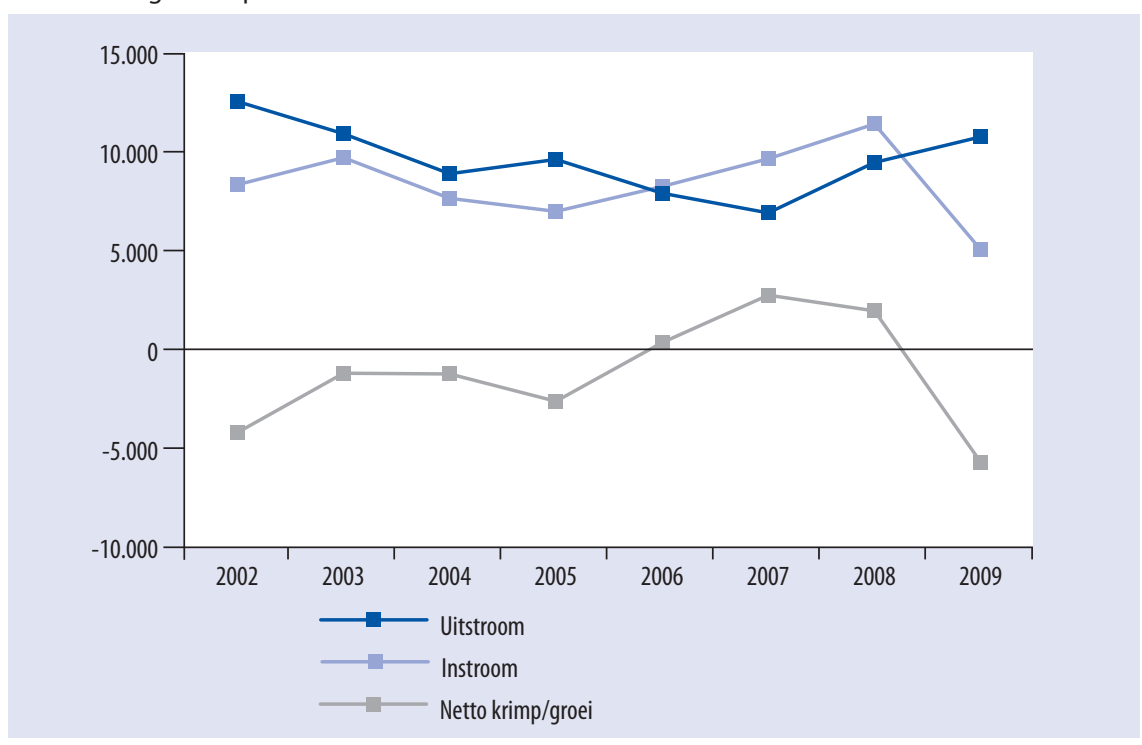

Bron: ROA / Werkgeverspanel Metalektro 2002-2009

In figuur 3.5 wordt de ontwikkeling van de totale instroom en uitstroom per jaar weergegeven, aangevuld met de hieruit volgende groei dan wel krimp van het personeel. De totale personeelsuitstroom was in 2002 op het hoogste niveau sinds het bestaan van de Arbeidsmarktmonitor Metalektro: Toen stroomden maar liefst 12.545 werknemers uit bij de bedrijven in de Metalektro. Met uitzondering van een stijging in 2005 volgde sindsdien een dalende trend die zich doorzette tot en met 2007. Toen bedroeg de totale personeelsuitstroom nog 6.905. In de afgelopen twee jaren, en dan vooral in 2009, steeg de uitstroom sterk tot 10.750.

$\mathrm{Na}$ een stijging tussen 2002 en 2003 daalde de instroom, waarschijnlijk onder invloed van de toenmalige economische recessie, tussen 2003 en 2005 van 9.700 tot 6.980 werknemers. Vervolgens steeg de instroom van nieuwe medewerkers vrij hard tot en met 2008 , toen de totale nieuwe instroom II.40o bedroeg. Daarmee werd de hoogste instroom sinds het bestaan van de monitor bereikt. Zoals eerder in deze paragraaf al beschreven, zakte de instroom in het afgelopen jaar echter in elkaar tot 5.045 personen: minder dan de helft van de instroom.

Al met al kromp het totale personeelsbestand tussen 2002 en 2005 gevolgd door drie jaren van groei. In het afgelopen jaar was er weer en sterke krimp. Over de volledige periode van 2002 tot en met 2009 stroomden er bijna Io.000 werknemers meer uit dan in. 


\section{Beroepspraktijkvormingsplaatsen aanbieden heeft ook voordelen}

Het aanbieden van stageplaatsen, leerbanen en afstudeeropdrachten door metalektrobedrijven vraagt een behoorlijke inzet van tijd en geld. De kosten zijn vaak evidenter dan de opbrengsten. Echter, bedrijven die actief en veelvuldig dergelijk BPV-plaatsen aanbieden, ervaren al op korte termijn de volgende voordelen:

- een toegenomen instroom van nieuwe, jonge medewerkers;

- verbeterde processen door input van de stage/afstudeeropdrachten;

- medewerkers worden door vragen van de jongeren gedwongen om weer eens na te denken over de manier waarop ze dingen doen en of het niet beter/handiger/efficiënter kan.

\subsection{Recente werkgelegenheidsontwikkelingen}

Figuur 3.5 in de vorige paragraaf heeft laten zien dat de economische crisis de totale werkgelegenheid in de Metalektro heeft doen krimpen vanaf de tweede helft van 2008. In deze paragraaf wordt ingegaan op de werkgelegenheidsontwikkeling per functiecategorie in 2009. In figuur 3.6 wordt het aandeel bedrijven met krimpende werkgelegenheid per functiecategorie weergegeven. De figuur laat zien dat er in de tweede helft van 2009 aanzienlijk minder bedrijven met krimpende werkgelegenheid zijn dan in de eerste helft van het jaar. Zo had in de eerste helft van 2009 nog bijna de helft van de bedrijven te kampen met krimpende werkgelegenheid in de uitvoerende technische functies en ondersteunende niet-technische functies, in de tweede helft was dit nog slechts één op de vijf bedrijven.

Ook bij de andere functiecategorieën nam het percentage bedrijven met krimpende werkgelegenheid fors af gedurende het jaar: het percentage bedrijven met krimpende werkgelegenheid in de ondersteunende technische functies daalde van 38\% naar $16 \%$. In de leidinggevende technische functies had $22 \%$ van de bedrijven een krimpende werkgelegenheid in de eerste helft van het jaar, maar slechts I0\% in de tweede helft van 2009. Voor de technisch opgeleide verkopers had bijna geen enkel bedrijf in de tweede helft van het jaar nog een krimpende werkgelegenheid. Het lijkt er dus op dat de ergste klappen van de crisis in de eerste helft van 2009 zijn gevallen. In de tweede helft van 2009 kwam krimpende werkgelegenheid immers nauwelijks vaker voor dan bijvoorbeeld in de eerste helft van 2007. Voor de gevolgen van krimpende werkgelegenheid voor de bedrijven zie hoofdstuk I, waarin de maatregelen naar aanleiding van de crisis beschreven worden. 


\section{Figuur 3.6}

Aandeel bedrijven met krimpende werkgelegenheid per functiecategorie

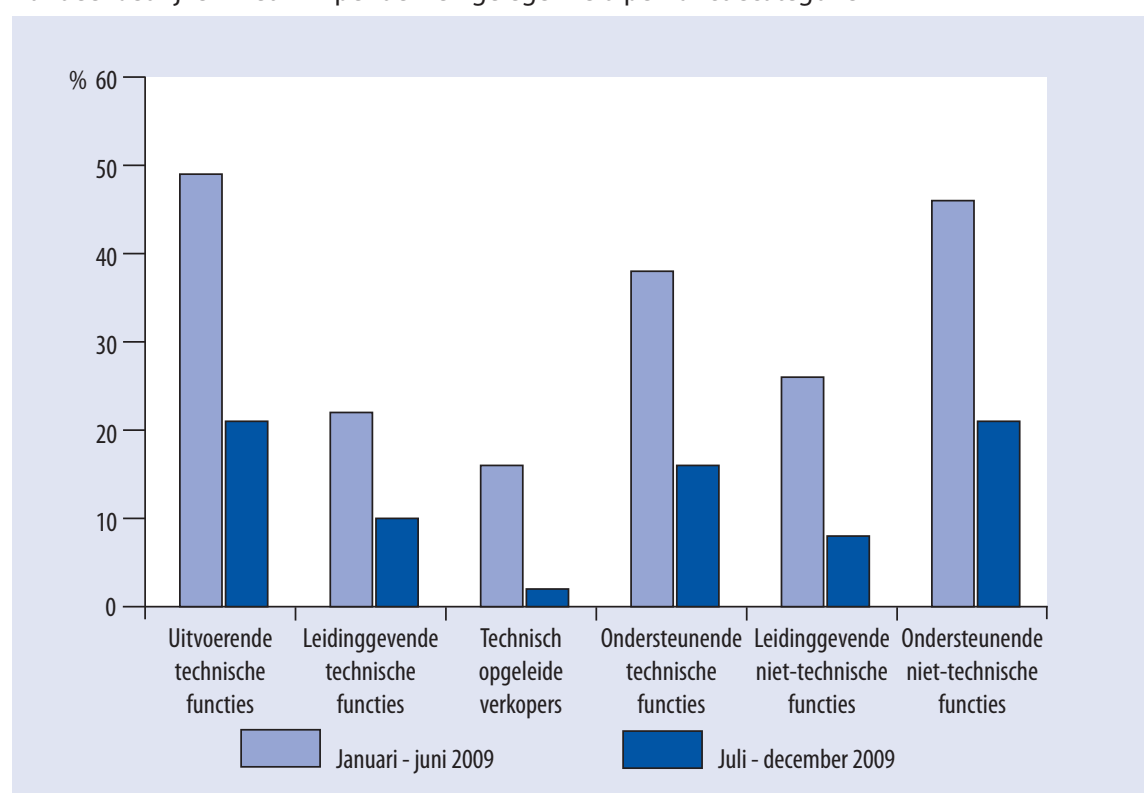

Bron: ROA / Werkgeverspanel Metalektro 2009

In figuur 3.7 wordt voor de uitvoerende technische functies en de leidinggevende technische functies de ontwikkeling van het percentage bedrijven met krimpende werkgelegenheid in deze functies weergegeven. Het gaat om de gemiddelde percentages per jaar, dus het gemiddelde over alle metingen van het jaar. In de jaren 20032004 waren dit drie metingen, sinds 2005 twee metingen.

Bij beide functiecategorieën komt hetzelfde beeld naar voren: een sterk dalende trend tussen 2003 en 2007 gevolgd door een sterke stijging in 2008 en 2009. Zowel de daling als de stijging is hierbij sterker voor de uitvoerende technische functies. Het percentage bedrijven met krimpende werkgelegenheid in deze functies daalde van $40 \%$ in 2003 tot $10 \%$ in 2007 , maar steeg in de afgelopen twee jaar weer tot $35 \%$ in 2009. Het percentage bedrijven met netto personeelsuitstroom in de leidinggevende technische functies daalde van $21 \%$ in 2002 tot $4 \%$ in 2007 , maar steeg daarna weer bijna tot het niveau van 2003: $16 \%$ in 2009 . 


\section{Figuur 3.7}

Ontwikkeling percentage bedrijven met krimpende werkgelegenheid in uitvoerende en leidinggevende technische functies

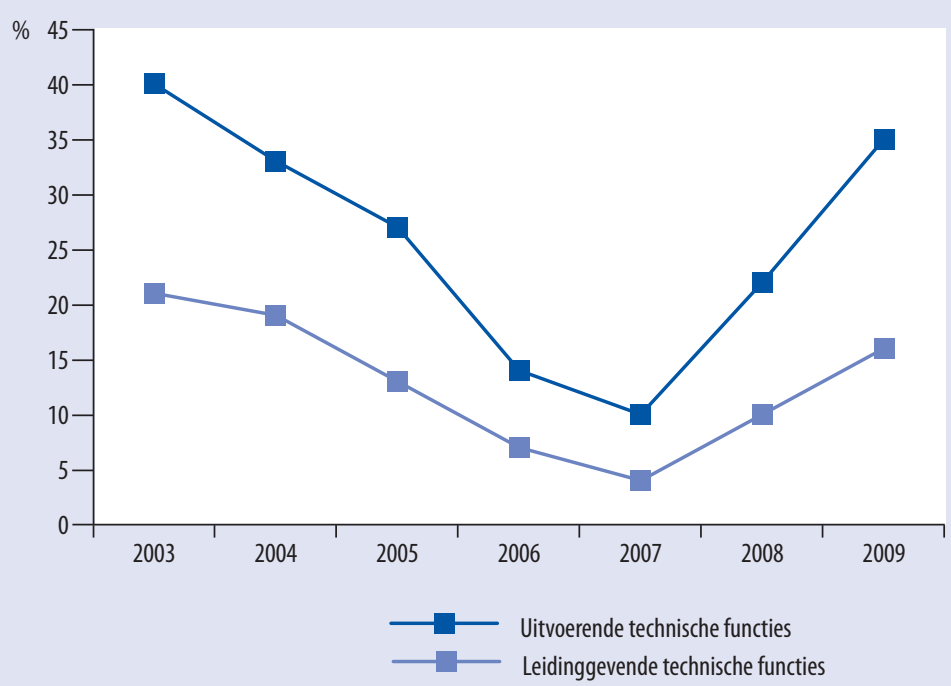

Bron: ROA / Werkgeverspanel Metalektro 2003-2009

\subsection{Flexibele arbeid in de Metalektro}

In deze paragraaf staat de inzet van flexibele arbeidskrachten in de Metalektro centraal. De vorige Arbeidsmarktmonitor Metalektro liet zien dat er eind 2008 sprake was van een sterke afname in het aantal werknemers zonder dienstverband: als gevolg van de financiële crisis ontdeden veel bedrijven zich van hun flexibele schil om hun vaste werknemers in dienst te kunnen houden. Heeft deze trend zich in 2009 voortgezet of worden er door de bedrijven in de Metalektro al weer meer flexibele arbeidskrachten ingezet? In figuur 3.8 wordt het totale aantal flexibele arbeidskrachten bij de bedrijven weergegeven per functiecategorie. 


\section{Figuur 3.8}

Aantal flexibele arbeidskrachten in de Metalektro per functiecategorie

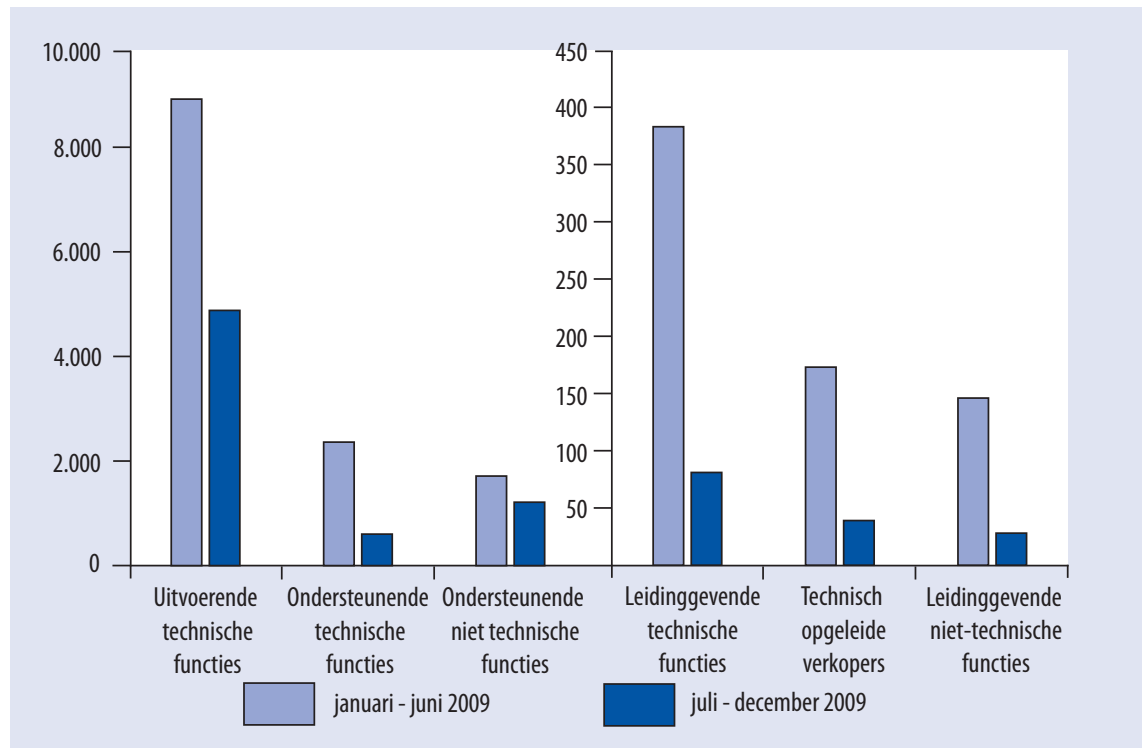

Bron: ROA / Werkgeverspanel Metalektro 2009

In de eerste helft van 2009 waren er bij de bedrijven in de Metalektro in totaal 13.700 flexibele arbeidskrachten werkzaam: een lichte stijging van het aantal flexwerkers ten opzichte van de tweede helft van 2008 (I2.700), maar veel minder dan in de eerste helft van 2008, toen er nog 2I.IOO flexibele arbeidskrachten in de Metalektro werkzaam waren. In de tweede helft van 2009 echter, werkten er nog slechts flexibele 6.840 arbeidskrachten in de Metalektro. De afnemende uitstroom van werknemers die in dienst waren van de metalektrobedrijven staat in schril contrast met de sterke daling van het aantal ingeleende werknemers. In alle functiecategorieën nam het aantal flexibele arbeidskrachten in de loop van 2009 verder af. Veruit de meeste flexibele arbeidskrachten zijn werkzaam in uitvoerende technische functies, maar het aantal flexwerkers in deze functies liep terug van 8.920 naar 4.880 . Het aantal flexibele arbeidkrachten in de ondersteunende technische- en niet-technische functies nam af van respectievelijk 2.360 tot 600 en van I.7IO tot I.2IO. In de leidinggevende functies bleef er in de tweede helft van het jaar slechts een fractie van het aantal flexwerkers in de eerste helft van 2009 over: bij de technische functies 80 van de 390 en bij de niettechnische functies 30 van de I50. Hetzelfde kan gezegd worden over de technisch opgeleide verkopers. In de tweede helft van 2009 waren er nog maar 40 technisch opgeleide verkopers zonder dienstverband bij de bedrijven in de Metalektro terwijl dit er in de eerste helft van 2009 nog 170 waren. 


\section{De zegeningen van de flexibele schil}

Uit o.a. de Quickscan is gebleken dat de flexibele schil van werknemers in twee derde van de metalektrobedrijven een cruciale rol heeft gespeeld in het opvangen van de vraaguitval als gevolg van de crisis. Een aantal geïnterviewde bedrijven heeft dan ook aangegeven dat de crisis het gelijk van het opbouwen van een flexibele schil nu wel heeft bewezen.

0ok een bedrijf waarin men voor de crisis nog van mening was dat de verhouding flexibel - vast personeel wat te veel naar flexibel was doorgeslagen, trok na de crisis de conclusie dat de verhouding precies goed was geweest. De crisis noopte dit bedrijf namelijk tot het loslaten van de complete flexibele schil. Men is zich er wel van bewust dat een flexibele schil de noodzaak tot een onmiddelijke reorganisatie weghaalt, die, als de crisis te lang aanhoudt, wellicht alsnog moet plaatsvinden.

De flexibele schil bestaat bij sommige bedrijven overigens uit meerdere lagen. Zo beschikt een zeker metalektrobedrijf over twee flex-groepen waarbij de hoeveelheid tijd die nodig is om het takenpakket aan te leren bepaalt tot welke van de twee groepen een flex-medewerker behoort. In mindere tijden wordt als eerste afscheid genomen van de mensen uit de groep die taken hebben waarvoor de minste inleertijd nodig is.

\subsection{Vacatures in de Metalektro}

Zijn er ondanks de sterk teruglopende werkgelegenheid in de Metalektro door de economische crisis nog vacatures bij de bedrijven? In deze paragraaf wordt die vraag beantwoord en wordt bovendien ingegaan op de ontwikkeling van de vacatures in de periode 2002-2009. De cijfers zijn gebaseerd op de twee jaarmeting onder de panelleden. Daarnaast is ook in hoofdstuk 2 informatie over de feitelijke en de verwachte ontwikkeling van de vacatures te vinden. Het verschil is dat in hoofdstuk 2 de indicator van vacatureontwikkeling gebaseerd is op een globale inschatting over de verandering van de vacatures weergegeven wordt, terwijl in dit hoofdstuk de daadwerkelijke aantallen vacatures en met gedetailleerdere informatie weergegeven worden.

\section{Onbekend maakt onbemind}

Arbeidsmarktcommunicatie is voor bedrijven mét vacatures, maar zonder klinkende naam van groot belang. Een metalektrobedrijf dat hier fors in investeerde merkte op dat het moeilijke van goede arbeidsmarktcommunicatie is het vinden van de juiste kanalen om met je doelgroep(en) te communiceren. Het bleek een kwestie van 'trial and error', want wat "leest nu een HTS-er?". 


\section{Figuur 3.9}

Ontwikkeling totaal aantal vacatures in de Metalektro, juni 2002 - december 2009

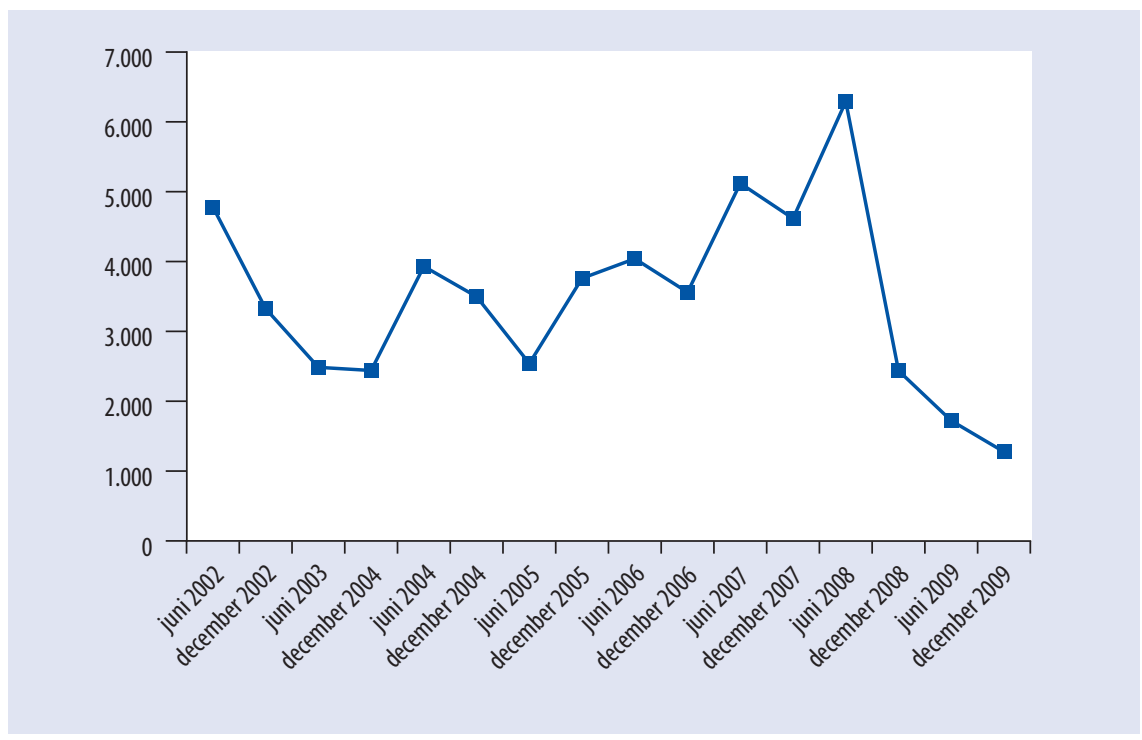

Bron: ROA / Werkgeverspanel Metalektro 2002-2009

Er waren sinds het bestaan van de Arbeidsmarktmonitor nog nooit zo weinig vacatures in de Metalektro als in 2009. In figuur 3.9 wordt de ontwikkeling van het totaal aantal vacatures in de Metalektro tussen 2002 en 2009 weergegeven. In december 2008 duikelde het aantal vacatures al van het maximum antal van 6.290 naar het toenmalig minimum van 2.440. In 2009 zette de daling zich verder door. In juni 2009 hadden de bedrijven in de Metalektro nog I.720 openstaande vacatures, terwijl dat er in december 2009 nog maar I.275 waren. Tussen juni 2002 en december 2003 liep het aantal vacatures terug van 4.780 naar 2.440 , ook toen door een economische recessie. Sindsdien was er echter sprake van een flink stijgende trend waarbij het aantal vacatures, hoewel schommelend per half jaar, toenam tot de eerdergenoemde 6.290 vacatures in juni 2008 .

Het aantal vacatures per functiecategorie is in 2009 ook gedaald ten opzichte van 2008. Zo waren er in december 2008 nog I.300 vacatures voor uitvoerende technische functies. In juni 2009 waren dit er nog maar 830 en in december 2009 nog slechts 690; een fractie van de 3.600 vacatures die er voor uitvoerende technici nog waren in juni 2008. Slechts een kwart van de bedrijven had in juni 2009 vacatures voor uitvoerende technische functies, in december had nog 30\% van de bedrijven een dergelijke vacature. Het antal vacatures voor leidinggevende technische functies (bij $15 \%$ van de bedrijven) daalde van 340 in december 2008 tot 275 in juni 2009 en verder tot 170 in december 2009. Voor technisch opgeleide verkopers bleef het aantal vacatures ten opzichte van december 2008 redelijk stabiel: aanvankelijk een daling van I2O naar 
90 in juni 2009, maar in december 2009 wederom 120 vacatures. Zo'n 9\% van de bedrijven zocht nog technisch opgeleide verkopers in 2009. In juni 2009 waren er 3IO vacatures voor ondersteunende technische functies bij $16 \%$ van de bedrijven, in december 2009 nog 185 bij I4\% van de bedrijven. Een jaar eerder waren dit er nog 480. Ook voor de niet-technische leidinggevende en ondersteunende functies nam het aantal vacatures gedurende 2009 verder af. Respectievelijk van 85 tot 30 vacatures bij ongeveer $5 \%$ van de bedrijven en van I3O tot 85 vacatures bij IO\% van de bedrijven.

In figuur 3.IO wordt wederom de ontwikkeling van het aantal vacatures weergegeven, maar dan onderscheiden naar hoe lang de vacatures blijven openstaan. Omdat dit pas sinds 2005 op deze manier aan de bedrijven wordt gevraagd, worden in deze figuur alleen de jaren 2005 tot en met 2009 weergegeven.

\section{Figuur 3.10}

Ontwikkeling aantal vacatures, onderscheiden naar het aantal maanden dat deze vacatures openstaan

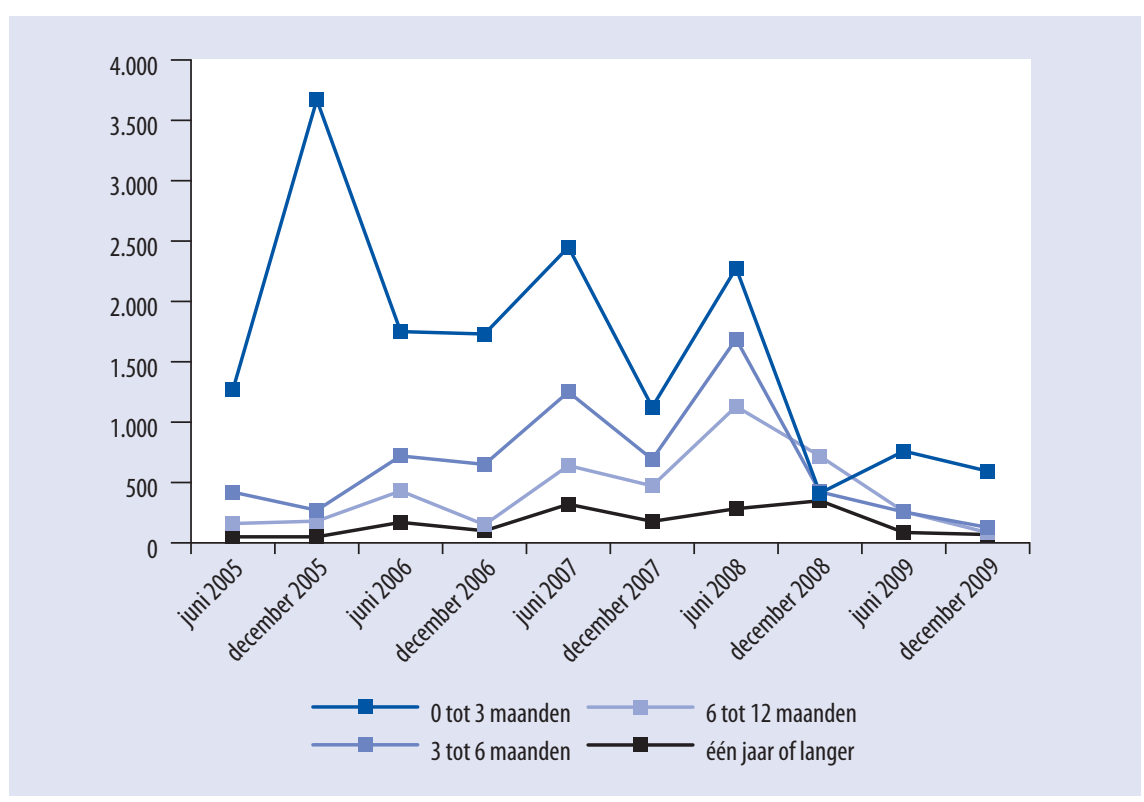

Bron: ROA / Werkgeverspanel Metalektro 2005-2009

In juni 2009 waren er nog 720 vacatures die nul tot drie maanden openstonden. In december 2009 waren er nog 595 vacatures die relatief kort openstonden. Iets minder dan in de eerste helft van 2009, maar wel meer dan in december 2008, toen het aantal kort openstaande vacatures het laagst was van de gehele periode 2005 tot en met 2009. Vooral in december 2005 (3670), juni 2007 (2450) en juni 2008 (2275) waren er relatief veel vacatures die nul tot drie maanden openstonden. Langer openstaande vacatures waren er in juni 2009 niet veel meer. Zo hadden de bedrijven in de Metalektro in 
juni 2009 in totaal nog 255 vacatures die drie tot maanden openstonden; in december 2009 liep dit aantal verder terug tot I30. In de voorgaande jaren was het aantal vacatures dat drie tot zes maanden openstond nog geleidelijk verviervoudigd van 420 in juni 2005 tot 1690 in juni 2008. In december 2008 was dit aantal dankzij de snel teruglopende werkgelegenheid in één klap weer terug op het niveau van juni 2005 . Het aantal vacatures dat zes tot twaalf maanden of zelfs een jaar of langer openstond volgde een soortgelijke ontwikkeling tussen 2005 en 2009. In juni 2009 waren er 260 vacatures die al zes tot twaalf maanden openstonden en 85 vacatures die zelfs al minstens een jaar niet vervuld waren. In december 2009 daalden deze aantallen lang openstaande vacatures verder tot 85 vacatures die zes tot twaalf maanden openstonden en 70 vacatures die al minstens een jaar openstonden. In de jaren daarvoor steeg het aantal vacatures dat zes tot twaalf maanden openstond zeer sterk van I60 in juni 2005 tot I.I3O in juni 2008. Het aantal vacatures dat al minstens een jaar openstond steeg van 50 in 2005 tot 350 in december 2008.

\subsection{Vrijwillig vertrek en werving van technisch personeel}

\section{Vrijwillig vertrek}

Het valt te verwachten dat er in deze economisch slechte tijden veel minder vrijwillig vertrek van personeel is dan toen het nog voorspoedig ging op de arbeidsmarkt in de Metalektro. Toch wordt in deze paragraaf nog kort stil gestaan bij de mate waarin de bedrijven in de Metalektro te maken hebben met vrijwillig vertrek van technisch personeel.

In 2009 heeft maar liefst $78 \%$ van de bedrijven aangegeven dat er erg weinig of geen vrijwillig vertrek van technisch personeel was. In 2007 en 2008 betrof dit nog maar $45 \%$ en $33 \%$ van de bedrijven Nog eens I6\% van de bedrijven heeft in 2009 aangegeven weinig vrijwillig vertrekkende technische werknemers te hebben tegenover $23 \%$ en $32 \%$ in 2007 en $2008.94 \%$ van de bedrijven geeft dus aan in 2009 minder vrijwillig vertrek van personeel te hebben dan in 2008 .

De volgende redenen worden het vaakst genoemd als oorzaak van het vrijwillig vertrek van technische werknemers: $30 \%$ zegt dat technische werknemers uit zichzelf vertrekken omdat zij onvoldoende loopbaanperspectief in hun huidige functie zien. Een kwart van de bedrijven met vertrek van personeel zegt dat technisch personeel vertrekt omdat zij ontevreden zijn met hun salaris. I4\% noemt als reden moeilijkheden om werk en privé met elkaar te kunnen combineren en $12 \%$ van de bedrijven noemt onvoldoende mogelijkheden voor functieroulatie en/of brede inzetbaarheid als reden van vertrek. 
Figuur 3.11

Mate van vrijwillig vertrek van technisch personeel ten opzichte van het voorgaande jaar

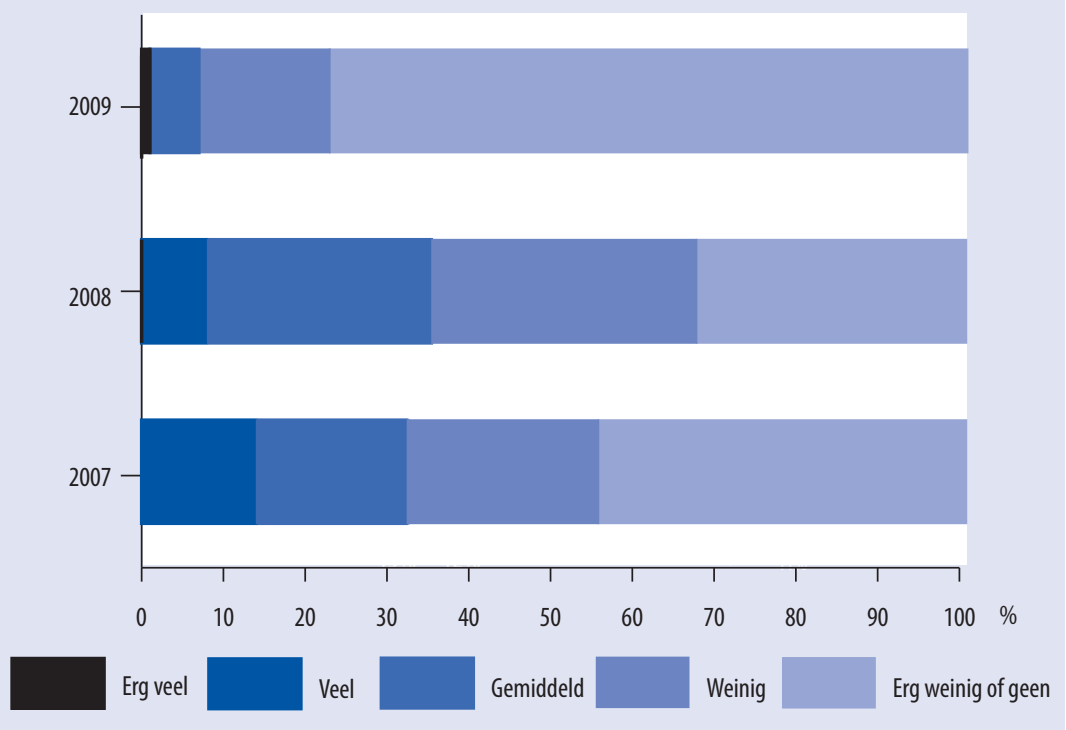

Bron: ROA / Werkgeverspanel Metalektro 2007-2009

Hoe gaan de bedrijven het vrijwillig vertrek van technische werknemers tegen? In 2009 gebeurde dit door te zorgen voor voldoende ontwikkelings- en opleidingsmogelijkheden $(64 \%)$, zorgen voor inhoudelijk interessant werk $(63 \%)$, goede secundaire arbeidsvoorwaarden te bieden (52\%), functieroulatie en/of brede inzetbaarheid te stimuleren $(48 \%)$ en een concurrerend salaris te bieden $(44 \%)$.

\section{Werving van technisch personeel}

Samenhangend met het aantal openstaande vacatures is de vraag in welke mate de bedrijven in de Metalektro met problemen kampen bij de werving van technische medewerkers. Figuur 3.12 laat de ontwikkeling zien van het percentage bedrijven met problemen bij de werving van technisch personeel tussen 2002 en 2009.

In 2009 had $46 \%$ van alle bedrijven geen enkel probleem bij de werving van technisch personeel en $8 \%$ en $\mathrm{I} 4 \%$ van de bedrijven hadden respectievelijk erg weinig en weinig problemen. Slechts $7 \%$ ondervond veel problemen en bijna geen enkel bedrijf (I\%) had erg veel problemen bij de werving van technische werknemers. Dat was in de voorgaande jaren wel anders. Tussen 2004 en 2008 nam het percentage bedrijven met gemiddelde, veel of erg veel problemen bij de werving van technisch personeel sterk toe, terwijl het percentage bedrijven met geen of weinig problemen flink terugliep. Sinds de economische crisis is er van veel wervingsproblemen geen sprake meer. Door 
de veel ruimere arbeidsmarkt zijn er genoeg potentiële werknemers op de markt voor de bedrijven die nog wel technisch personeel werven.

\section{Figuur 3.12}

Ontwikkeling van de mate van wervingsproblemen bij technisch personeel

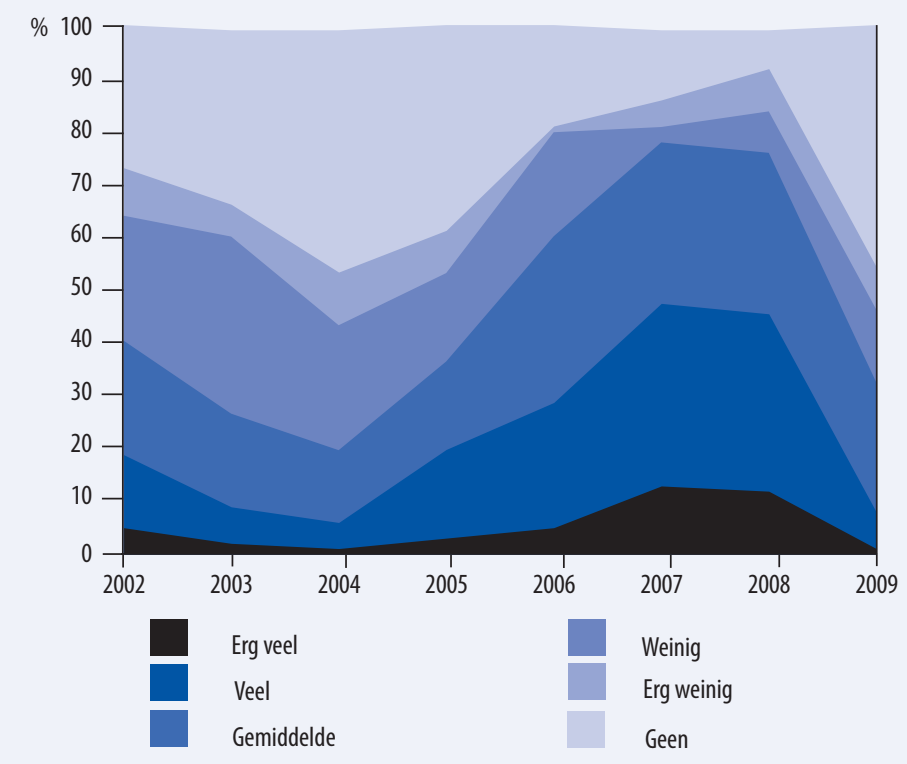

Bron: ROA / Werkgeverspanel Metalektro 2002-2009

Figuur 3.13 laat voor de verschillende soorten technische functies zien welk deel van de bedrijven problemen ondervindt bij het vinden van personeel. Ondanks de veel geringere wervingsproblemen bij de bedrijven, zijn er in 2009 nog steeds bedrijven die problemen ondervonden bij het vinden van technische werknemers. Vooral bij uitvoerende technische functies ondervonden veel bedrijven nog problemen bij de werving: $65 \%$ van de bedrijven. Dit is wel minder dan in voorgaande jaren, toen dit percentage opliep van $74 \%$ in 2006 tot $81 \%$ in 2008 . Bijna vier op de tien bedrijven kampte in 2009 met problemen bij het werven van nieuwe werknemers voor ondersteunende technische functies. In 2008 was dit nog $46 \%$. Met $32 \%$ van de bedrijven hebben in 2009 meer bedrijven dan in 2008 problemen bij het vinden van technische leidinggevenden gehad. Slechts I4\% van de bedrijven had in 2009 problemen met het vinden van technisch opgeleide verkopers; in 2008 was dit percentage nog $23 \%$. 


\section{Figuur 3.13}

Ontwikkeling percentage bedrijven dat problemen ondervindt bij het vinden van technisch personeel, per functiecategorie

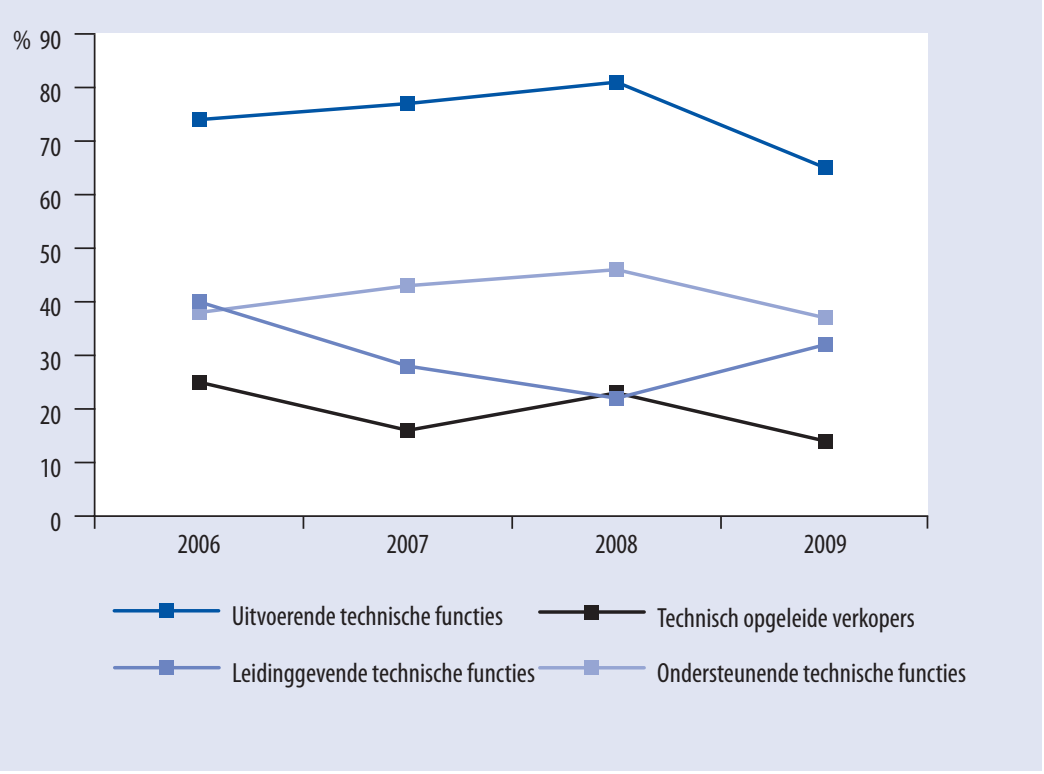

Bron: ROA / Werkgeverspanel Metalektro 2006-2009

Hoe komt het dat bedrijven nog steeds problemen ondervinden bij de werving van technisch personeel? De belangrijkste problemen die bedrijven nog ondervinden zijn sollicitanten die niet de juiste competenties hebben (62\%), onvoldoende werkervaring hebben $(43 \%)$, te hoge salariseisen stellen $(31 \%)$ of dat er simpelweg onvoldoende aanbod van sollicitanten is $(26 \%)$. 


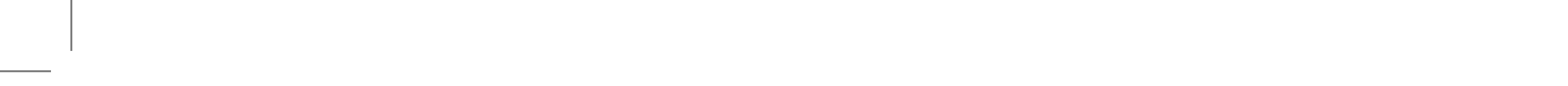




\section{Loopbaanmanagement}

Het ontwikkelen van medewerkers in de Metalektro staat in dit hoofdstuk centraal. Wanneer dit ontwikkelen planmatig gebeurt, spreekt men van loopbaanmanagement. De eerste paragraaf beschrijft de onderdelen van loopbaanmanagement bestaat en gaat uitgebreid in op het eerste onderdeel: het vaststellen van de huidige en de gewenste competenties. In paragraaf 4.2 worden de competenties van de, voor de Metalektro belangrijke, schoolverlaters wit de technische beroepsopleidingen belicht. De ontwikkeling van de competenties van het technische personeel wordt beschreven in de paragrafen 4.3 (ontwikkeling door scholing) en 4.4 (ontwikkeling door interne mobiliteit). Tot slot wordt in paragraaf 4.5 een compleet overzicht gegeven van het gebruik van loopbaaninstrumenten in de Metalektro.

\subsection{Vaststellen huidig en gewenst competentieniveau}

Vanwege het innovatieve karakter van de bedrijfstak (zie hoofdstuk I en 5), is het noodzakelijk dat de bedrijven in de Metalektro de loopbanen van hun werknemers actief managen. Ook de dynamiek in de afzetmarkten waarop veel metalektrobedrijven actief zijn en de gevolgen van de demografische ontwikkelingen (vergrijzing en ontgroening) dragen bij aan het belang van goed loopbaanmanagement. Al deze facetten leiden er onder andere toe dat het scala aan competenties dat van werknemers in de Metalektro gevraagd wordt gedurende hun loopbaan verandert, zowel qua inhoud, niveau als scope. Om de werknemers gedurende hun hele loopbaan optimaal inzetbaar te houden voor het bedrijf en de bedrijfstak, dienen bedrijven voldoende aandacht te hebben voor loopbanen van hun personeel.

Loopbaanmanagement bestaat hoofdzakelijk uit twee stappen. In de eerste stap wordt het huidige scala aan competenties van de werknemer vastgesteld, alsmede welke competenties in de toekomst gewenst zijn. Bij het vaststellen van dit 'wensenlijstje' dient met de behoeften en de mogelijkheden van zowel het bedrijf als de werknemer rekening te worden gehouden. De tweede stap bevat het traject dat de werknemer en het bedrijf doorlopen om de competenties van de werknemer dusdanig te ontwikkelen dat deze overeenkomen met het gewenste scala aan competenties. Dit traject kan bijvoorbeeld bestaan uit formele scholing (zie paragraaf 4.3) of informeel leren on the job door interne mobiliteit (zie paragraaf 4.4). 
In deze paragraaf zal de eerste stap van het loopbaanmanagement verder worden uitgediept. Vier instrumenten van het loopbaanmanagementinstrumentarium zijn bij uitstek geschikt om te bepalen welke competenties een werknemer op een bepaald moment bezit en op welk niveau deze competenties zich bevinden. Dit zijn:

- functioneringsgesprekken;

- beoordelingsgesprekken;

- competentie- of vaardighedenmatrix;

- vastleggen van EVC's (Eerder Verworven Competenties).

\section{Figuur 4.1}

HRM-instrumenten die worden gebruikt voor het vaststellen (van het niveau) van de huidige en gewenste competenties (\% bedrijven)

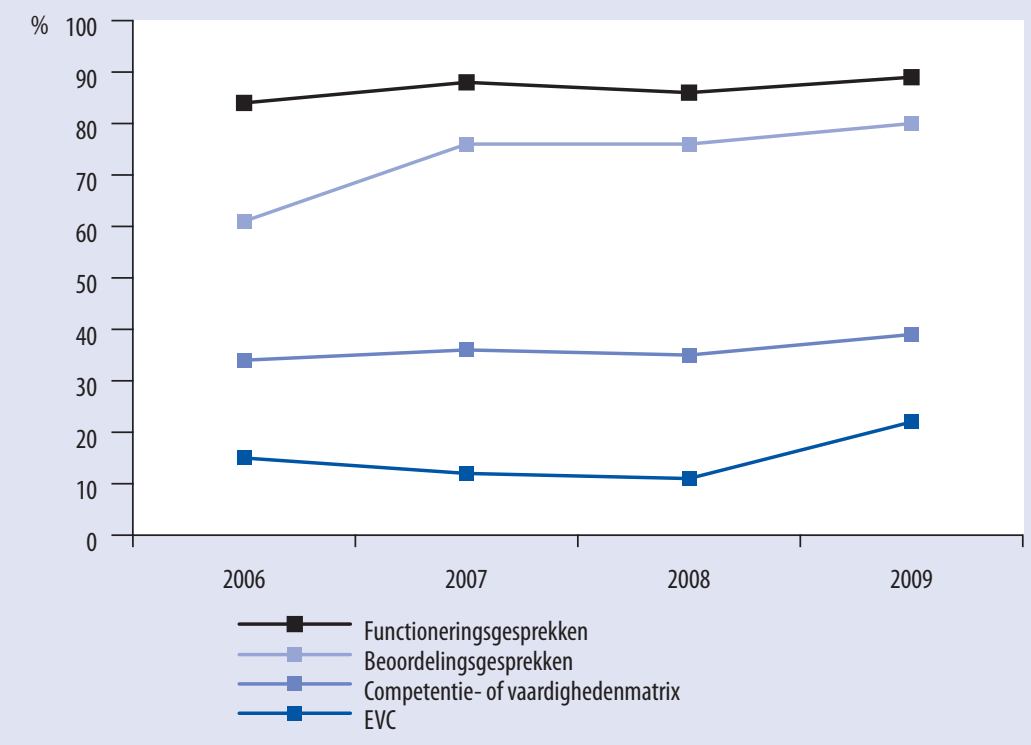

Bron: ROA / Werkgeverspanel Metalektro 2006-2009

Figuur 4.I laat zien in welke mate deze instrumenten door metalektrobedrijven gebruikt worden. Functioneringsgesprekken zijn al enkele jaren gemeengoed in de Metalektro: in 2009 voert negen van de tien bedrijven dergelijke gesprekken. Daarnaast zijn in de afgelopen jaren beoordelingsgesprekken steeds meer in zwang geraakt: in 2009 houden acht van de tien bedrijven beoordelingsgesprekken met hun personeel. Een competentie- of vaardighedenmatrix wordt de laatste jaren structureel door een derde van de bedrijven opgesteld. EVC lijkt in 2009 aan een behoorlijke opmars bezig: het gebruikerspercentage verdubbelde tussen 2008 en 2009 van II\% naar $22 \%$ van alle metalektrobedrijven. 
Functionerings- en beoordelingsgesprekken en een EVC traject bieden, mits goed uitgevoerd, ook volop mogelijkheden voor zowel de werknemers als de werkgever om vast te stellen welke competenties wenselijk zijn en wat het niveau daarvan moet zijn. Een belangrijke factor in het bepalen van de gewenste competenties vormen de verwachtingen van bedrijven ten aanzien van de ontwikkeling van de functies waarin hun werknemers werkzaam zijn. Zullen deze het komend jaar veranderen en zo ja, op welke manier?

\section{Figuur 4.2}

Wijzigingen in de technische functies in de het komende jaar (\% bedrijven)

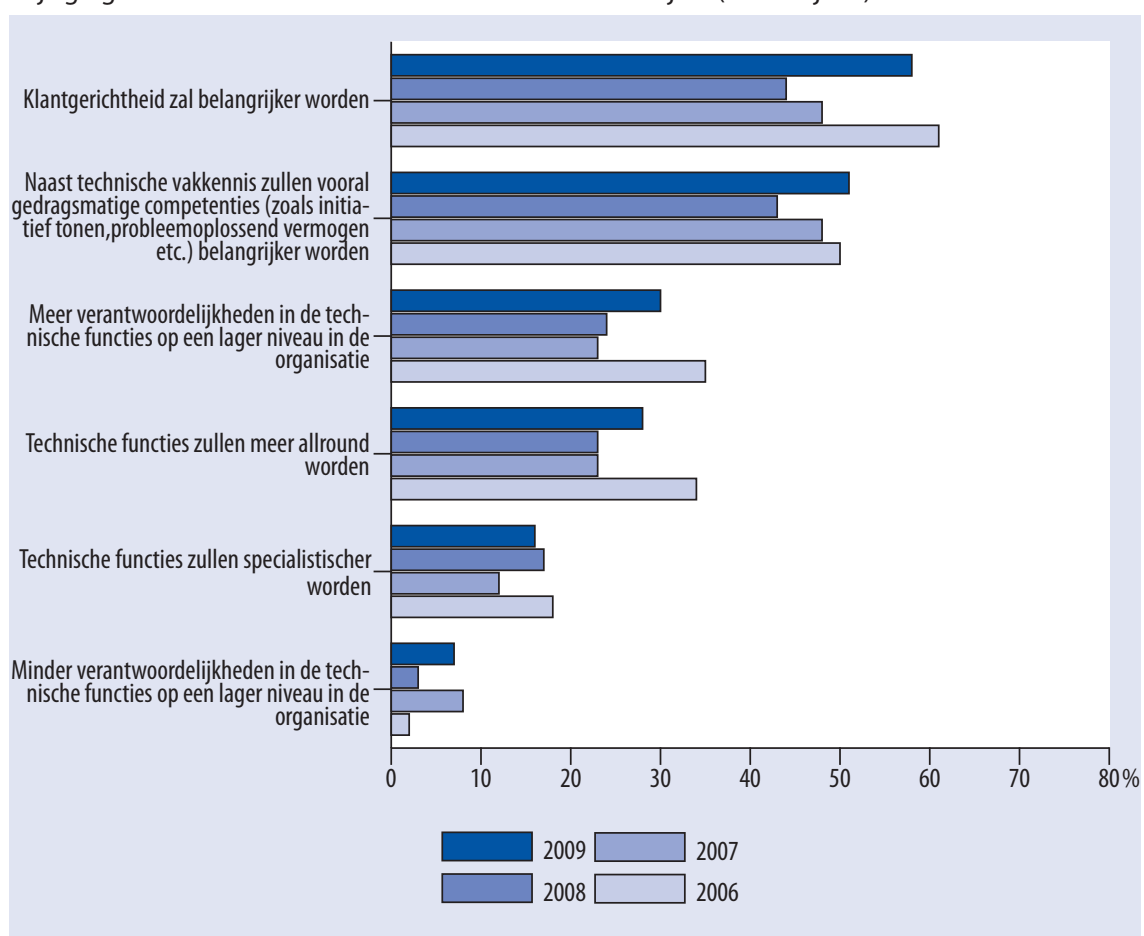

Bron: ROA / Werkgeverspanel Metalektro 2006-2009

In figuur 4.2 is te zien dat bedrijven het vaakst verwachten dat klantgerichtheid in de nabije toekomst voor technische functies van groot belang is. Deze verwachting hebben de bedrijven al enkele jaren, maar worden in 2009 door nog meer bedrijven genoemd dan in voorgaande jaren. De helft van de bedrijven denkt ook dat gedragsmatige competenties belangrijker zullen worden. Bovendien verwacht ruim een kwart van de metalektrobedrijven dat technische functies meer verantwoordelijkheden zullen bevatten en meer allround zullen worden.

Het vaststellen van de huidige en de gewenste competenties is geen eenmalig, maar juist een continu proces dat regelmatig herhaald dient te worden. Door verande- 
ringen in zowel de situatie van het bedrijf als die van de medewerker kunnen zowel de huidige als de gewenste competenties wijzigen. Het lijkt er op dat niet alle bedrijven zich dat voldoende realiseren: ruim $40 \%$ van de bedrijven was het oneens met de Quickscanstelling "Ons bedrijf zou vaker moeten vaststellen wat de werknemers kunnen en willen in hun werk".

\section{Organische carrièrepaden}

Loopbaanmanagement hoeft zeker niet te betekenen dat de carrièrepaden van werknemers bij binnenkomst al volledig vastliggen. Eén van de geïnterviewde bedrijven heeft vele functies, maar deze zijn niet strak gedefinieerd. Dit biedt ruimte aan mensen om nieuwe activiteiten op te pakken en zorgt ervoor dat de carrièrepaden van werknemers eerder organisch dan mechanisch verlopen.

\subsection{Competentieniveau van de schoolverlaters}

In deze paragraaf maken we een uitstapje naar de startende werknemers in de Metalektro. We staan stil bij de aansluiting tussen de gevolgde beroepsopleiding en het werken in de Metalektro en de competenties die volgens starters voor hun huidige functie vereist zijn. De gegevens van deze startende werknemers in de Metalektro zijn verkregen uit de BVE-Monitor en de $H B O$-Monitor van het ROA. In deze monitoren worden afgestudeerden anderhalf jaar na het afronden van hun beroepsopleiding bevraagd. Daarbij richten we ons hier op de afgestudeerden van de studies Elektrotechniek en Werktuigbouwkunde op MBO- en HBO-niveau. Vervolgens zijn de afgestudeerden die werkzaam zijn in de Metalektro uit deze groep geselecteerd. We gebruiken hierbij de meest recente data. Dit zijn de enquêtecijfers uit de jaren 2007 en 2008 , die betrekking hebben op de afgestudeerden die in de schooljaren $2005 / 2006$ en 2006/2007 hun diploma behaalden. Daarbij gaat het in totaal om 2.615 MBO-afgestudeerden en I.2I4 HBO-afgestudeerden.

\section{Aansluiting opleiding-werk}

Van de MBO-afgestudeerden Elektrotechniek en Werktuigbouwkunde die werkzaam zijn in de Metalektro, werkt $76 \%$ in een functie waarvoor minimaal een opleiding op MBO-niveau wordt gevraagd (zie figuur 4.3). 34\% van de MBO-afgestudeerden in de Metalektro werkt in een functie waarvoor specifiek de eigen vakrichting (Elektrotechniek of Werktuigbouwkunde) is vereist, terwijl $49 \%$ werkzaam is in een functie waarvoor de werkgever de eigen óf een verwante opleidingsrichting vraagt. Het merendeel van de MBO'ers vindt de aansluiting tussen de gevolgde opleiding en hun huidige baan in de Metalektro in orde: $57 \%$ van hen vindt de aansluiting voldoende en nog eens $27 \%$ vindt de aansluiting goed. $16 \%$ van deze MBO'ers is dus niet tevreden over de aansluiting tussen de gevolgde opleiding en hun werk in de 
Metalektro. Een derde van de MBO-afgestudeerden voelt zich onderbenut, dat wil zeggen dat in de huidige functie niet al hun kennis en vaardigheden worden benut. Daarentegen loopt $9 \%$ van de MBO'ers op de figuurlijke tenen: hun kennis en vaardigheden schieten tekort voor het uitoefenen van hun functie.

\section{Figuur 4.3}

Aansluiting tussen gevolgde opleiding en huidige functie van MBO- en HBO-afgestudeerden Elektrotechniek of Werktuigbouwkunde werkzaam in de Metalektro

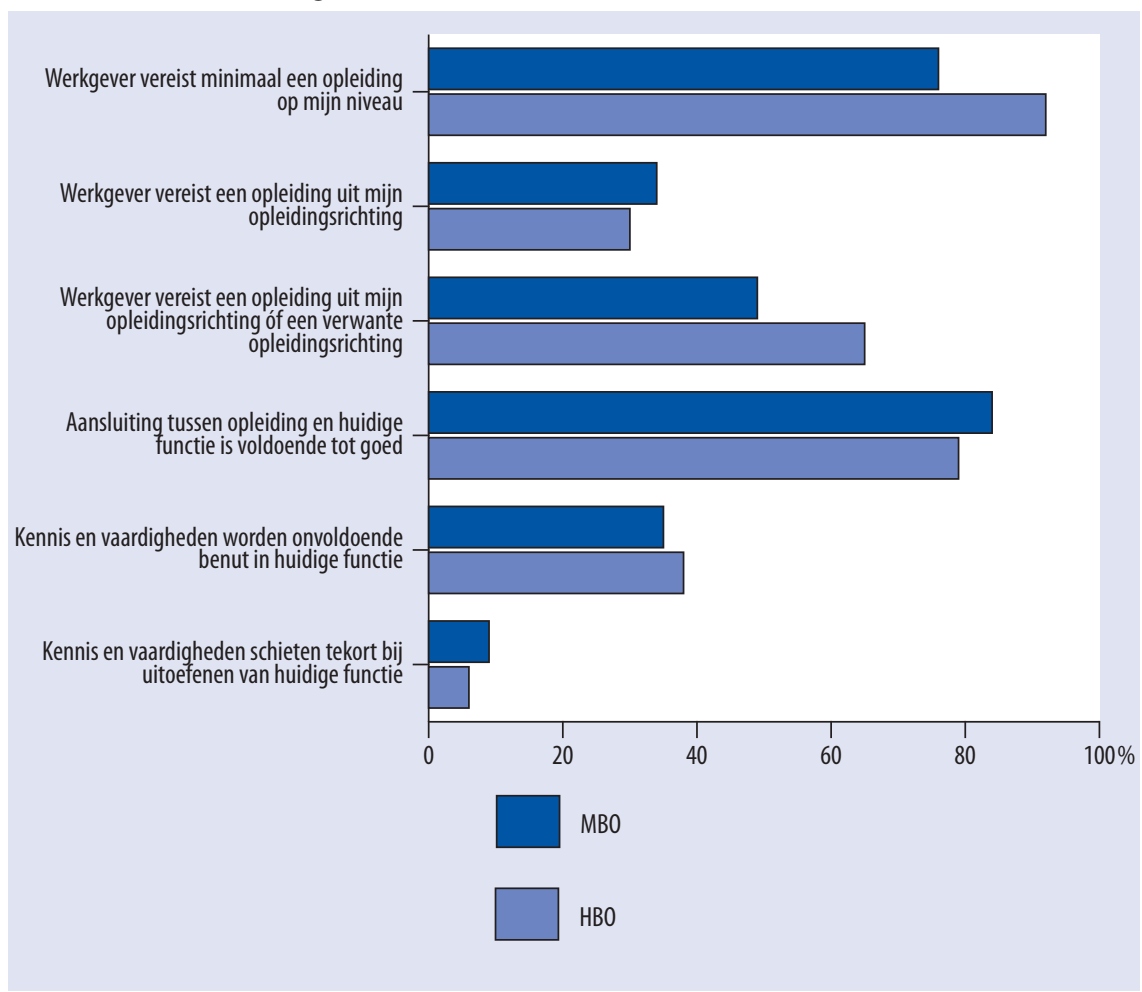

Bron: BVE-monitor en HBO-monitor 2007 en 2008, SIS / ROA

De HBO-afgestudeerden die in de Metalektro werkzaam zijn, werken vaker in een passende baan dan de MBO'ers. Maar liefst 92\% van de HBO-afgestudeerden in de Metalektro werkt in een functie waarvoor minimaal HBO-niveau vereist is. Verder werkt $30 \%$ van deze HBO'ers in een functie waarvoor de eigen opleidingsrichting vereist is en nog eens $65 \%$ werkt in een baan waarvoor de eigen of een verwante opleidingsrichting is vereist. De HBO-afgestudeerden zijn echter wel iets minder vaak tevreden over de aansluiting tussen de gevolgde $\mathrm{HBO}$-opleiding en hun huidige functie dan de MBO'ers: $52 \%$ vindt de aansluiting voldoende en $27 \%$ vindt deze goed. $21 \%$ van deze HBO'ers is dus minder tevreden over de aansluiting tussen hun opleiding en huidige functie in de Metalektro. Daarnaast voelt $38 \%$ van de $\mathrm{HBO}$-afgestudeerden 
zich onderbenut in hun werk, terwijl slechts $6 \%$ van de HBO'ers het idee heeft dat ze qua niveau worden overvraagd in hun huidige functie.

De afgestudeerden zijn ook bevraagd over enkele kenmerken van hun baan in de Metalektro anderhalf jaar na afstuderen: hebben zij een vaste aanstelling en hoeveel uren per week werken zij? Biedt de functie voldoende perspectieven en hoe tevreden zijn ze met hun baan?

Voor veel MBO-afgestudeerden is het contact met de huidige werkgever al tijdens de studie gelegd: $16 \%$ van hen liep tijdens de opleiding stage bij hun huidige werkgever in de Metalektro; maar liefst $40 \%$ had tijdens de opleiding al betaald werk bij hetzelfde bedrijf in de Metalektro, en 22\% liep én stage én werkte reeds bij het Metalektrobedrijf waar men na afstuderen is gaan werken. Daarnaast is de MBO-afgestudeerden ook gevraagd of zij problemen hadden bij het vinden van een beroepsvormingsplaats (stageplaats of leerbaan). Slechts $3 \%$ van hen heeft op dit punt problemen ondervonden. Overigens zochten deze afgestudeerden naar dergelijke plekken in een periode waarin de economie er veel beter voor stond dan het afgelopen jaar.

Een substantieel deel van zowel de MBO- als de HBO-afgestudeerden ziet de carrièremogelijkheden van hun huidige baan in de Metalektro zonnig in: 64\% van de MBO-afgestudeerden en $60 \%$ van de HBO'ers ziet voldoende carrièremogelijkheden in de huidige functie. De afgestudeerden van het $\mathrm{MBO}$ en van het $\mathrm{HBO}$ zijn even vaak tevreden met hun functie in de Metalektro: $68 \%$ van hen is anderhalf jaar na het afronden van hun opleiding in de werktuigbouwkunde of de elektrotechniek tevreden met hun functie in de Metalektro.

\section{Competenties}

In de BVE-Monitor worden afgestudeerden op een andere manier en niet over precies dezelfde competenties bevraagd als in de $\mathrm{HBO}$-Monitor. Daarom worden de competenties van de $\mathrm{MBO}$ - en de $\mathrm{HBO}$-afgestudeerden Elektrotechniek en Werktuigbouwkunde die werkzaam in de Metalektro apart besproken, te beginnen met de MBO'ers. In figuur 4.4 wordt telkens het percentage afgestudeerden weergegeven dat de desbetreffende competentie belangrijk of zeer belangrijk vindt om goed te kunnen functioneren in hun huidige functie.

Uit figuur 4.4 blijkt dat de competenties zelfstandigheid (95\%), nauwkeurigheid/ zorgvuldigheid (91\%), het toepassen van kennis en technieken in de praktijk (90\%) en initiatief/creativiteit (89\%) door vrijwel alle MBO-afgestudeerden als belangrijk of zeer belangrijk voor hun functie worden beschouwd. De meesten van hen vinden deze competenties zelfs zeer belangrijk om goed te kunnen functioneren. Andere competenties die vaak als (zeer) belangrijk voor het werk worden aangeduid zijn: het oplossen van problemen $(86 \%)$, vakkennis $(85 \%)$, werken in teamverband/samenwerken $(83 \%)$, aanpassingsvermogen $(82 \%)$ en het overdragen van kennis $(76 \%)$. Meer 
dan de helft van de schoolverlaters van het $\mathrm{MBO}$ vindt ook de competenties inzicht in milieu- en veiligheidsvoorschriften $(60 \%)$, contactuele vaardigheden $(57 \%)$ en plannen, coördineren en organiseren van activiteiten $(52 \%)$ belangrijk in hun functie in de Metalektro. Van de POFI+ competenties worden dus vooral probleemoplossend vermogen, omgaan met veranderingen en flexibiliteit (aanpassingsvermogen) en initiatief ook door de $\mathrm{MBO}$-afgestudeerden als (zeer) belangrijk erkend.

\section{Figuur 4.4}

Percentage MBO-afgestudeerden werkzaam in de Metalektro dat de volgende competenties (zeer) belangrijk vindt voor hun huidige functie (antwoordopties 4 en 5 op een 5-puntsschaal).

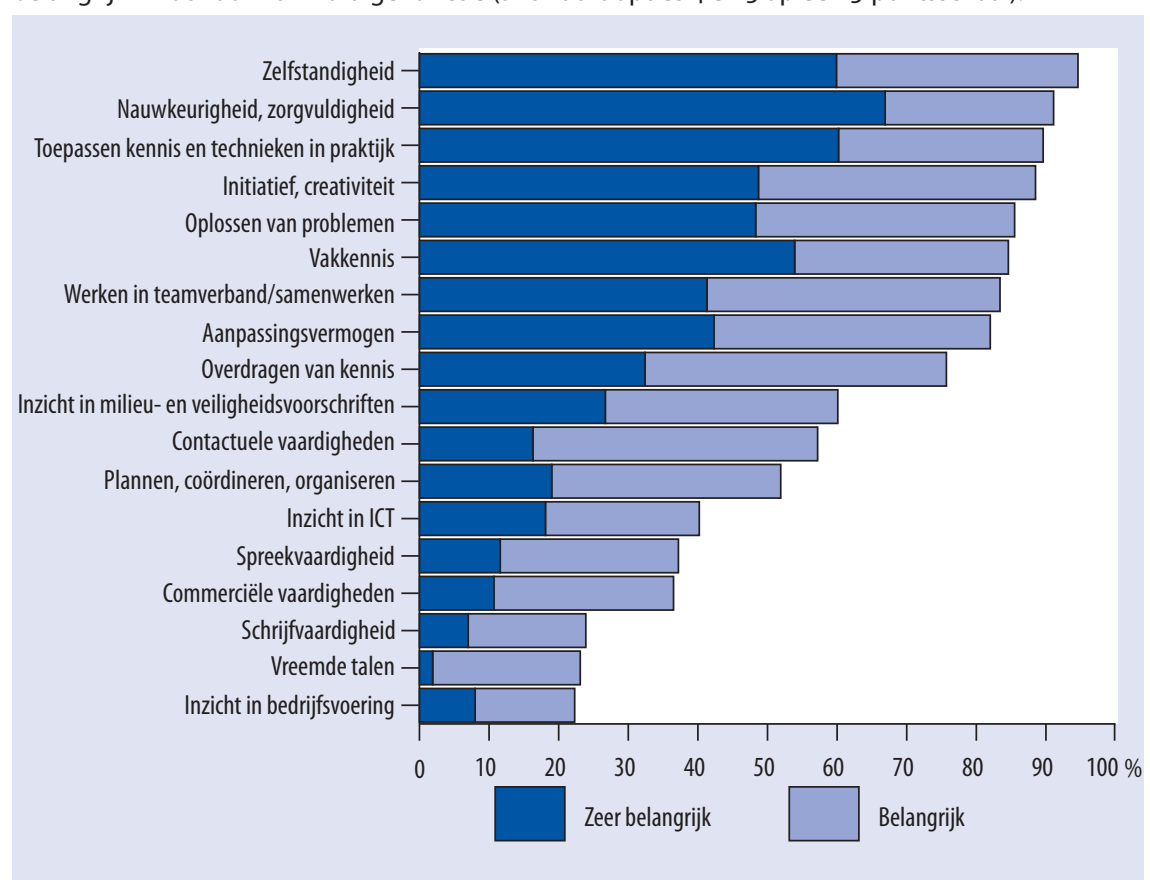

Bron: BVE-Monitor 2007 en 2008, SIS / ROA

In de HBO-monitor wordt zowel naar het vereiste niveau van verschillende competenties in de huidige baan als naar het eigen niveau van deze competenties gevraagd. De competenties wijken daarbij enigszins af van de competenties die aan de MBO'ers worden voorgelegd. In figuur 4.5 worden voor elke competentie twee balken weergegeven. De bovenste balk heeft betrekking op het percentage $\mathrm{HBO}$-afgestudeerden dat vindt dat het vereiste niveau van deze competentie goed of uitstekend moet zijn om hun functie goed uit te kunnen oefenen. De onderste balk geeft het percentage $\mathrm{HBO}$-afgestudeerden weer dat het eigen niveau van deze competentie als goed of uitstekend inschat. 
Het vermogen om zelfstandig werkzaamheden uit te voeren wordt het vaakst genoemd als een competentie waarvoor een goed of uitstekend niveau vereist is in functies waarin de recent afgestudeerde HBO'ers werkzaam zijn: 84\% van de $\mathrm{HBO}$-afgestudeerden geeft dit aan. Ook het vermogen om logisch te redeneren (77\%), het vermogen om problemen en kansen te signaleren $(74 \%)$ en het vermogen om aan een ander duidelijk te maken wat men bedoelt $(73 \%)$ worden erg vaak belangrijk gevonden voor een functie in de Metalektro. Ruim tweederde van de afgestudeerden vindt dat ze ook een goed of uitstekend competentieniveau moeten hebben op de volgende terreinen: het vermogen om productief met anderen samen te werken, bereidheid om op te komen voor het eigen standpunt, bereidheid om ideeën van zichzelf en anderen ter discussie te stellen, bereidheid om begrip te tonen voor andere standpunten, het vermogen om verbanden te leggen tussen verschillende zaken, het vermogen om nieuwe dingen te leren, het vermogen om informatie te vergaren, het vermogen om nieuwe ideeën en oplossingen te bedenken en het vermogen om onder druk goed te functioneren. Opvallend genoeg vindt slechts $57 \%$ dat het vereiste niveau van kennis van het eigen vakgebied goed of uitstekend moet zijn om hun functie goed uit te kunnen oefenen. Ook is interessant om te zien dat $40 \%$ aangeeft dat ze in hun functie een goede of uitstekende kennis moeten hebben van andere vakgebieden.

Een vergelijking tussen het vereiste competentieniveau en het competentieniveau van de HBO-afgestudeerden zelf leert dat het gemiddelde eigen niveau het gemiddelde vereiste niveau niet veel ontloopt. Onderbenutting van competenties vinden we voor het vermogen om nieuwe dingen te leren $(+18 \%)$, bereidheid om de nek uit te steken $(+\mathrm{II} \%)$, het vermogen om productief met anderen samen te werken $(+\mathrm{IO} \%)$, het vermogen om ICT te gebruiken $(+8 \%)$ en de bereidheid om begrip te tonen voor andere standpunten $(+7 \%)$. Dit wijst er op dat deze competenties door de metalektrobedrijven nog beter zouden kunnen worden benut. Daarentegen ervaren de HBOafgestudeerden die recentelijk door de metalektrobedrijven zijn aangetrokken het vaakst dat ze een competentietekort hebben met betrekking tot het vermogen om in buitenlandse talen te communiceren (-I5\%), het vermogen om aan anderen duidelijk te maken wat ze bedoelen $(-8 \%)$, kennis van het eigen vakgebied $(-6 \%)$, kennis van andere vakgebieden $(-5 \%)$ en het vermogen om conform budget, planning of richtlijnen te werken. 


\section{Figuur 4.5}

Percentage HBO-afgestudeerden werkzaam in de Metalektro dat voor het vereist niveau in de baan en voor het eigen niveau van de volgende competenties aangeeft dat dit niveau goed of uitstekend is (antwoordopties 4 en 5 op een 5 -puntsschaal).

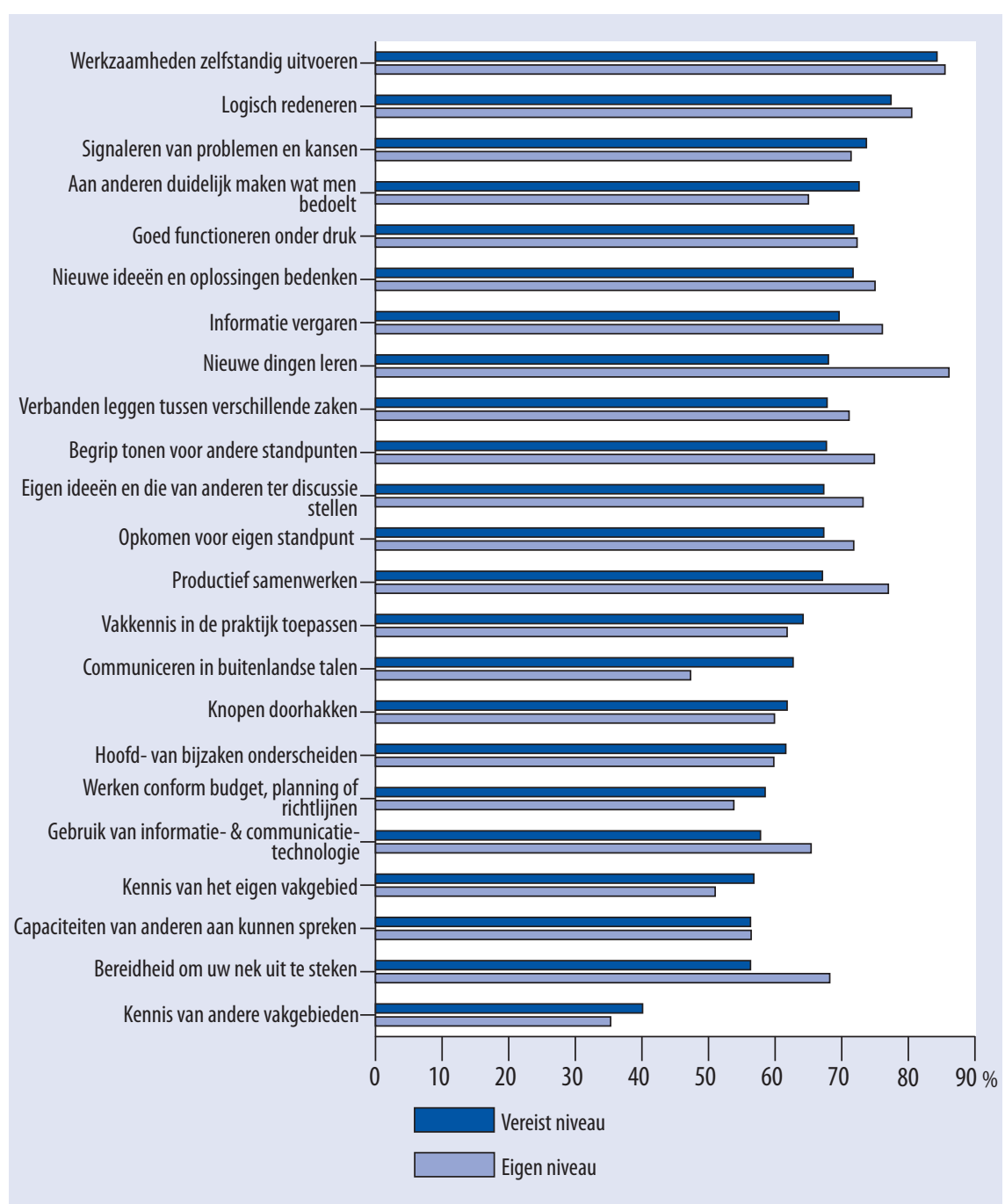

Bron: HBO-Monitor 2007 en 2008, SIS / ROA 


\subsection{Ontwikkeling competenties door scholing}

Veel bedrijven in de Metalektro zien scholing als één van de belangrijkste manieren om de kennis en vaardigheden van hun personeel te verdiepen en te verbreden. Het afgelopen jaar was bovendien een uitgelezen moment om het personeel op te leiden. Door de sterk teruggelopen werkzaamheden was er immers in veel bedrijven tijd over om werknemers te scholen. Dit roept de vraag op of de metalektrobedrijven in 2009 inderdaad meer opleidingsactiviteiten hebben ondernomen. We staan in deze paragraaf eerst stil bij de ontwikkeling van de gemiddelde trainingsdeelname per bedrijf en de ontwikkeling van de kosten van de opleidingsactiviteiten. Daarna gaan we achtereenvolgens in op de inhoud van de trainingen en cursussen die gevolgd zijn, de potentiële belemmeringen die bedrijven bij hun opleidingsactiviteiten ervaren en ten slotte de manieren waarop het volgen van trainingen en cursussen door de bedrijven wordt gestimuleerd.

\footnotetext{
Opleiden in crisistijd: maatwerk en geen cent te veel

Bedrijven hebben in het afgelopen jaar onderkend hoe belangrijk scholing is, ondanks of dankzij de crisis: twee derde van de bedrijven was het in het voorjaar van 2009 (helemaal) eens met de stelling "Het is belangrijk om juist nu de tijd te gebruiken om je vaste personeel te scholen." Door de crisis werd er wel kritischer gekeken naar wat scholing mocht kosten. Sommige bedrijven hebben een vast opleidingsbudget dat niet beïnvloed wordt door een crisis, terwijl het opleidingsbudget bij andere bedrijven een sluitpost vormt op de begroting.

Het (grotere) kostenbewustzijn is 0.a. een verklaring voor het feit dat bedrijven vaker hebben gekozen voor interne trainingen gegeven door eigen medewerkers. Interne trainingen zijn immers goedkoper en kunnen beter op maat worden gesneden dan opleidingen die extern worden ingekocht (bijvoorbeeld bij een ROC). Dit leidde soms tot onbegrip in de directe omgeving van de bedrijven. Aan het einde van de trainingen huurden sommige bedrijven externe examinatoren in zodat de getrainden hun inspanningen beloond zagen met een officieel getuigschrift. Eén van de bedrijven ontdekte door het opzetten van de interne trainingen dat opleidingsinstituten soms gratis trainingsmateriaal verstrekken waar het dankbaar gebruik van heeft gemaakt.
}

\section{Trainings- en cursusdeelname en bijbehorende kosten}

In figuur 4.6 wordt de ontwikkeling weergegeven van het percentage technische werknemers dat in de jaren 2003 tot en met 2009 trainingen of cursussen heeft gevolgd. Er wordt daarbij een onderscheid gemaakt tussen interne cursussen, die binnen het bedrijf gegeven worden, en externe cursussen. In 2009 is de interne opleidingsdeelname fors gestegen. In 2008 volgde gemiddeld nog $23 \%$ van het technische personeel een interne training of cursus, in 2009 is dit opgelopen tot $33 \%$. Dit is een procentuele toename van $45 \%$. Nog nooit gedurende het bestaan van de Arbeidsmarktmonitor lag de interne opleidingsdeelname zo hoog. Dit geeft duidelijk aan dat veel bedrijven de terugval in hun afzet hebben gebruikt om hun personeel via interne cursussen bij te scholen. Als we verder teruggaan in de tijd, zien we dat de gemiddelde interne cursus- 
deelname tussen 2003 en 2005 redelijk stabiel rond de $17 \%$ lag, waarna deze in 2006 sterk terugliep tot $\mathbf{I} 2 \%$. In 2007 en 2008 volgde weer groei naar $18 \%$ en $23 \%$, waarna de deelname aan interne cursussen of trainingen in 2009 zoals gezegd toenam tot $33 \%$ van het technische personeel dat bij de metalektrobedrijven werkzaam is.

\section{Figuur 4.6}

Ontwikkeling gemiddelde trainings- en cursusdeelname in procenten van het aantal technische werknemers

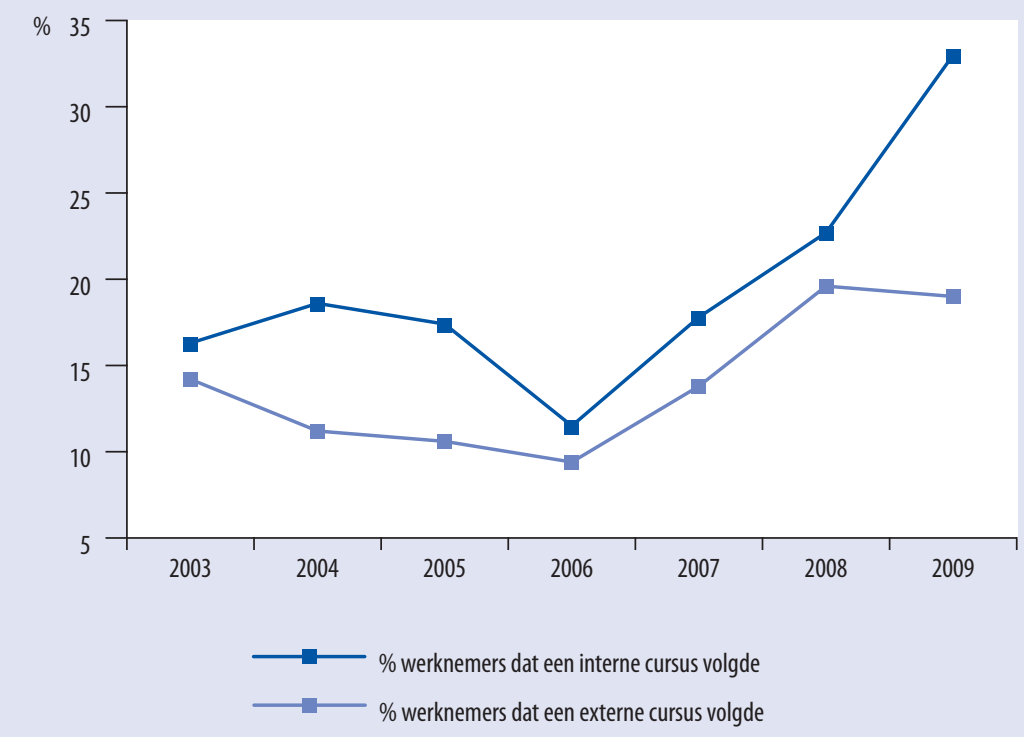

Bron: ROA / Werkgeverspanel Metalektro, 2003-2009

Terwijl de gemiddelde deelname aan interne cursussen in 2009 dus fors is gestegen, geldt dit niet voor de gemiddelde externe cursusdeelname: in 2009 volgde gemiddeld I9\% van de technische werknemers een externe cursus, nagenoeg evenveel als in 2008 . Mogelijk heeft dit te maken met het gegeven dat de economische crisis wel tijd schept voor personeel om cursussen te volgen, maar daarentegen de middelen om deze te bekostigen vermindert. Interne cursussen zullen over het algemeen veel goedkoper zijn dan externe cursussen. In figuur 4.6 is verder te zien dat het percentage technische werknemers dat een externe cursus volgde van 2003 tot 2006 behoorlijk is gedaald van I4 tot $9 \%$. Vanaf 2006 steeg dit percentage echter weer sterk: in 2008 volgde een kleine $20 \%$ van de technische werknemers een externe cursus.

Zoals eerder werd opgemerkt heeft de crisis wel voor de nodige tijd om werknemers op te leiden gezorgd, maar niet voor de bijbehorende financiën. Hoe zijn de metalektrobedrijven omgesprongen met deze spagaat als het gaat om de 'out-of-pocket' 
opleidingskosten? In figuur 4.7 is te zien dat in 2009 de gemiddelde totale opleidingskosten per bedrijf $€ 5$ I.IOo bedroegen. Dit houdt een lichte stijging ten opzichte van 2008 in, toen er gemiddeld $€ 50.500$ aan opleidingen werd besteed. Als we de ontwikkeling over de tijd bekijken dan zien we dat de metalektrobedrijven in 2003 veruit het meeste uitgaven aan opleidingskosten: gemiddeld ongeveer $€ 65.000$ per bedrijf. In 2004 zijn de gemiddelde opleidingskosten fors gedaald, tot $€ 4 \mathrm{I} .800$, maar in de daaropvolgende jaren steeg dit bedrag echter weer geleidelijk tot $€ 51.800$ in 2007, waarna dit hoge niveau ondanks de economische malaise in de jaren 2008 en 2009 werd gehandhaafd.

\section{Figuur 4.7}

Ontwikkeling gemiddelde totale opleidingskosten per bedrijf ( $€$, linkeras) en gemiddeld loonsompercentage (\%, rechteras)

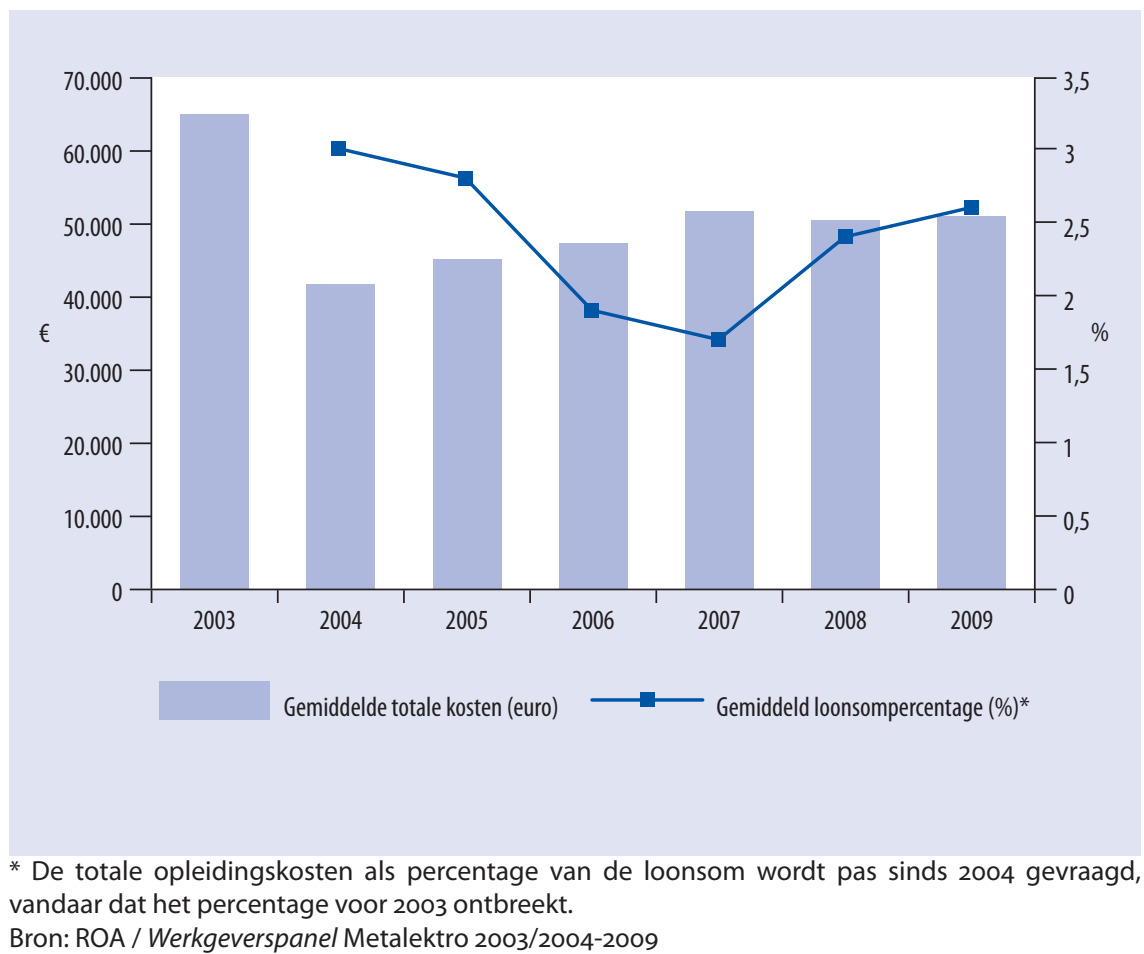

De opleidingskosten als percentage van de loonsom bedroegen in $20092,6 \%$; een lichte stijging ten opzichte van 2008, toen bedrijven nog $2,4 \%$ van de loonsom aan opleidingen besteedden. Qua ontwikkeling lijkt het gemiddelde loonsompercentage opvallend genoeg een omgekeerde ontwikkeling te volgen ten opzichte van de gemiddelde totale kosten: in de jaren waarin de gemiddelde kosten stegen, daalde het gemiddelde loonsompercentage. Vooral tussen 2005 en 2006 daalde dit gemiddelde loonsompercentage fors: van 2,8\% naar I,9\%. Vanaf 2007 is het loonsompercentage 
weer gestegen. De omgekeerde ontwikkeling van beide indicatoren van opleidingskosten wijst er op dat de conjuncturele fluctuaties in de trainingskosten minder sterk zijn dan de fluctuaties in de factoren die de ontwikkeling van de loonsom bepalen, dat wil zeggen de omvang van het personeel en de salarisontwikkeling.

De gemiddelde opleidingskosten per getrainde werknemer waren in $2009 €$ I.I70. Dit is min of meer hetzelfde bedrag als in 2008 , toen het gemiddeld $€$ I.I55 was. In 2007 was dit bedrag nog veel hoger: $€ 2.000$. Het gemiddeld aantal opleidingsdagen per werknemer is in 2009 weer toegenomen ten opzichte van 2008. In 2008 was dit gemiddelde aantal opleidingsdagen nog afgenomen van 9 (2007) naar 6 dagen per jaar. In 2009 is dit aantal echter weer toegenomen tot gemiddeld 8 dagen per jaar. Ten opzichte van 2008 worden er duidelijk weer meer technische werknemers getraind, maar dit gebeurt grotendeels met een even groot budget als in 2008. De gevolgen van de crisis laten zich nog steeds voelen: er is meer tijd, maar minder geld om te trainen, waardoor er vooral meer werknemers intern worden bijgeschoold, liefst zonder te hoge kosten.

\section{Inhoud opleidingsactiviteiten}

Figuur 4.8 laat zien welke trainingen en cursussen er in 2009 gevolgd zijn en aan welke trainingen en cursussen de metalektrobedrijven in de toekomst meer aandacht willen besteden. Opleidingen met vaktechnische vaardigheden blijven de belangrijkste cursussen. Ruim $90 \%$ van de bedrijven laat hun werknemers trainingen in vaktechnische vaardigheden volgen en $75 \%$ van de bedrijven zegt hier in de toekomst meer aandacht aan te willen besteden. Ook worden er veel cursussen leidinggeven, communicatieve vaardigheden en veilig gedrag gevolgd. Ongeveer $35 \%$ van de bedrijven laat hun werknemers dergelijke trainingen volgen. Cursussen werken met computer/IT worden door werknemers van bijna 30\% van de bedrijven gevolgd, terwijl bij IO\% tot I $6 \%$ van de bedrijven werknemers cursussen taalvaardigheden, procesgericht werken, werken in teamverband, commerciële vaardigheden, plannen en organiseren, en probleemoplossend vermogen volgen.

Waaraan denken de metalektrobedrijven, naast de opleidingen die gericht zijn op het up-to-date houden van de vaktechnische vaardigheden, in de toekomst meer aandacht te gaan besteden? Bijna $40 \%$ van de bedrijven wil in de toekomst meer aandacht besteden aan de cursussen probleemoplossend vermogen en communicatieve vaardigheden. 30\% wil meer aandacht geven aan cursussen veilig gedrag. Daarnaast zijn er ook bij nogal wat bedrijven plannen om in de toekomst meer aandacht te geven aan cursussen werken in teamverband, plannen en organiseren en leidinggeven. Interessant is ook om te zien dat het merendeel van de gevolgde cursussen en trainingen gericht is op het verbeteren van de competenties die vereist zijn voor de functie waarin iemand op dat moment werkzaam is. Ruim driekwart van de cursussen die door het technisch personeel werden gevolgd, waren gericht op hun huidige functie. Daarnaast worden er vooral cursussen gevolgd die loopbaanstappen binnen het eigen 
bedrijf mogelijk maken: $2 \mathrm{I} \%$ van de gevolgde cursussen was gericht op de verdere loopbaan van de werknemer binnen het bedrijf. Daarentegen was slechts $3 \%$ van de cursussen mede gericht op de verdere loopbaan van de werknemer buiten het bedrijf.

\section{Figuur 4.8}

Inhoud van de gevolgde trainingen en cursussen en de opleidingen waaraan het bedrijf in de toekomst meer aandacht wil besteden(\% bedrijven)

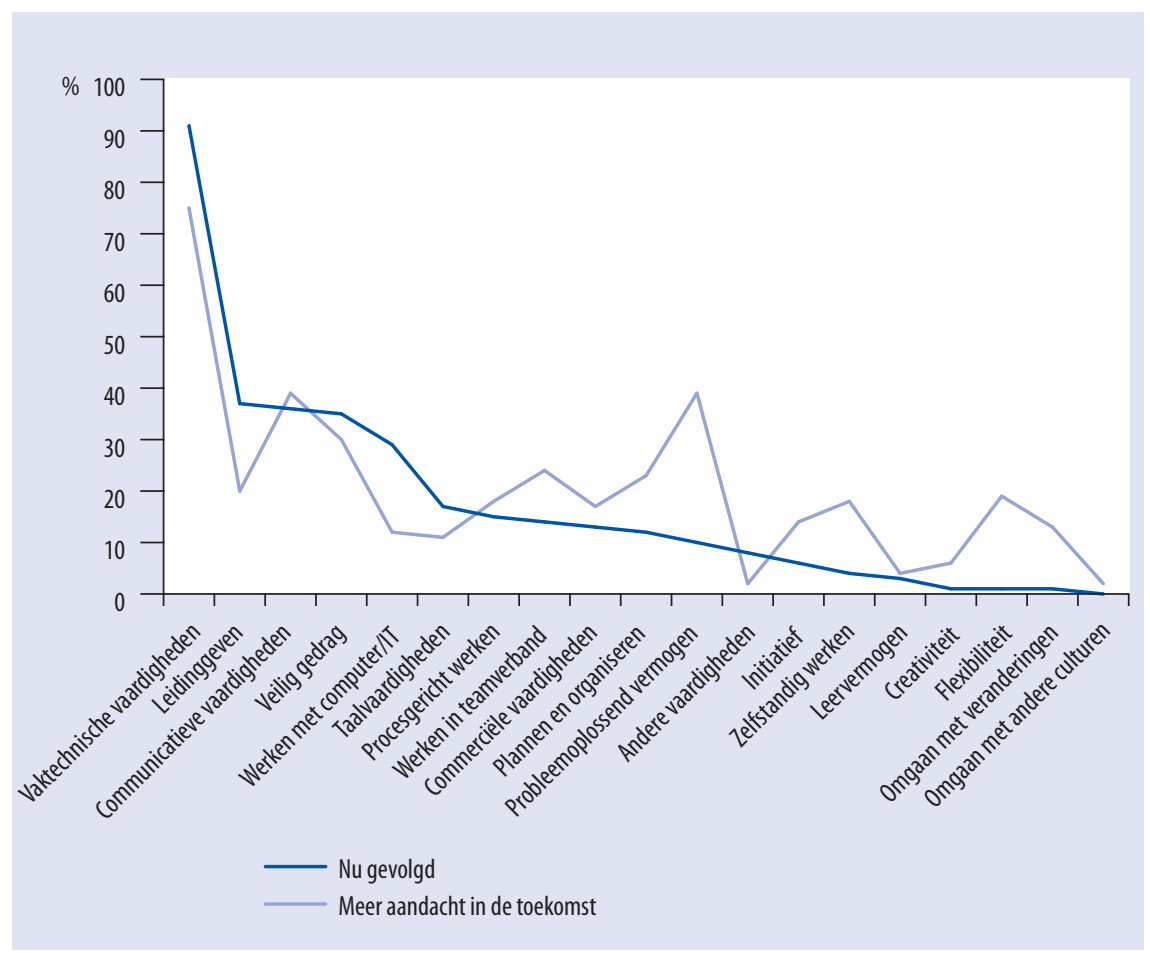

Bron: ROA / Werkgeverspanel Metalektro

\section{Initiatief voor opleiding}

In de meeste gevallen neemt de leidinggevende van het technisch personeel nog steeds het initiatief bij de deelname aan opleidingsactiviteiten. Bij $49 \%$ van de bedrijven is dit het geval. Dit is wel een behoorlijke afname ten opzichte van 2008. Toen was bij $62 \%$ van de bedrijven vooral de direct leidinggevende de initiatiefnemer van de opleidingsactiviteiten. De werknemer zelf neemt ten opzichte van 2008 even vaak het initiatief om aan opleidingsactiviteiten deel te nemen: bij 22\% van de bedrijven gebeurt dit. Bij $29 \%$ van de bedrijven neemt het moederbedrijf of de bedrijfsvestiging het initiatief bij het opleiden van het technisch personeel. Het moederbedrijf of de bedrijfsvestiging neemt daarmee veel vaker dan in 2008 het initiatief. Toen gebeurde dit nog slechts bij I6\% van de bedrijven in de Metalektro. Waarschijnlijk heeft de 
crisis veel bedrijven op corporate niveau aangezet om hun personeel te scholen, omdat er veel tijd en weinig werk beschikbaar was.

\section{Belemmeringen die bedrijven ervaren bij opleiden}

Uit figuur 4.6 bleek dat in $200933 \%$ van het technisch personeel een interne cursus of training heeft gevolgd, terwijl $19 \%$ een externe opleiding volgde. Gezien de (grote) veranderingen die zich in veel functies voordoen (zie figuur 4.2) kan men zich afvragen of bedrijven bij het opleiden van hun technisch personeel belemmeringen ervaren waardoor er niet meer werknemers worden getraind. Figuur 4.9 geeft een overzicht van de belemmeringen die voordoen.

\section{Figuur 4.9}

Belemmeringen voor de deelname aan trainingen of opleidingen ( $\%$ bedrijven)

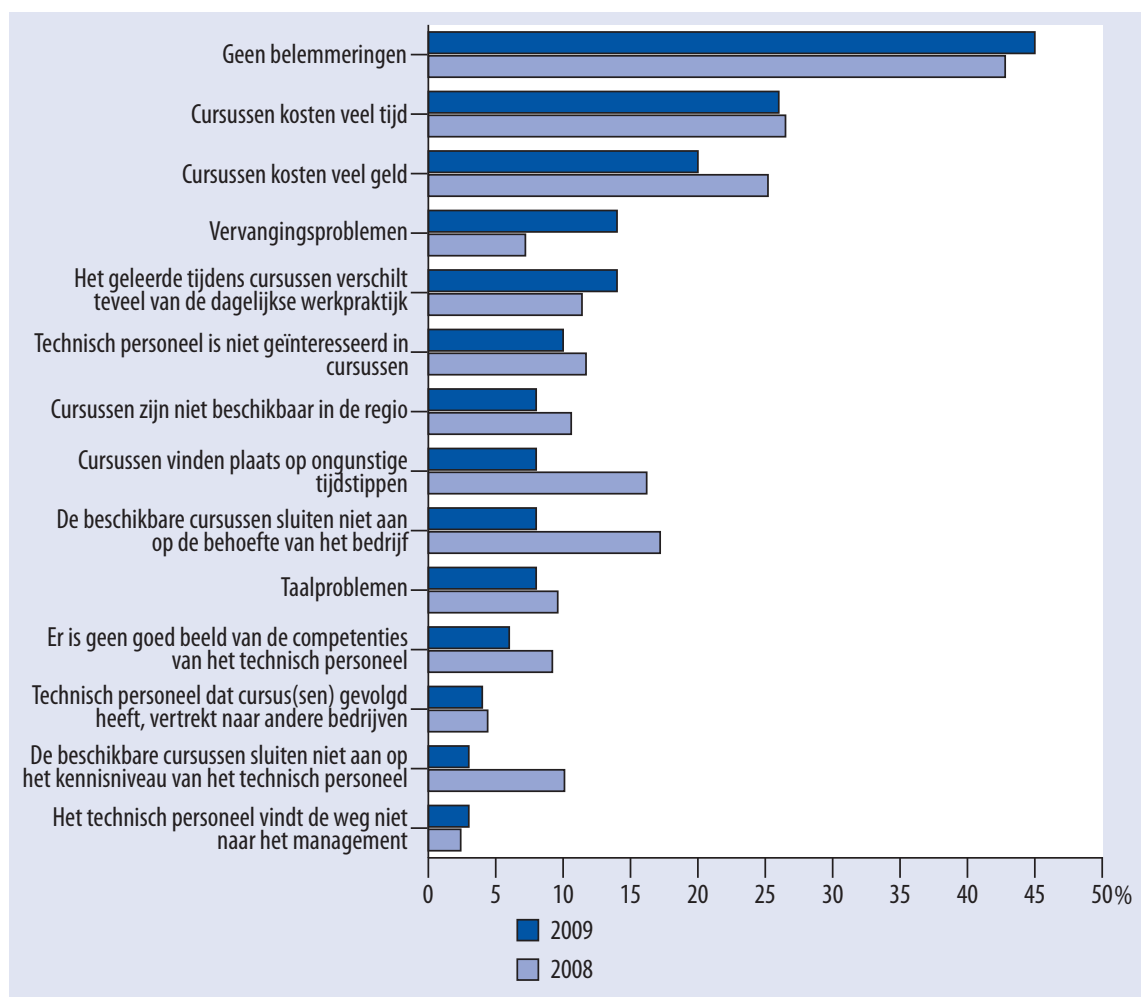

Bron: ROA / Werkgeverspanel Metalektro 2008-2009

De figuur laat zien dat $45 \%$ van de bedrijven in 2009 geen enkele belemmering ervaart bij het opleiden van hun technisch personeel. Dit percentage is vergelijkbaar met dat van 2008 . Veruit de vaakst genoemde belemmeringen zijn, net als in 2008 , dat cursussen veel tijd $(26 \%)$ en veel geld $(20 \%)$ kosten. De kostenbelemmering wordt 
overigens wel minder vaak genoemd dan in 2008 , toen $25 \%$ van de bedrijven deze belemmering noemde. $\mathrm{Bij}$ I4\% van de bedrijven wordt de scholingsdeelname van het technisch personeel belemmerd omdat het verschil tussen wat er in cursussen wordt geleerd en de dagelijkse praktijk van het werk te groot is. Ook vervangingsproblemen worden door $\mathrm{I} 4 \%$ van de bedrijven als belemmering voor de deelname aan trainingen of opleidingen genoemd. In 2008 noemde nog maar 7\% van de bedrijven vervangingsproblemen als een belemmering voor de scholingsdeelname van het technisch personeel. Sommige belemmeringen kwamen in 2008 vaker voor dan in 2009. Zo gaf in $20098 \%$ van de bedrijven aan dat de beschikbare cursussen niet op de behoefte van het bedrijf aansluiten en dat de cursussen op ongunstige tijdstippen plaatsvinden. In 2008 noemde twee keer zoveel bedrijven deze belemmeringen. De aansluiting van cursussen op het kennisniveau van het technisch personeel lijkt nauwelijks nog een punt te zijn: in 2008 noemde nog één op de tien bedrijven deze belemmering; in 2009 nog maar $3 \%$.

\section{Stimuleren van opleidingsdeelname door bedrijven}

Ondanks de belemmeringen die er soms zijn om het technisch personeel bepaalde opleidingen te laten volgen, proberen metalektrobedrijven vaak ook hun medewerkers te stimuleren om aan opleidingsactiviteiten deel te nemen. Figuur 4.Io laat een overzicht van deze inspanningen zien. Veruit de belangrijkste manier om de deelname aan opleidingsactiviteiten te stimuleren is, net als in 2008, in functioneringsgesprekken meer aandacht te besteden aan opleiding en ontwikkeling. $7 \mathrm{I} \%$ van de bedrijven probeert de deelname aan cursussen en trainingen op deze manier te stimuleren. In 2008 was dit nog $76 \%$. Net als in 2008 was ook in 2009 de als tweede vaakst genoemde reden direct leidinggevenden leren om coachend leiding te geven. In zowel 2008 als 2009 deed ongeveer de helft van de bedrijven dit. Andere relatief vaak genoemde stimuleringsmaatregelen zijn extra inspanningen van $\mathrm{P} \& \mathrm{O}(33 \%)$ en stimuleren dat werknemers elkaar enthousiast maken voor opleiding en ontwikkeling (31\%). Opvallend genoeg worden bijna alle manieren om de deelname aan opleidingsactiviteiten door technische werknemers te stimuleren in 2009 (iets) minder vaak genoemd dan in 2008. Een uitzondering hierop is het creëren van een leerrijke werkomgeving. In 2009 gaf $23 \%$ van de bedrijven aan dat ze op deze manier de opleidingsdeelname willen stimuleren. In 2008 was dat nog maar bij I8\% van de bedrijven het geval. I4\% van de bedrijven zegt geen enkele activiteiten te hebben waarmee zij de opleidingsdeelname van hun technische werknemers proberen te stimuleren. 


\section{Figuur 4.10}

Manieren waarop bedrijven de deelname aan opleidingsactiviteiten van technische werknemers proberen te stimuleren (\% bedrijven)

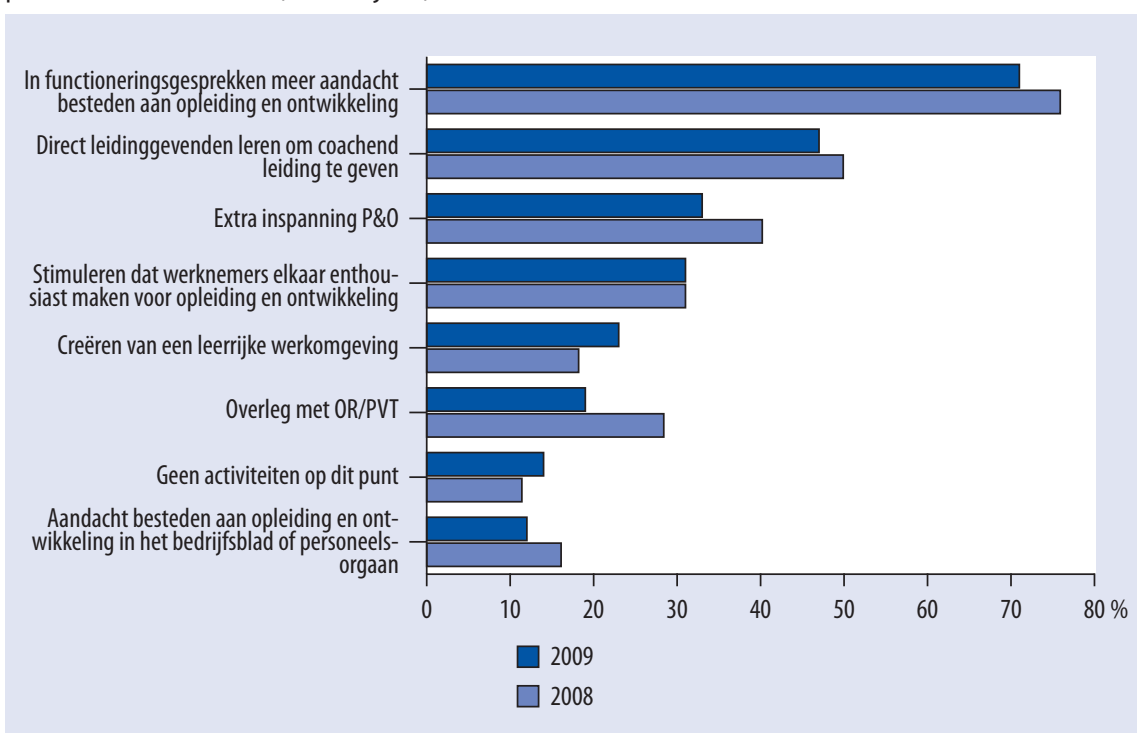

Bron: ROA / Werkgeverspanel Metalektro 2008-2009

\subsection{Ontwikkeling competenties door interne mobiliteit}

Hoewel scholing de geijkte weg lijkt om competenties te ontwikkelen, moet vooral niet vergeten worden dat learning-on-the-job, oftewel het informele leren, ook een uiterst effectieve manier kan zijn om competenties te ontwikkelen. Dit geldt vooral voor de gedragsmatige competenties uit de POFI+ agenda (probleemoplossend vermogen, omgaan met veranderingen, omgaan met klanten, flexibiliteit en initiatief). Figuur 4.2 heeft laten zien dat bedrijven nu en in de toekomst veel belang hechten aan deze competenties.

Door werknemers intern te laten doorstromen naar een andere functie (zowel in verticale als in horizontale richting) kunnen zij 'on the job' veel kennis en vaardigheden opdoen. Figuur 4.II toont de doorstroom of interne mobiliteit binnen metalektrobedrijven van technisch personeel. Het percentage bedrijven met technici die intern zijn doorgestroomd naar een andere technische functie is in 2009 sterk gedaald ten opzichte van 2008: van $62 \%$ van de bedrijven in 2008 naar slechts $34 \%$ van de bedrijven in 2009. Deze daling wordt niet gecompenseerd door een toename van het aandeel bedrijven dat technici laat doorstromen naar niet-technische functies. Deze doorstroom is immers al jaren constant op een relatief laag niveau. Het heeft er dus alle schijn van dat de economische crisis een remmend effect heeft op de interne mobiliteit binnen metalektrobedrijven. 


\section{Figuur 4.11}

Interne mobiliteit van het technisch personeel (\% bedrijven)

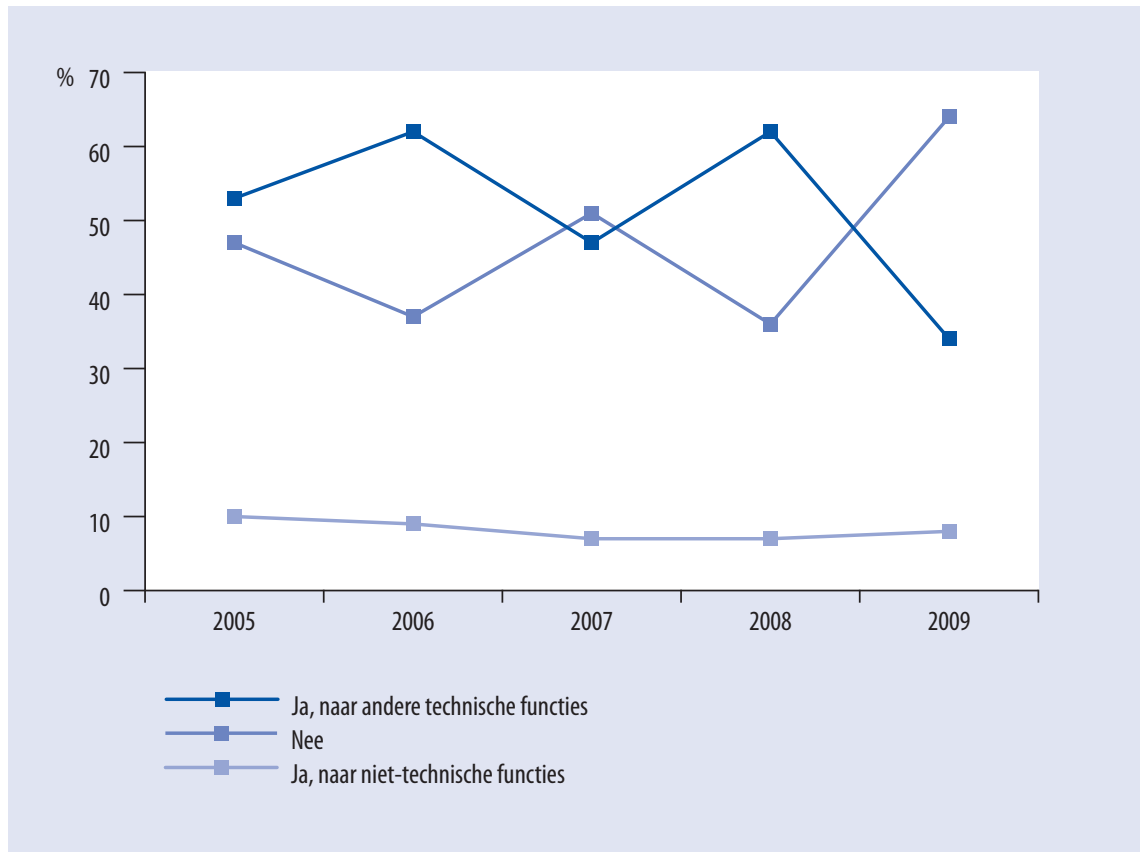

Bron: ROA / Werkgeverspanel Metalektro 2005-2009

De doorstroom van de ene naar de andere technische functie betekent meestal dat de betreffende technici in een functie op een hoger niveau terechtkomen. Dit is bij $72 \%$ van de bedrijven het geval (zie figuur 4.I2). In $58 \%$ van de bedrijven is er sprake van horizontale interne mobiliteit op het hetzelfde functieniveau, terwijl in $12 \%$ van de bedrijven technici doorstromen naar een technische functie op een lager niveau dan zij eerst hadden. Een vergelijking tussen deze cijfers van 2009 en die van voorgaande jaren laat zien dat er in 2009 in minder bedrijven sprake is van een doorstroom naar functies op een hoger niveau dan in 2007 en 2008. Daarentegen is het percentage bedrijven waar technici overstappen naar een technische functie op hetzelfde of een lager niveau in 2009 gestegen ten opzichte van de twee voorgaande jaren. De interne mobiliteit van technici naar technische functies komt dus niet alleen minder voor dan in het voorgaande jaar (zie figuur 4.II), maar deze mobiliteit is ook minder vaak in opwaartse richting. Vaker dan voorheen moeten technici bij functieveranderingen genoegen nemen met een technische functie op hetzelfde of zelfs op een lager niveau. 


\section{Figuur 4.12}

Interne mobiliteit van het technisch personeel naar functieniveau (\% bedrijven met doorstroom tussen technische functies)

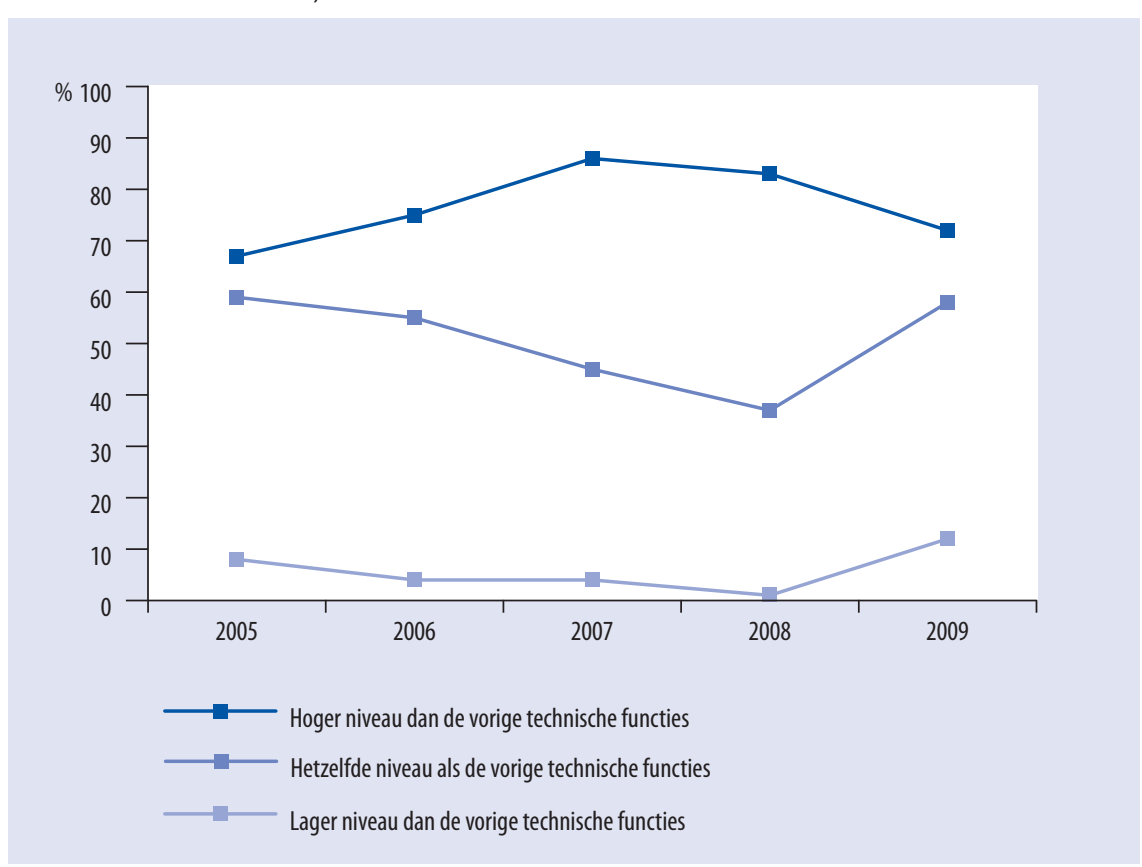

Bron: ROA / Werkgeverspanel Metalektro 2005-2009

De totale doorstroom van technici naar zowel technische als niet-technische functies is overigens geheel naar wens van de meeste bedrijven: negen van de tien bedrijven vindt dat de doorstroom zich op het gewenste niveau bevindt. De rest van de bedrijven vindt de interne mobiliteit van haar technici te laag.

\section{Doorstroom van toptechnici naar leidinggevende posities: bezint eer gij begint}

Het is van belang om goed te kijken naar de geschiktheid van een persoon voor hij/zij naar een leidinggevende wordt gepromoveerd. Dit lijkt een open deur, maar toch blijkt dat diverse bedrijven aan den lijve hebben ondervonden dat de beste techneut lang niet altijd de beste manager is. Niet zelden leidt een dergelijke opwaartse promotie van iemand die daar de juiste kwaliteiten voor ontbeert tot verlies voor zowel de techneut als het bedrijf. Een assessment voorafgaand aan een dergelijke promotie kan betrokkenen een dergelijk verlies besparen.

\subsection{Loopbaanmanagementinstrumenten: een totaaloverzicht}

In de voorgaande paragrafen zijn verschillende aspecten van het ontwikkelen van de loopbaan van werknemers in de Metalektro nader belicht, met name de scholingsdeel- 
name en de interne mobiliteit. Om het plaatje completer te maken, komen in deze paragraaf ook enkele andere aspecten van loopbaanmanagement aan de orde. Figuur 4.I3 geeft een overzicht van de HRM-instrumenten die in de periode 2006-2009 in de Metalektro zijn ingezet. Daarbij zijn de HRM-instrumenten ingedeeld naar hun plaats in het loopbaanmanagementproces.

Een kwart van de metalektrobedrijven doet bewust aan loopbaanplanning. Dit aandeel is de afgelopen drie jaar vrijwel constant gebleven. Zoals al eerder werd besproken in paragraaf 4.I, worden de instrumenten die geschikt zijn voor het bepalen van het huidige competentieniveau (Assessment) steeds vaker gebruikt. De toename van deze assessments had in het afgelopen jaar met name betrekking op EVC. Externe centra voor loopbaanadvies of mobiliteit worden daarentegen nauwelijks ingezet.

\section{How to EVC?}

De economische crisis heeft diverse metalektrobedrijven gestimuleerd om EVC-trajecten voor hun personeel op te starten, veelal in het kader van de wtv en/of de deeltijd-WW. Bedrijven die deze trajecten zijn gestart geven aan dat het hun medewerkers erkenning oplevert van wat ze al kunnen en kennen door het leren in de praktijk zowel binnen als buiten het werk. Andere bedrijven zijn nog wat huiverig voor het gebruik van EVC door de soms negatieve lading die het heeft als zijnde een voorportaal van ontslag. Het is dan ook van groot belang dat bedrijven duidelijk naar hun werknemers communiceren wat zij met EVC-trajecten willen bereiken.

EVC-trajecten zijn niet uniform en kunnen dus qua inhoud en kwaliteit verschillen tussen de aanbieders van EVC. Om de afnemers van EVC-trajecten te helpen bij het scheiden van kaf en koren is een accreditatie van EVC-aanbieders ingevoerd. Het onderling uitwisselen van ervaringen met EVC-aanbieders kan metalektrobedrijven ook behoeden voor negatieve ervaringen zoals trajecten die veel langer duren dan gewenst of die qua inhoud niet aansluiten bij de behoefte. Het vooraf maken en vastleggen van duidelijke afspraken met EVC-aanbieders kan een EVC-traject aanmerkelijk succesvoller maken.

Naast de verwachte veranderingen in de functies, organisatiedoelen en wensen van de werknemer (zie paragraaf 4.I), vormen de uitkomsten van een assessment een belangrijke input voor het bepalen van de competenties die een werknemer zich nog moet verwerven om zijn employability op peil te houden. Als deze competenties zijn bepaald, dient te worden afgesproken op welke wijze en op welke termijn, deze competenties moeten worden ontwikkeld. Aangezien papier (of de computer) geduldig is, is het aan te raden al wat in het voorgaande is vastgesteld en afgesproken (huidige competenties, gewenste competenties, acties, termijnen) vast te leggen. Ook hiervoor bestaan verschillende, elkaar soms aanvullende, instrumenten. Op bedrijfsniveau zijn er de bedrijfsopleidingsplannen die in meer dan de helft van de metalektrobedrijven gebruikt worden. Op individueel niveau kunnen persoonlijke opleidingsplannen (POP's) worden gebruikt en dit gebruik heeft het afgelopen jaar een behoorlijke vlucht genomen: in 2009 gebruikte $58 \%$ van de bedrijven POP's voor hun 
werknemers tegenover $4 \mathrm{I} \%$ in 2008 . Daarnaast gebruikt één van de vijf bedrijven een competentie managementsysteem.

Een veelgebruikte manier om werknemers zich de juiste competenties eigen te laten maken, is het volgen van aanvullende scholing. Zoals figuur 4.I3 laat zien, bieden vier van de vijf bedrijven in 2009 opleidingsfaciliteiten aan; een toename ten opzichte van de voorgaande jaren. Verder gaat in 2009 driekwart van de bedrijven met haar werknemers in gesprek over hun scholing en ontwikkeling. Ook dit is een lichte toename ten opzichte van de voorgaande jaren. Zeer waarschijnlijk zijn deze toenames mede het gevolg van het stimuleringsbeleid dat de overheid, sociale partners en $\mathrm{A}+\mathrm{O}$ fonds als reactie op de economische crisis heeft ingesteld.

\section{Figuur 4.13}

HRM/Loopbaanmanagementinstrumenten (\% bedrijven)

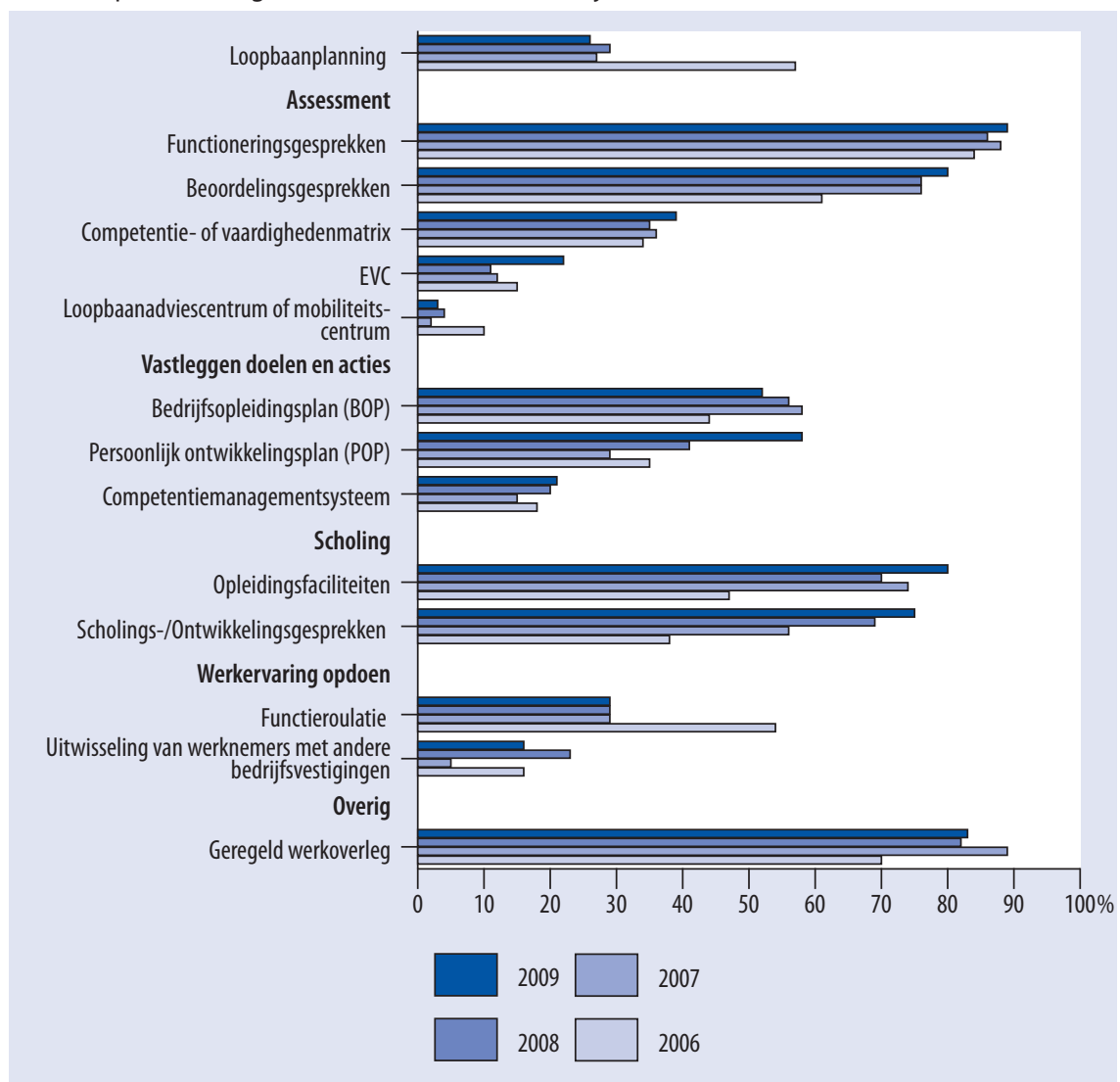

Bron: ROA / Werkgeverspanel Metalektro 2006-2009

Naast scholing is ook learning-on-the-job een belangrijke methode om competenties te verwerven. Het intern doorstromen naar een andere functie is een manier om 
werkenderwijs te leren (zie paragraaf 4.4). Deze interne doorstroom is echter niet altijd mogelijk of gewenst. Een andere manier om werkenderwijs te leren is via functieroulatie of een uitwisseling van werknemers met andere vestigingen. In 2009 komt functieroulatie structureel in bijna $30 \%$ van de bedrijven voor en uitwisseling van werknemers in ongeveer $15 \%$ van de bedrijven.

In deze paragraaf is gekeken naar de instrumenten zoals ze in de afgelopen jaren zijn ingezet. Aan bedrijven is ook gevraagd welke instrumenten zij in de komende jaren denken te gaan gebruiken. Deze toekomstplannen ten aanzien van HRM/loopbaaninstrumenten zullen worden toegelicht in paragraaf 4 van hoofdstuk 7. 


\section{Sociale innovatie}

In metalektrobedrijven is er van oudsher veel plaats voor technologische innovaties. De laatste jaren is er echter ook steeds meer aandacht voor niet-technologische oftewel sociale innovaties. De eerste twee paragrafen gaan in op sociale innovatie op het gebied van organisatie en management. In paragraaf S.I wordt ingegaan op het implementatieproces van deze innovaties, waarna in paragraaf 5.2 wordt vooruitgekeken naar de komende jaren. Vervolgens passeren het menselijk kapitaal (paragraaf 5.3) en de externe samenwerking (paragraaf 5.4) de revue.

\subsection{Organisatie en management: implementatie}

Sociale innovatie heeft als voornaamste doel de bedrijfsprestaties te verbeteren en de talenten van de medewerkers te ontplooien en betreft veranderingen op het gebied van:

- Organisatie en management: innovaties die vooral betrekking hebben op de manier waar op het werk en de verantwoordelijkheden worden georganiseerd en hoe het bedrijf door het management wordt geleid.

- Het menselijk kapitaal van het bedrijf: innovaties waardoor het menselijk kapitaal beter kan worden benut binnen het bedrijf en innovaties waardoor dit kapitaal verder ontwikkeld kan worden.

- Nieuwe vormen van samenwerking in de bedrijfsomgeving: allianties met andere bedrijven, samenwerking met leveranciers, klanten en kennisorganisaties.

In deze paragraaf gaan we in op de vernieuwingen op organisatorisch en managementgebied die door de metalektrobedrijven in het recente verleden zijn geïmplementeerd. In de volgende paragraaf wordt de blik op de toekomst gericht: de geplande innovaties met betrekking tot organisatie en management komen aan bod, met speciale aandacht voor de specifieke doelen die bedrijven hiermee willen bereiken.

\section{Externe feedback meet effect van sociale innovatie}

De effecten van sociale innovatieprojecten zijn niet altijd eenvoudig te meten. Eén van de geïnterviewde metalektrobedrijven leest de effectiviteit van haar sociale innovatieprojecten af aan de spontane feedback die men ontvangt van nieuwe medewerkers en bezoekers (klanten, leveranciers, etc.) over wat zij ervaren in het bedrijf. 
De metalektrobedrijven zijn in 2009 actiever geweest op het gebied van organisatorische veranderingen dan in 2008: 91\% van de bedrijven voerde één of meerdere organisatorische veranderingen door. Daarbij werden er per bedrijf gemiddeld maar liefst bijna vier veranderingen doorgevoerd. Figuur 5.I laat zien dat $58 \%$ van de bedrijven serieus aan de slag is gegaan met een innovatiegerichte strategie. Ook zet $54 \%$ van de bedrijven het personeel variabel(er) in door middel van flexibele werktijden, deeltijdwerk, etc. Projectmatig werken is een veelvoorkomende organisatorische verandering: maar liefst $49 \%$ van metalektrobedrijven heeft zich deze vorm van werken vorig jaar eigen gemaakt of heeft er in ieder geval een begin mee gemaakt. Dergelijke sociale innovaties hebben vaak een doorlooptijd die langer is dan een jaar: sommige bedrijven geven dan ook aan dat de implementatie nog niet is afgerond. Daarnaast hebben ongeveer vier op de tien bedrijven multifunctionele teams en/of andere vormen van teamgericht werken geïntroduceerd. Evenveel bedrijven zijn taken over de afdelingen heen gaan integreren.

In 2009 is er voor verschillende sociale innovaties meer aandacht geweest dan in 2008 . Zo is het aantal bedrijven met innovaties gericht op het verminderen van managementlagen, de taakintegratie over afdelingen, andere vormen van teamgericht werken, de variabele inzet van personeel, decentraliseren en centraliseren in 2009 toegenomen met 5-Io procentpunten. Het gebruik van een innovatiegerichte strategie is zelfs in procentpunten verdubbeld ten opzichte van 2008.

\section{Figuur 5.1}

Organisatorische veranderingen geïmplementeerd (\% van de bedrijven)

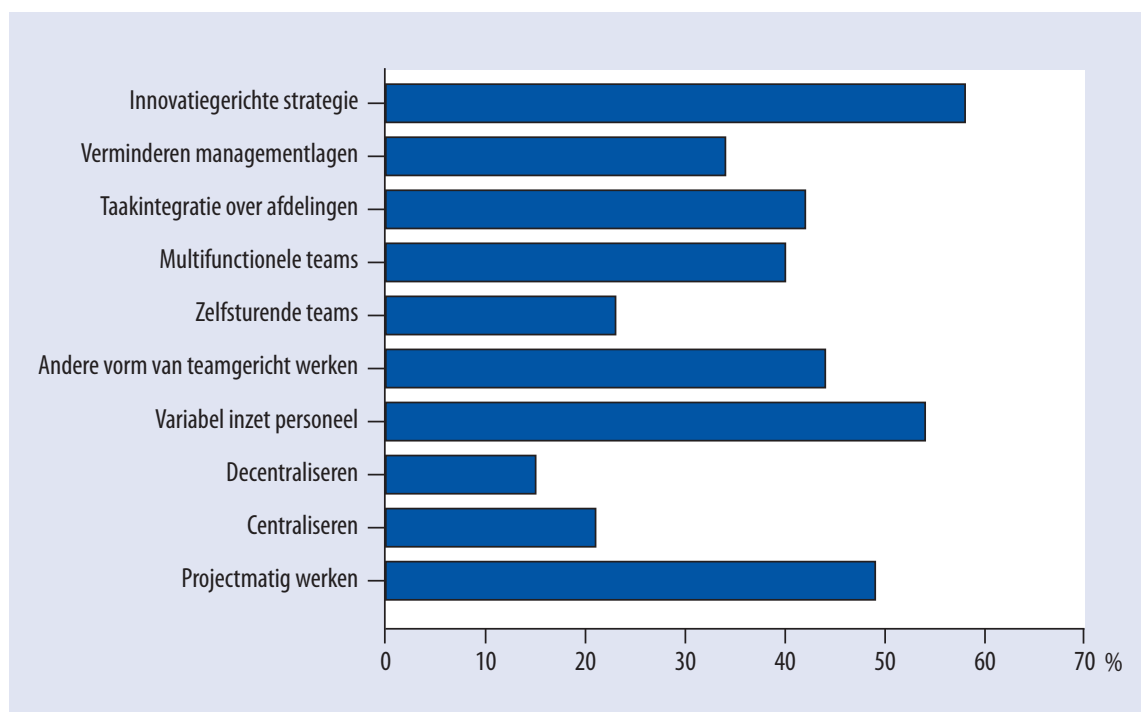

Bron: ROA/Werkgeverspanel Metalektro 2009 


\section{Organisatorische veranderingen geëvalueerd}

Sinds enkele jaren wordt in de Arbeidsmarktmonitor Metalektro onderzoek gedaan naar de organisatorische veranderingen die door metalektrobedrijven worden geïmplementeerd. Maar hoe verloopt het implementatieproces eigenlijk en wat is de huidige status van dergelijke veranderingen? Om dit te onderzoeken zijn hierover vragen gesteld in de meest recente vragenlijst. Uit de antwoorden van de bedrijven op deze vragen blijkt dat het gros van de vernieuwingen naar wens verloopt: bij $78 \%$ van de metalektrobedrijven is de implementatie van de organisatieveranderingen die in 2009 zijn doorgevoerd naar wens verlopen. Echter, $8 \%$ van de veranderingen werd volgens de bedrijven bemoeilijkt door een tekort aan kennis en vaardigheden bij het personeel, $6 \%$ door tijdgebrek en $4 \%$ door gebrek aan menskracht. Gebrek aan geld of draagkracht speelde slechts bij enkele implementaties een belemmerende rol.

\section{Figuur 5.2}

Organisatorische veranderingen waarvan de implementatie geheel volgens plan/naar wens is verlopen (\% van bedrijven die de betreffende verandering hebben doorgevoerd)

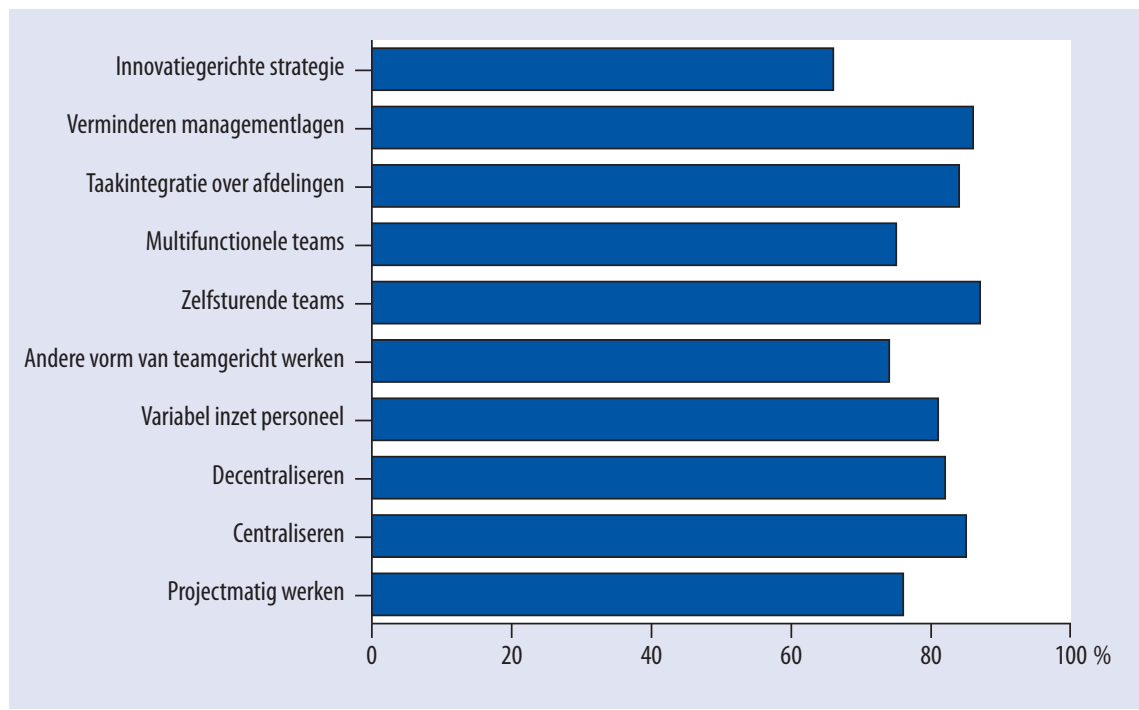

Bron: ROA/Werkgeverspanel Metalektro 2009

Uit figuur 5.2 valt op te maken dat de ene innovatie meer implementatieproblemen ondervindt dan de andere. Bij tweederde van de bedrijven die in 2009 een innovatiegerichte strategie hebben ingevoerd, is de implementatie volgens plan verlopen. Een derde ondervond echter problemen. Bedrijven die multifunctionele teams, andere vormen van teamgericht werken en projectmatig werken invoerden, zijn in drie van de vier gevallen tevreden over het implementatieproces, terwijl een kwart invoeringsproblemen had. Daarentegen hebben bedrijven die voor het eerst gingen werken met zelfsturende teams, taakintegratie over afdelingen en die sneden in het aantal 
managementlagen weinig problemen gekend bij de uitvoering van deze organisatorische veranderingen.

Eerder is al aangegeven, dat gebrekkige kennis en vaardigheden bij het personeel het vaakst als implementatiebelemmering genoemd worden, gevolgd door gebrek aan tijd en menskracht. Maar spelen deze hindernissen bij elke innovatie een even grote rol? Figuur 5.3 laat zien dat dit iets genuanceerder ligt. Personeel met te weinig kennis en vaardigheden blijkt het belangrijkste implementatie-obstakel bij het invoeren van multifunctionele teams ( $15 \%)$, andere vormen van teamgericht werken ( $15 \%)$, projectmatig werken $(9 \%)$ en taakintegratie $(8 \%)$. Tijdgebrek wordt als belangrijkste belemmering genoemd door bedrijven die een innovatiegerichte strategie hebben geïmplementeerd: één op de tien bedrijven die in 2009 een dergelijke strategie implementeerde, kampte met tijdgebrek.

\section{Figuur 5.3}

Problemen bij de implementatie van organisatorische veranderingen (\% van bedrijven die de betreffende verandering hebben doorgevoerd)

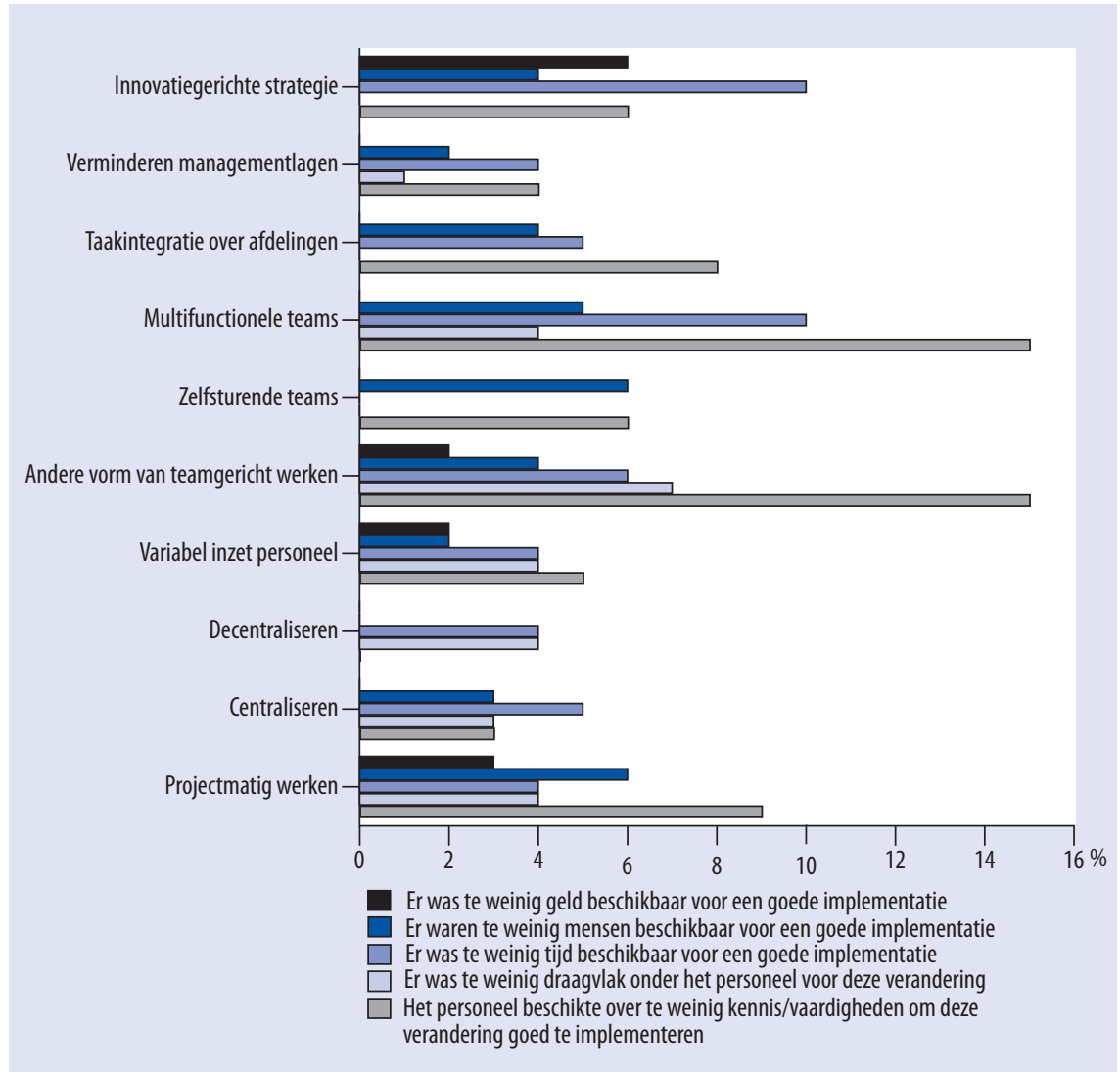

Bron: ROA/Werkgeverspanel Metalektro 2009 


\section{Huidige status van organisatorische veranderingen}

De voorgaande figuren hebben laten zien dat de implementatie van diverse innovaties op organisatorisch en managementgebied niet altijd op rolletjes loopt. Heeft dit gevolgen voor de continuïteit van dergelijke innovaties? Zijn ze nog steeds van kracht? Ook deze vragen zijn voorgelegd aan de metalektrobedrijven. Zijn de ingezette sociale innovaties nog steeds van kracht is of zijn sommige gedeeltelijk of volledig teruggedraaid.

Van alle organisatorische veranderingen die in 2009 geïmplementeerd zijn, is $90 \%$ nog steeds onverminderd van kracht. $7 \%$ is echter gedeeltelijk en $3 \%$ is volledig teruggedraaid naar de situatie van voor de verandering. Sociale innovaties als de invoering van zelfsturende teams en het projectmatig gaan werken worden zelden $(3 \%)$ ongedaan gemaakt. Het inzetten van een innovatiegerichte strategie en andere vormen van teamgericht werken sneuvelen iets vaker, maar nog altijd in minder dan Io\% van de gevallen. Bovendien gaat het dan vaak slechts om het gedeeltelijke terugdraaien van de doorgevoerde veranderingen. De introductie van multifunctionele teams, het verminderen van het aantal managementlagen en taakintegratie over afdelingen is in $10 \%$ tot $15 \%$ van de gevallen (gedeeltelijk) teruggedraaid, maar het vaakst keren bedrijven op hun schreden terug die hun personeel meer variabel zijn gaan inzetten: bijna één op de vijf bedrijven die hun personeel meer variabel ging inzetten, draaide het weer terug. De helft van deze bedrijven keerde de verandering zelfs volledig terug.

\subsection{Organisatie en management: doelen}

De bedrijven in de Metalektro zullen ook de komende jaren veel aandacht hebben voor sociale innovatie. In deze paragraaf komen de geplande organisatorische veranderingen aan bod én de doelen die de bedrijven met deze veranderingen nastreven. Figuur 5.4 laat zien dat metalektrobedrijven het meest geïnteresseerd zijn in het implementeren van een innovatiegerichte strategie. $50 \%$ van de bedrijven wil dit het komende jaar realiseren en nog eens $20 \%$ neemt daar één tot vijf jaar de tijd voor. Ongeveer $60 \%$ van de bedrijven richt haar pijlen op het variabel inzetten van het personeel en het projectmatig werken. Iets meer dan de helft van de bedrijven gaat voor multifunctionele teams en/of een andere vorm van teamgericht werken. Even veel bedrijven willen taakintegratie over afdelingen realiseren.

Om een vergelijking te maken tussen de geplande en de reeds geïmplementeerde organisatorische veranderingen (zie figuur 5.I), zijn deze beide opgenomen in figuur 5.4. Het blijkt dat het patroon van de geplande organisatorische veranderingen opvallend veel overeenkomsten vertoont met dat van de reeds geïmplementeerde veranderingen. Dit heeft deels te maken met het feit dat een aanzienlijk deel van de bedrijven de betreffende verandering in delen van het bedrijf geïmplementeerd heeft, maar van plan is deze verder uit te rollen binnen de organisatie. Zo zullen verschil- 
lende bedrijven in 2009 een sociale innovatie hebben doorgevoerd in een deel van het bedrijf als een pilot-project dat de komende jaren verder wordt uitgerold in de rest van het bedrijf. Zoals eerder reeds werd aangegeven, zegt een aantal bedrijven ook dat ze het implementatieproces van bepaalde sociale innovaties in 2009 nog niet hebben afgerond en dat dit proces dus nog doorloopt in 2010.

\section{Figuur 5.4}

Geplande versus geïmplementeerde sociale innovatie op het gebied van organisatie en management (\% bedrijven)

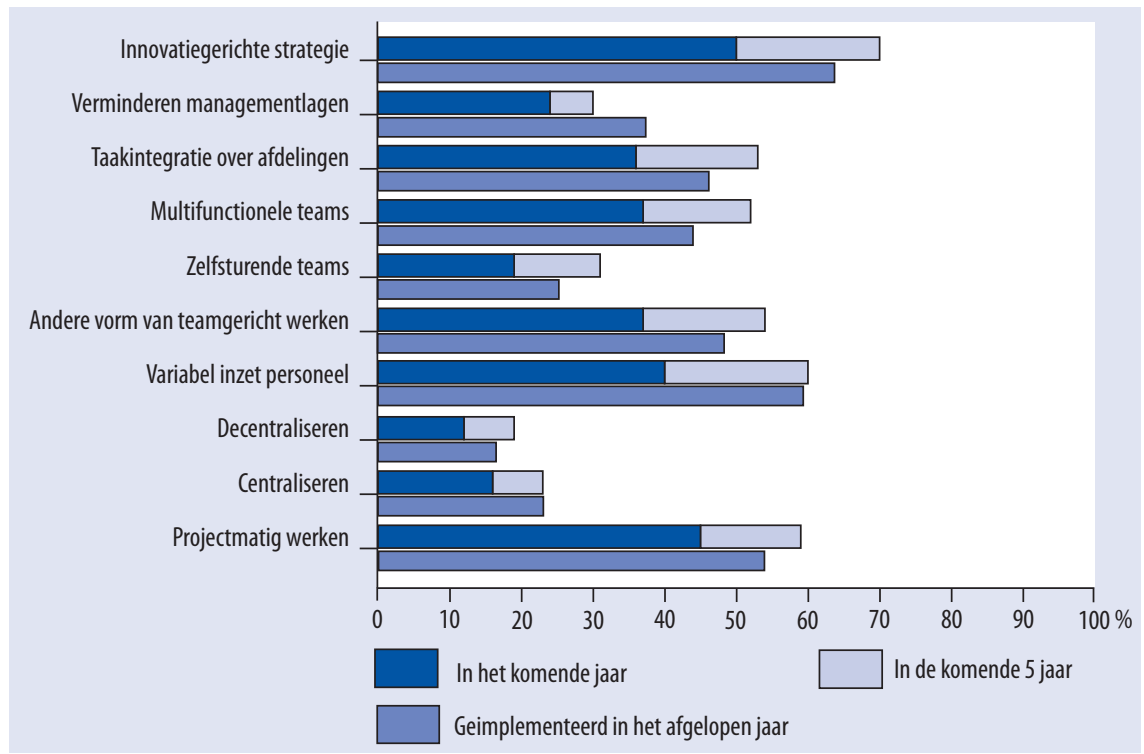

Bron: ROA/Werkgeverspanel Metalektro 2009

Met welk doel voeren de bedrijven in de Metalektro organisatorische veranderingen door? En op welke termijn verwachten ze deze doelen bereikt te hebben? Zoals te zien is in figuur 5.5, willen bedrijven vooral de productiviteit van hun werknemers verhogen en de kwaliteit van de producten verbeteren. Daarnaast is flexibilisering van de productie een veelgenoemd doel van een organisatorische innovatie. Verder blijkt uit de figuur dat het met de meeste organisatorische veranderingen mogelijk is om meerdere doelen na te streven. Figuur 5.5 laat ook zien dat veel metalektrobedrijven verwachten de beoogde doelen al binnen een jaar te kunnen realiseren, met uitzondering van de bedrijven die een innovatiegerichte strategie willen implementeren. Een dergelijke verandering van de bedrijfsstrategie vereist vanzelfsprekend een wat langere tijdshorizon. Bedrijven die een innovatiegerichte strategie implementeren zullen geduld moeten uitoefenen voordat de strategie zijn weerslag heeft gevonden in bedrijfsprocessen en ze de vruchten van deze innovatie kunnen plukken. 
Figuur 5.5

Doelstellingen van de geplande sociale innovaties op het gebied van organisatie en management, (\% bedrijven)

\begin{tabular}{|c|c|c|c|c|c|}
\hline & $\begin{array}{l}\text { Hogere } \\
\text { productiviteit } \\
\text { per werk- } \\
\text { nemer }\end{array}$ & $\begin{array}{l}\text { Kwalitatief } \\
\text { hoogwaardi- } \\
\text { gere werkge- } \\
\text { legenheid }\end{array}$ & $\begin{array}{l}\text { Kwaliteits- } \\
\text { verbetering } \\
\text { van de } \\
\text { producten }\end{array}$ & $\begin{array}{l}\text { Fexibilisering } \\
\text { van de pro- } \\
\text { ductie }\end{array}$ & $\begin{array}{l}\text { Als werk- } \\
\text { gever aan- } \\
\text { trekkelijker } \\
\text { worden }\end{array}$ \\
\hline \multicolumn{6}{|l|}{ Innovatiegerichte strategie } \\
\hline \multicolumn{6}{|l|}{ Doel in komend jaar te bereiken } \\
\hline \multicolumn{6}{|l|}{ Doel in komende vijf jaar te bereiken } \\
\hline \multicolumn{6}{|l|}{ Verminderen managementlagen } \\
\hline \multicolumn{6}{|l|}{ Doel in komend jaar te bereiken } \\
\hline \multicolumn{6}{|l|}{ Doel in komende vijf jaar te bereiken } \\
\hline \multicolumn{6}{|l|}{ Taakintegratie over afdelingen } \\
\hline \multicolumn{6}{|l|}{ Doel in komend jaar te bereiken } \\
\hline \multicolumn{6}{|l|}{ Doel in komende vijf jaar te bereiken } \\
\hline \multicolumn{6}{|l|}{ Multifunctionele teams } \\
\hline \multicolumn{6}{|l|}{ Doel in komend jaar te bereiken } \\
\hline \multicolumn{6}{|l|}{ Doel in komende vijf jaar te bereiken } \\
\hline \multicolumn{6}{|l|}{ Zelfsturende teams } \\
\hline \multicolumn{6}{|l|}{ Doel in komend jaar te bereiken } \\
\hline \multicolumn{6}{|l|}{ Doel in komende vijf jaar te bereiken } \\
\hline \multicolumn{6}{|l|}{ Andere vorm van teamgericht werken } \\
\hline \multicolumn{6}{|l|}{ Doel in komend jaar te bereiken } \\
\hline \multicolumn{6}{|l|}{ Doel in komende vijf jaar te bereiken } \\
\hline \multicolumn{6}{|l|}{ Variabele inzet personeel } \\
\hline \multicolumn{6}{|l|}{ Doel in komend jaar te bereiken } \\
\hline \multicolumn{6}{|l|}{ Doel in komende vijf jaar te bereiken } \\
\hline \multicolumn{6}{|l|}{ Decentraliseren } \\
\hline \multicolumn{6}{|l|}{ Doel in komend jaar te bereiken } \\
\hline \multicolumn{6}{|l|}{ Doel in komende vijf jaar te bereiken } \\
\hline \multicolumn{6}{|l|}{ Centraliseren } \\
\hline \multicolumn{6}{|l|}{ Doel in komend jaar te bereiken } \\
\hline \multicolumn{6}{|l|}{ Doel in komende vijf jaar te bereiken } \\
\hline \multicolumn{6}{|l|}{ Projectmatig werken } \\
\hline \multicolumn{6}{|l|}{ Doel in komend jaar te bereiken } \\
\hline Doel in komende vijf jaar te bereiken & & & & & \\
\hline
\end{tabular}

\begin{tabular}{|l|l|l|}
\hline $0-20 \%$ & $21-40 \%$ & $>40 \%$ \\
\hline
\end{tabular}

Bron: ROA/Werkgeverspanel Metalektro 2009 
Vormen van teamwerk (multifunctioneel, zelfsturende en andere vormen), taakintegratie over afdelingen en projectmatig werken worden relatief vaak ingezet om de productiviteit te verhogen, producten te verbeteren en de productie te flexibiliseren. Opvallend is dat ook het centraliseren wordt genoemd om deze doelen te bereiken. Een innovatiegerichte strategie zal naar verwachting op den duur ook bijdragen aan kwalitatief hoogwaardigere werkgelegenheid binnen het bedrijf en daarmee ook aan de aantrekkelijkheid van het bedrijf als werkgever.

De patronen die zichtbaar zijn in figuur 5.5, zijn in grote lijnen identiek aan de figuur in de vorige rapportage van de Arbeidsmarktmonitor Metalektro. Er is echter één duidelijk verschil, namelijk bij de innovatiegerichte strategie. In de vorige meting dachten nog relatief veel bedrijven dat de beoogde doelen reeds binnen een jaar bereikt zouden worden, terwijl de bedrijven nu verwachten pas in de komende vijf jaar de beoogde doelen van een dergelijk strategie te bereiken. Dit zou er ook op kunnen wijzen dat de beoogde strategische verandering meer omvattend is geworden.

\section{Hoe metalektrobedrijven zelfsturende teams optimaal laten functioneren}

Een metalektrobedrijf dat veel met teams werkt, heeft eigen mensen opgeleid met als taak teamvergaderingen procesmatig te begeleiden. Dergelijke facilitators zijn bijvoorbeeld in staat om zaken boven tafel krijgen die een open communicatie in het team in de weg staan, zodat het team deze hindernissen zelf uit de weg kan ruimen.

In een ander bedrijf heeft men met elkaar een aantal basisprincipes plus onderlinge prioritering afgesproken. Dit geeft de teams en de individuele teamleden richtlijnen op basis waarvan ze zelf de juiste beslissingen kunnen nemen. Voorbeelden van dergelijke principes kunnen zijn 'veiligheid' of 'leverbetrouwbaarheid'.

\subsection{Benutting en ontwikkeling van menselijk kapitaal}

Het op een andere manier organiseren van het werk en de aansturing van het werkproces zijn belangrijke vormen van sociale innovatie waarmee bedrijven in de Metalektro op velerlei gebieden 'winst' kunnen behalen. Paragraaf 5.I heeft echter laten zien dat de implementatie van deze organisatorische veranderingen niet altijd optimaal verloopt en dat dit vaak te maken heeft met het feit dat de kennis- en vaardigheden van het personeel niet toereikend zijn om de veranderde invulling van hun werkzaamheden volledig aan te kunnen(zie figuur 5.3). Wanneer (een deel van) het personeel over onvoldoende kennis en vaardigheden beschikt, dienen bedrijven veel aandacht te schenken aan de ontwikkeling van die kennis en vaardigheden. Dit geeft ook duidelijk aan hoe belangrijk het is om oog te hebben voor de samenhang tussen het doorvoeren van organisatorische vernieuwingen en het HRM-beleid gericht op de competentieontwikkeling van het personeel. Alleen als het personeel goed geëquipeerd is, zal een bedrijf optimaal kunnen profiteren van een bepaalde sociale innovatie. Op welke manieren het mogelijk is om de competentieontwikkeling van het 
personeel te stimuleren én hoe metalektrobedrijven dit doen, is uitgebreid besproken in hoofdstuk 4.

In deze paragraaf ligt het zwaartepunt op het zo optimaal mogelijk benutten van het menselijk kapitaal dat in het bedrijf aanwezig is. Hiervoor kijken we naar een selectie van de speerpunten van het personeelsbeleid in de komende vijf jaar. ${ }^{5}$ Zoals figuur 5.6 laat zien, gaat al enige jaren veruit de meeste aandacht uit naar het bevorderen van de inzetbaarheid van het personeel: reeds vanaf 2005 noemt driekwart van de metalektrobedrijven dit als een speerpunt van hun personeelsbeleid. Dit constant hoge percentage wijst er op dat een hoge inzetbaarheid van het personeel van groot belang is ongeacht de stand van de conjunctuur. Het bevorderen van de inzetbaarheid is vanzelfsprekend niet eenvoudig en vereist ook voortdurende aandacht. Wat dat betreft is het dan ook niet verwonderlijk dat dit door de metalektrobedrijven al jaren het vaakst genoemd wordt als speerpunt van hun personeelsbeleid. In de figuren 5.7 en 5.8 wordt verder ingegaan op de (brede) inzetbaarheid van personeel.

\section{Van ideeënbus naar idee-centraal}

Eén van de metalektrobedrijven wilde veel meer gebruik maken van de innovatiekracht onder de medewerkers door verbeterideeën meer ruimte en aandacht te geven. De traditionele ideeënbus verdween en werd vervangen door het volgende traject:

- ledereen met een verbeteridee (inclusief rendementsanalyse) kan dit idee presenteren aan een jury.

- Als het idee wordt goedgekeurd, krijgt de inbrenger van het idee geld en tijd om het idee uit te voeren. Tevens krijg de inbrenger een ideeëncoach toegewezen (een oudere collega die het bedrijf goed kent). 0ok gaat de inbrenger, indien nodig, ter plaatse kijken in bijvoorbeeld een fabriek van een leverancier.

- Indien een idee omvangrijke veranderingen met zich meebrengt, wordt de uitvoering van het idee uitgevoerd door een projectteam waarvan de inbrenger van het idee deel uit maakt.

Naast het bevorderen van de inzetbaarheid van het personeel, wil bijna de helft van de bedrijven coachend leiderschap bevorderen, terwijl voor $29 \%$ van de bedrijven het ontwikkelen van een leeftijdsbewust personeelsbeleid een speerpunt is van hun personeelsbeleid. Hoewel het belang van een leeftijdsbewust personeelsbeleid veelal zal zijn ingegeven door de huidige vergrijzing van het personeelsbestand van veel bedrijven, is het natuurlijk ook op de lange termijn van groot belang doordat het personeel de komende decennia waarschijnlijk op steeds latere leeftijd met pensioen zal gaan. Bovendien is het van belang om te beseffen dat een leeftijdsbewust personeelsbeleid niet alleen gericht moet zijn op de oudere medewerkers, maar ook op de medewerkers van middelbare leeftijd en de jongere medewerkers. Waar het bij een leeftijdsbewust

5. Een overzicht van alle speerpunten van het toekomstig personeelsbeleid van metalektrobedrijven wordt besproken in paragraaf 7.4 . 
personeelsbeleid kennelijk om gaat, is het (h)erkennen van de verschillende behoeften en mogelijkheden van werknemers van verschillende leeftijden. ${ }^{6}$

\section{Figuur 5.6}

Speerpunten toekomstig HRM-beleid gericht op optimale benutting personeel (\% bedrijven)

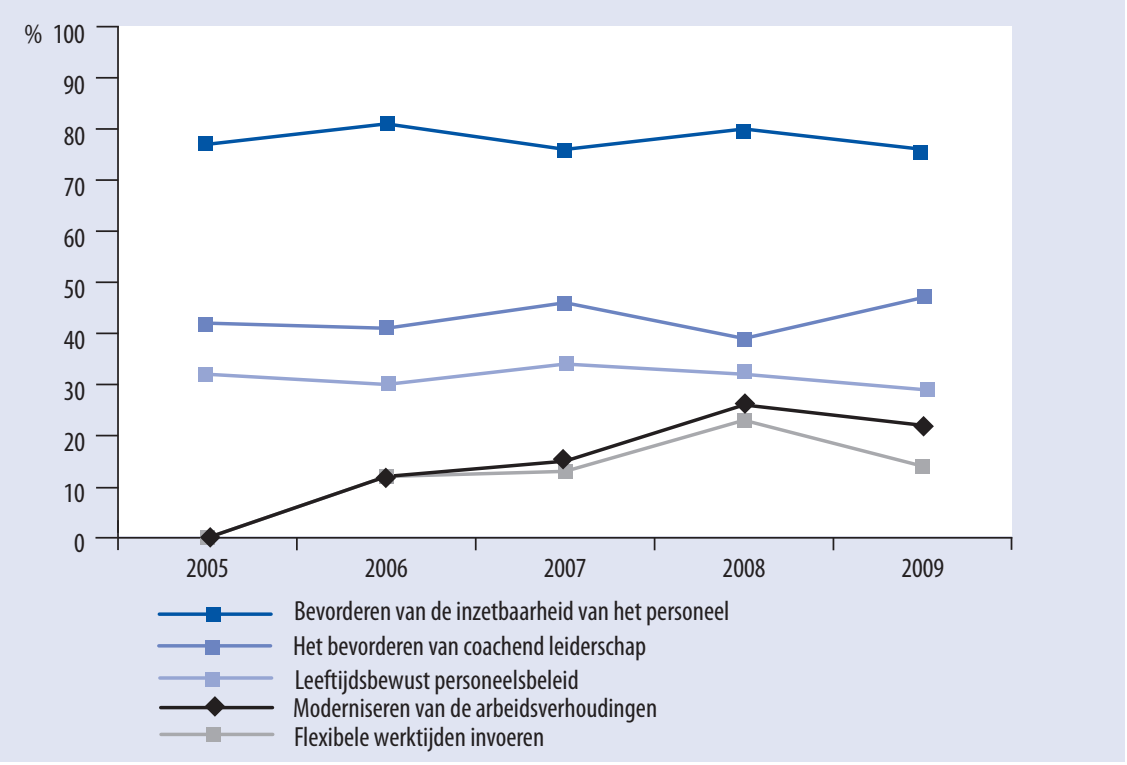

Bron: ROA/Werkgeverspanel Metalektro 2005-2009

Veel van de in de vorige paragrafen besproken organisatorische innovaties, zoals zelfsturende teams, leggen meer verantwoordelijkheden en beslissingsbevoegdheden bij de medewerkers. Het moderniseren van arbeidsverhoudingen in de organisatie sluit hier goed bij aan en het is daarom niet verwonderlijk dat ongeveer één van de vijf bedrijven dit als een speerpunt ziet voor hun toekomstige personeelsbeleid. Flexibele werktijden kunnen bijdragen aan het inzetten van personeel precies op die momenten dat het bedrijf hen het hardst nodig heeft. Tegelijkertijd bieden flexibele werktijden mogelijkheden om tegemoet te komen aan wensen van medewerkers in een bepaalde levensfase. Denk hierbij an het combineren van werk en zorg of werk en studie. Figuur 5.6 laat zien dat $\mathrm{I} 4 \%$ van de bedrijven de komende jaren flexibele werktijden willen invoeren, een flinke daling t.o.v. vorig jaar toen nog $23 \%$ van de bedrijven dit als speerpunt had. Het is goed mogelijk dat, o.a. door de recessie, veel bedrijven flexibele werktijden al hebben ingevoerd of er nu juist vanaf zien, bijvoorbeeld omdat andere zaken nu meer prioriteit hebben.

6. In plaats van leeftijd kan ook de levensfase bekeken worden waar iemand in zit, bijvoorbeeld het al of niet hebben van (kleine) kinderen. Levensfases zullen sterk samenhangen met leeftijd, maar dit hoeft niet altijd het geval te zijn. 


\section{Brede inzetbaarheid}

Het bevorderen van de inzetbaarheid van het personeel is al jaren lang het belangrijkste speerpunt voor het toekomstige HRM-beleid van de metalektrobedrijven (zie figuur 5.6). Deze inzetbaarheid kan betrekking hebben op de werktijd: hoeveel uren is men inzetbaar, op welke dagen en op welke tijden? Het vergroten van de inzetbaarheid is echter ook vaak gericht op het inzetbaar zijn voor meerdere taken, activiteiten of zelfs functies. Het gaat hier om het realiseren van een brede inzetbaarheid.

\section{Figuur 5.7}

Behoefte aan en daadwerkelijke brede inzetbaarheid van het personeel (\% bedrijven)

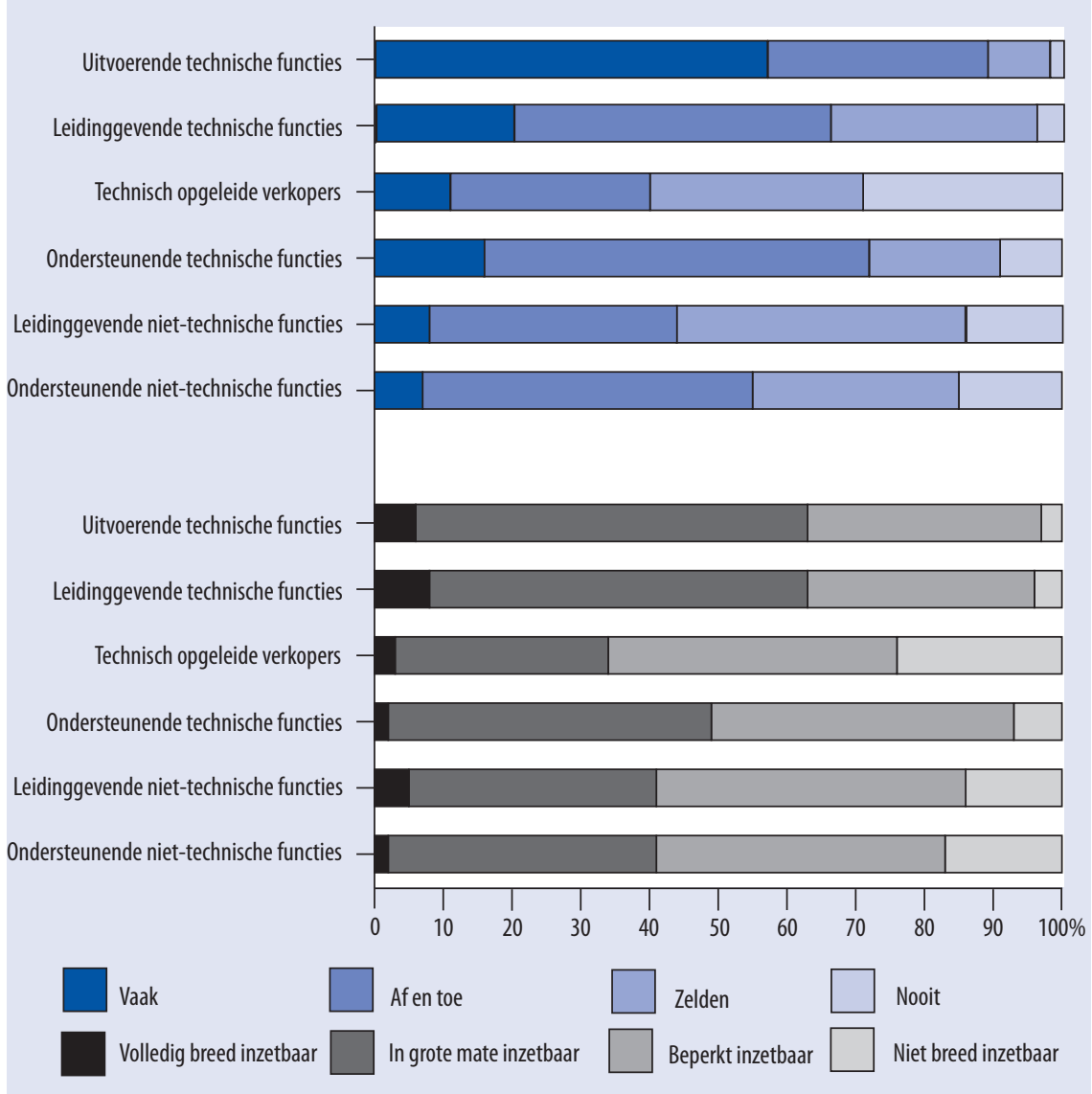

Bron: ROA / Werkgeverspanel Metalektro 2009

Figuur 5.7 geeft de verhouding weer tussen de behoefte van de metalektrobedrijven (bovenste helft) en de daadwerkelijke brede inzetbaarheid van hun personeel (onderste helft). Bij zowel de behoefte aan als de daadwerkelijke brede inzetbaarheid 
wordt gedifferentieerd naar functiegroep. De bedrijven in de Metalektro hebben de grootste behoefte aan een brede inzetbaarheid van hun uitvoerende technici: 57\% van de bedrijven geeft aan dat ze hier vaak behoefte aan hebben. Nog eens $32 \%$ van de bedrijven heeft af en toe behoefte aan breed inzetbare uitvoerende technici. Ook verwacht ongeveer de helft van de bedrijven af en toe een brede inzetbaarheid van haar leidinggevende en ondersteunende technici. Daarentegen is er weinig behoefte aan breed inzetbare technische verkopers: $61 \%$ van de bedrijven heeft hier zelden of nooit behoefte aan.

Sluit de inzetbaarheid van de werknemers in de Metalektro aan bij de grote behoefte aan breed inzetbare medewerkers? Bij de uitvoerende en leidinggevende technici lijkt deze aansluiting er deels te zijn: meer dan de helft van de bedrijven ( $57 \%$ en $55 \%$ ) vindt deze medewerkers in grote mate breed inzetbaar en een derde beperkt inzetbaar. De brede inzetbaarheid van technische verkopers is het laagst, maar aangezien de behoefte hieraan ook het laagst is, lijkt dit geen problemen op te leveren.

De hiervoor geschetste situatie in 2009 is grotendeels vergelijkbaar met die in 2008 . Metalektrobedrijven hebben in 2009 iets meer behoefte gekregen aan brede inzetbaarheid onder het personeel dat werkzaam is in de ondersteunende niet-technische functies. Daarnaast is de daadwerkelijke inzetbaarheid bij leidinggevende technici in 2009 iets afgenomen ten opzichte van 2008. In sommige bedrijven nam de brede inzetbaarheid van uitvoerende technici toe, in sommige nam deze af.

Waar komt de behoefte aan breed inzetbaar personeel vandaan? Deze vraag wordt in figuur 5.8 beantwoord voor het uitvoerend technisch personeel. Deze figuur laat de ontwikkeling van de vijf belangrijkste redenen van 2009 zien. $85 \%$ van de bedrijven heeft breed inzetbare uitvoerende technici nodig om de schommelingen in de bedrijvigheid op te vangen. Breed inzetbaar personeel zorgt dus voor de noodzakelijke conjuncturele flexibiliteit in het bedrijf, maar het vergroot ook de mogelijkheden om de continuïteit van het productieproces te garanderen als bepaalde medewerkers tijdelijk wegvallen. Immers, $45 \%$ van de bedrijven wil breed inzetbare technici om zieke werknemers te kunnen vervangen en $38 \%$ om werknemers die met verlof zijn te vervangen. Daarnaast leveren breed inzetbare uitvoerende technici volgens een derde van de bedrijven kostenbesparingen op. Tot slot is het breder inzetbaar maken van technici een uitstekende manier om hun functie aantrekkelijker te maken. Daarmee kan het vergroten van de inzetbaarheid van medewerkers ook fungeren als een bindmiddel. Dit mag gezien de conjuncturele situatie op dit moment een wat minder belangrijke reden lijken, maar veel bedrijven zijn zich blijkbaar goed bewust van dit effect van een brede inzetbaarheid inzetbaarheid van hun personeel en het belang hiervan als de conjunctuur weer aantrekt.

In figuur 5.8 is te zien dat bedrijven in 2009 vaker dan in 2008 aangeven dat een brede inzetbaarheid van hun technisch personeel nodig is voor het opvangen van werknemers die met verlof zijn ( $38 \%$ t.o.v. $27 \%$ ). Daarentegen geven de metalektrobedrijven 
in 2009 minder vaak aan behoefte te hebben aan een brede inzetbaarheid van hun personeel om tekorten aan bepaalde werknemers op te vangen (23\% t.o.v. 33\%) of omdat de werknemers zelf graag breed inzetbaar willen zijn (22\% t.o.v. $31 \%)$. Deze dalingen hangen waarschijnlijk samen met de economische crisis waardoor bedrijven minder personeelstekorten ervaren en werknemers baanzekerheid een hogere prioriteit geven dan de baaninhoud.

\section{Figuur 5.8}

Redenen voor behoefte aan breed inzetbare uitvoerende technici (\% bedrijven)

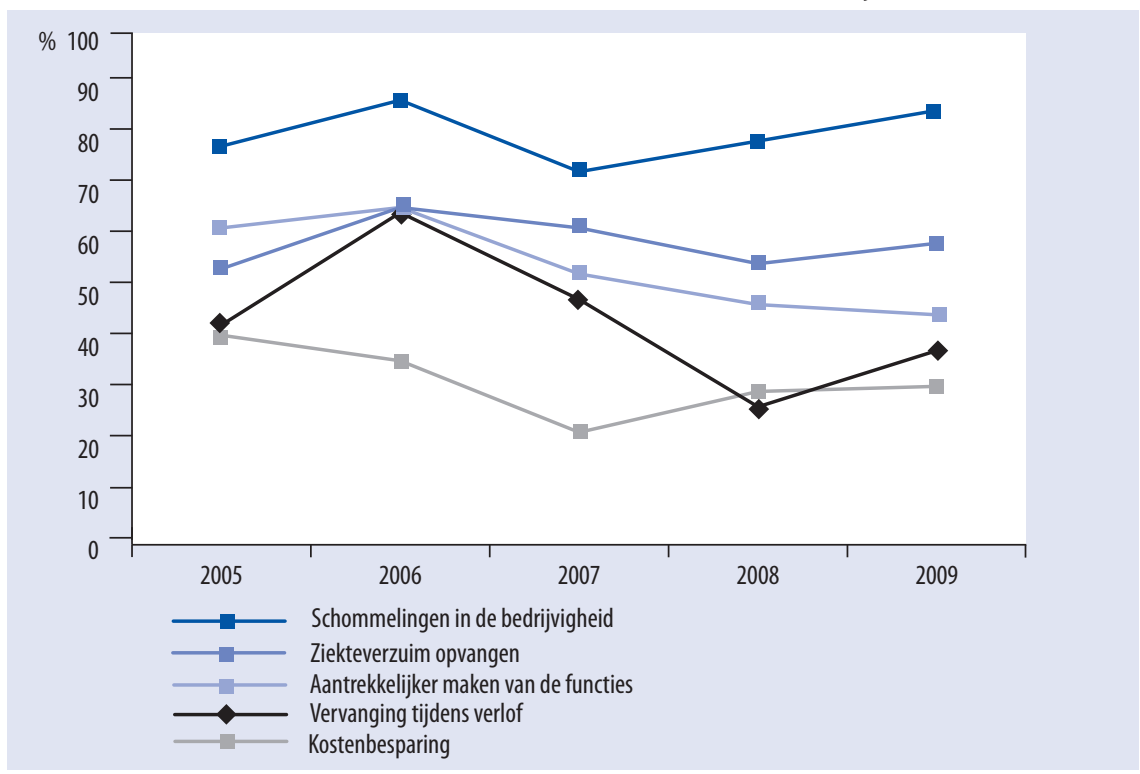

Bron: ROA / Werkgeverspanel Metalektro 2005-2009

\subsection{Externe samenwerking}

Sociale innovatie beperkt zich niet tot de interne organisatie en het ontwikkelen en benutten van het in de onderneming beschikbare menselijke kapitaal. Bedrijven ontlenen immers hun bestaansrecht uit wat zij voor hun omgeving kunnen betekenen. In deze bedrijfsomgeving bevinden zich de klanten, leveranciers, concurrenten, kennisinstellingen en overheden. Metalektrobedrijven onderhouden allerlei externe relaties die ruimte voor innovatie bieden. Innovaties in deze sfeer hebben vaak betrekking op het creëren of intensiveren van de samenwerking, of op het op een andere manier samenwerken dan voorheen. In de komende vijf jaar wil bijvoorbeeld $20 \%$ van de bedrijven intensiever samenwerken met andere bedrijven, terwijl $36 \%$ van de bedrijven de samenwerking met het onderwijsveld wil intensiveren. 
HOOFDSTUK 5

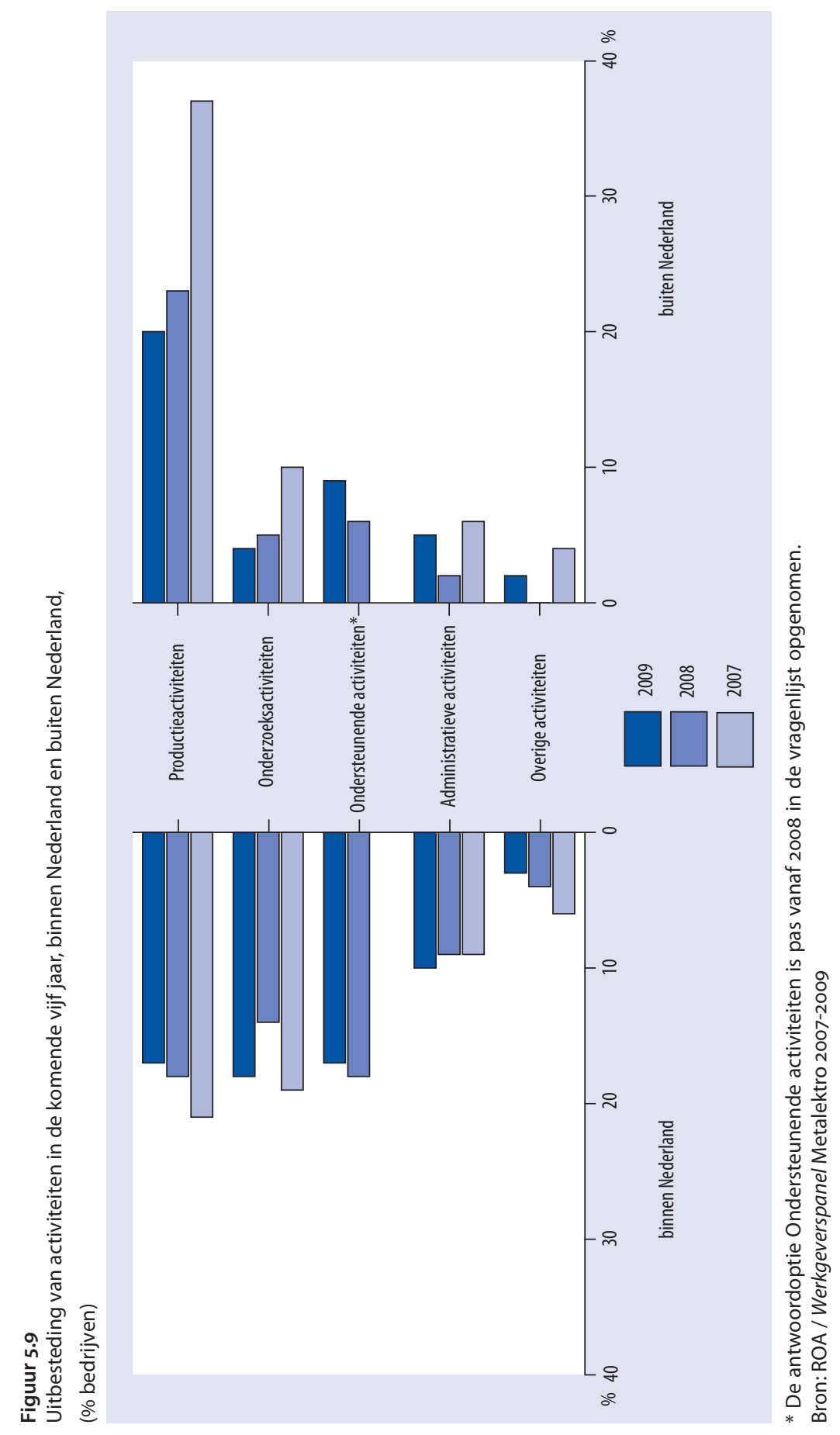


Het uitbesteden van werkzaamheden naar een ander bedrijf creëert vanzelfsprekend een nauwe samenwerkingsrelatie met dat bedrijf. Figuur 5.9 geeft een overzicht van de ontwikkeling van de geplande outsourcing activiteiten in de Metalektro. In de Arbeidsmarktmonitor is dit de afgelopen drie jaren gemeten aan de hand van de vraag "Zullen in de komende vijf jaren meer activiteiten uitbesteed worden dan in het afgelopen jaar?" Daarbij wordt er een onderscheid gemaakt tussen het uitbesteden van activiteiten aan een bedrijf binnen Nederland (linkerhelft van de grafiek) en het uitbesteden van activiteiten aan een bedrijf buiten Nederland (rechterhelft grafiek).

\begin{abstract}
Andere vormen van externe samenwerking
Diverse metalektrobedrijven werken nauw samen met hun klanten als het gaat om productontwikkeling. Het metalektrobedrijf is namelijk goed in staat om al in een vroeg ontwikkelstadium aan te geven wat de technische (on) mogelijkheden zijn en of de eisen die aan de keten worden gesteld bij het produceren van het te ontwikkelen product, uitvoerbaar zijn. Deze zaken dragen in hoge mate bij aan het welslagen van het nieuwe product. Een ander gebied waarop metalektrobedrijven soms samenwerken met hun klanten is voorraadbeheer. Door gebruik te maken van ICT houden metalektrobedrijven de voorraad bij hun klanten nauwlettend in de gaten en zorgen dat deze just-in-time wordt aangevuld. Dit levert aanzienlijke kostenbesparingen op.

Wanneer een bedrijf een (groot) deel van de componenten voor het eindproduct door anderen laat produceren, ontstaat een wederzijdse afhankelijkheid. $0 \mathrm{~m}$ dit in goede banen te leiden heeft één van de metalektrobedrijven met haar toeleveranciers vergaande afspraken gemaakt over 0.a. kwaliteit en logistiek. Daarnaast mogen toeleveranciers slechts voor een bepaald deel van hun omzet van dit bedrijf afhankelijk zijn en is er vrijwel altijd een tweede toeleverancier per component beschikbaar.
\end{abstract}

\title{
Binnen Nederland
}

Productieactiviteiten worden niet alleen buiten maar ook binnen Nederland uitbesteed: $17 \%$ van de metalektrobedrijven zal in de komende jaren meer van deze activiteiten door Nederlandse bedrijven laten uitvoeren (zie figuur 5.9). Voor onderzoek en ondersteunende activiteiten vinden we vergelijkbare percentages. Slechts één op de tien bedrijven verwacht een toename in de uitbesteding van administratieve activiteiten naar een ander bedrijf binnen de landsgrenzen. De afgelopen jaren is een licht dalende trend waarneembaar in de binnenlandse uitbesteding van productie, maar bij de overige activiteiten verandert het uitbestedingspatroon nauwelijks. Bij de outsourcing van werkzaamheden blijkt dat metalektrobedrijven de oplossing vaak dicht bij huis zoeken: met uitzondering van de productieactiviteiten besteden de bedrijven hun activiteiten vaker uit aan bedrijven binnen Nederland dan aan bedrijven buiten Nederland. 


\section{Buiten Nederland}

Productieactiviteiten staan in de Metalektro het vaakst op de nominatie om naar het buitenland te worden overgeheveld: $20 \%$ van de bedrijven verwacht in de komende vijf jaar meer productieactiviteiten aan een bedrijf buiten de landsgrenzen uit te gaan besteden (zie rechterhelft figuur 5.9). Eén op de elf bedrijven heeft uitbestedingplannen voor ondersteunende activiteiten. De plannen om onderzoeksactiviteiten, administratieve en overige activiteiten uit te gaan besteden zijn in 2009 niet of nauwelijks toegenomen ten opzichte van de plannen in 2008. In de afgelopen drie jaar is er bij productie- en onderzoeksactiviteiten sprake van een dalende trend in het uitbesteden van activiteiten naar het buitenland. Deze daling kan te maken hebben met het terughalen van eerder uitbestede activiteiten naar het eigen bedrijf, om daarmee de leegloop vanwege de daling van de afzet voor een deel op te kunnen vangen (zie figuur I.3). Ook kan er sprake zijn van een tegenvallend rendement van de eerdere outsourcing. Door de vraagstelling is het ook mogelijk de daling te verklaren doordat bedrijven die in de afgelopen jaren al veel hebben uitbesteed hebben, de komende jaren niet nog meer gaan uitbesteden. Overigens is er bij de ondersteunende activiteiten wel sprake van een lichte toename in de uitbesteding naar het buitenland. 


\section{Vergrijzing en active ageing beleid}

In dit hoofdstuk wordt ingegaan op de vergrijzing in de Metalektro en de gevolgen hiervan voor de bedrijven. We staan onder meer stil bij het percentage werknemers dat binnen vijf jaar met pensioen zal gaan, de door de metalektrobedrijven verwachte vervangingsproblemen en de maatregelen die de bedrijven nemen om deze vervangingproblemen tegen te gaan. Daarnaast wordt ingegaan op de vraag in hoeverre de metalektrobedrijven een active ageing beleid voeren en op welke manier dit beleid vormgegeven wordt.

\subsection{Uitstroom door vergrijzing en vervangingsproblemen}

Volgens de brede sectordefinitie van het CBS was in 2008 23\% van de werknemers in de Metalektro ouder dan 50 jaar. Bedrijven in de sectoren Basismetaal en Transportmiddelen hebben met $30 \%$ en $26 \%$ relatief de meeste oudere werknemers. Daarentegen hebben de bedrijven in de sector Metaalproducten en in de Machine-industrie met elk 22\% het laagste percentage oudere werknemers in dienst. Al deze cijfers zijn afkomstig van de Enquête Beroepsbevolking, die is gebaseerd op een onderzoek onder werknemers uit allerlei sectoren. De in hoofdstuk 2 gepresenteerde cijfers van het PME geven aan dat het percentage 50-plussers in 2009 nog hoger ligt. Volgens figuur 2.6 is zelf bijna een derde van alle werknemers die aangesloten zijn bij het PME ouder dan 50 jaar.7

In de figuren 6.Ia en 6.Ib wordt weergegeven hoeveel procent van de werknemers in de Metalektro de komende vijf jaar in de verschillende functiecategorieën met pensioen zal gaan. De figuren laten ook de ontwikkeling van deze verwachtingen in de afgelopen vijf jaar zien. In 2009 verwachten de metalektrobedrijven dat in de komende vijf jaar $7 \%$ van hun werknemers in de uitvoerende technische functies met pensioen zal gaan. Dit is minder dan in 2007 en 2008 , toen verwacht werd dat $9 \%$ van de werknemers in de uitvoerende technische functies binnen vijf jaar met pensioen zou gaan. $\mathrm{Nu}$ is dit aandeel weer terug op het niveau van 2005. Bij de leidinggevende

7. De cijfers van CBS en PME zijn door verschillende oorzaken helaas niet goed vergelijkbaar. De PME-cijfers zijn representatief voor alle bedrijven die aangesloten zijn bij het pensioensfonds. De werknemers van de bedrijven met een eigen $\mathrm{CAO}$ worden daarbij dus niet meegenomen. Het CBS trekt een steekproef onder alle werkenden in de Metalektro, waarbij het CBS de Metalektro overigens breder definieert dan het PME. 
technische functies is het percentage werknemers dat binnen vijf jaar met pensioen gaat in 2009 veel lager: de bedrijven verwachten gemiddeld genomen dat $3 \%$ van hun technische leidinggevenden in de komende vijf jaar zal afzwaaien.

\section{Figuur 6.1a}

Ontwikkeling percentage werknemers dat in de komende vijf jaar met pensioen gaat, per functiecategorie

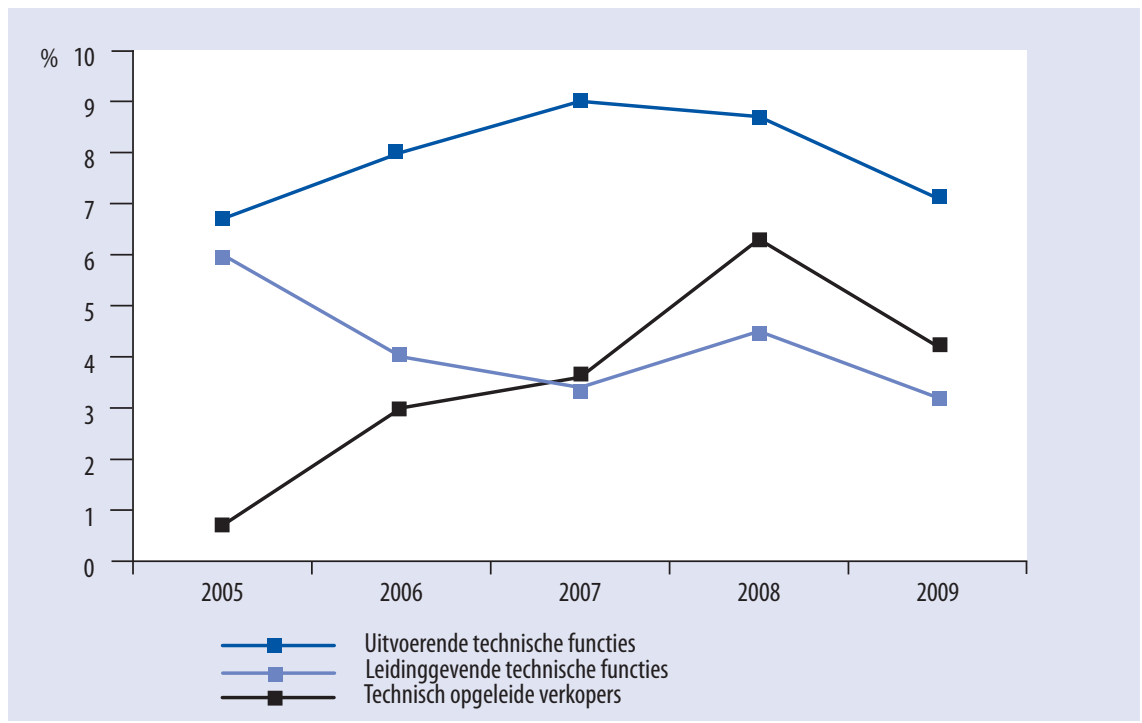

Bron: ROA / Werkgeverspanel Metalektro 2005-2009

Het verwachte percentage technisch leidinggevenden dat in de komende vijf jaar met pensioen gaat is sinds 2005 sterk teruggelopen. Zo werd in 2005 nog verwacht dat $6 \%$ van de technische leidinggevenden binnen vijf jaar met pensioen zou gaan. Bij de technisch opgeleide verkopers zien we een geheel ander patroon: in 2009 verwachten de bedrijven in de Metalektro dat $4 \%$ van hun technisch opgeleide verkopers binnen vijf jaar van hun pensioen zal gaan genieten, terwijl dit in 2005 nauwelijks $1 \%$ was. Tussen 2005 en 2008 steeg de verwachte uitstroom door pensionering in deze functiecategorie echter gestaag tot $6 \%$. Dit illustreert dat ook de werkenden in deze functie steeds vaker de pensioengerechtigde leeftijd bereiken. In 2009 is het percentage echter weer gedaald. De daling van de voor de komende jaren verwachte pensioenuitstroom in 2009 illustreert dat de bedrijven er vanuit gaan dat hun personeel de komende jaren later met pensioen zal gaan. Het effect van dit langer doorwerken is naar verwachting zelfs zo groot dat het de toename van de pensioenuitstroom vanwege de vergrijzing van het personeelsbestand meer dan compenseert. 


\section{Figuur $6.1 \mathrm{~b}$}

Ontwikkeling aandeel werknemers dat in de komende vijf jaar met pensioen gaat, per functiecategorie

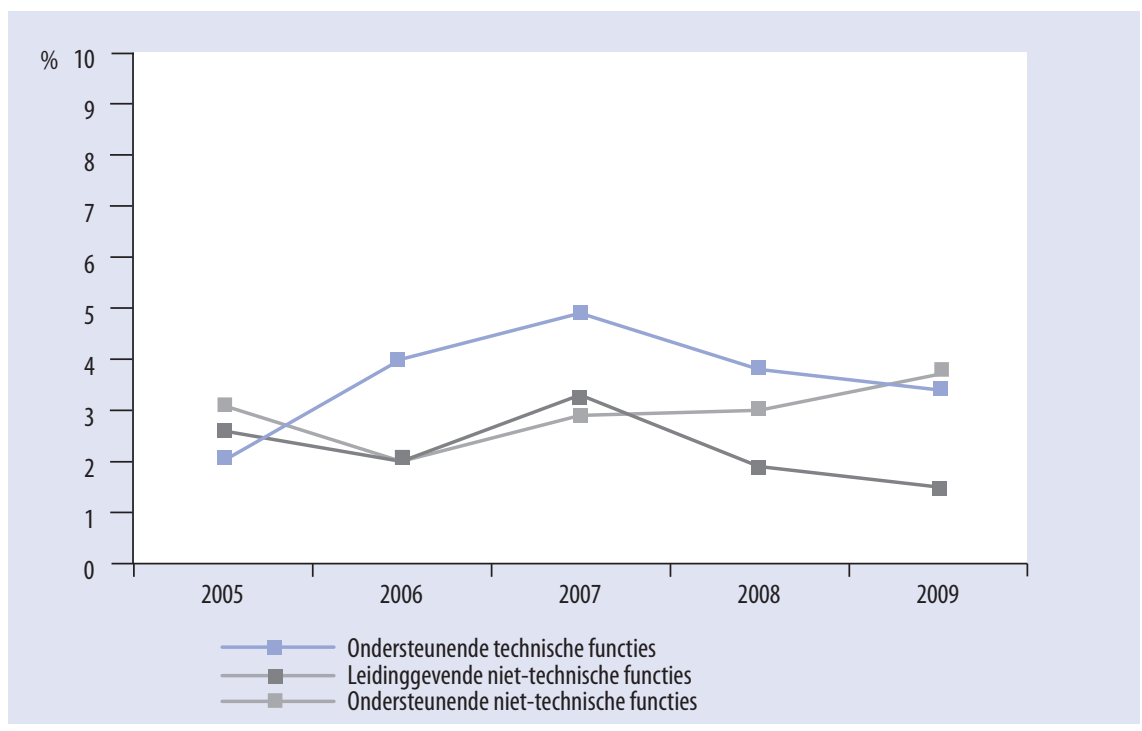

Bron: ROA / Werkgeverspanel Metalektro 2005-2009

De bedrijven verwachten in 2009 dat $3,5 \%$ van hun medewerkers die werkzaam zijn in de ondersteunende functies in de komende vijf jaar zal uitstromen omdat zij met pensioen gaan. In de ondersteunende technische functies was dit in 2005 nog slechts $2 \%$ van de werkenden, waarna de verwachte uitstroom in 2007 opliep tot $5 \%$. In de afgelopen twee jaar is dit percentage echter weer teruggelopen. Voor de leidinggevende niet-technische functies verwachten de bedrijven in 2009 dat slechts een zeer laag percentage van de medewerkers die werkzaam zijn in deze functies binnen vijf jaar met pensioen zullen gaan, namelijk I,5\%. Dit percentage was in 2007 nog twee keer zo groot. Voor de ondersteunende niet-technische functies verwachten de bedrijven in 2009 dat bijna $4 \%$ van hun werknemers binnen vijf jaar met pensioen gaat. Dit is het hoogste percentage van de afgelopen vijf metingen, al zijn de verschillen tussen de jaren voor deze functies relatief klein. Deze functiecategorie is daarmee de enige waarvoor verwacht wordt dat het percentage werkenden dat de komende jaren met pensioen gaat zal toenemen. Dit betekent dat het langer doorwerken het vergrijzingseffect in deze functiecategorie niet weet op te vangen.

In figuur 6.2 wordt het percentage bedrijven weergegeven dat verwacht problemen te zullen ondervinden bij de vervanging van werknemers die in de komende vijf jaar met pensioen gaan. De meeste vervangingsproblemen worden er verwacht voor de uitvoerende technici: $65 \%$ van de bedrijven in de Metalektro verwacht veel vervangingsproblemen voor deze functies. Daarbij verwacht $23 \%$ van de bedrijven zelfs veel problemen. $53 \%$ van de bedrijven verwacht vervangingsproblemen voor de leidingge- 
vende technische functies; $22 \%$ van de bedrijven verwacht voor deze functiecategorie zelfs veel problemen. Voor de technisch opgeleide verkopers verwacht $42 \%$ van de bedrijven vervangingsproblemen en $2 \mathrm{I} \%$ zelfs veel vervangingsproblemen. De minste vervangingsproblemen worden er verwacht voor de ondersteunende technische functies, al verwacht ook hier nog $47 \%$ van de bedrijven op z'n minst enige problemen. Het aantal bedrijven dat voor deze functiecategorie veel vervangingsproblemen verwacht is echter klein (9\%).

\section{Figuur 6.2}

Verwachte problemen bij het vervangen van werknemers die in de komende vijf jaar met pensioen zullen gaan, per functiecategorie

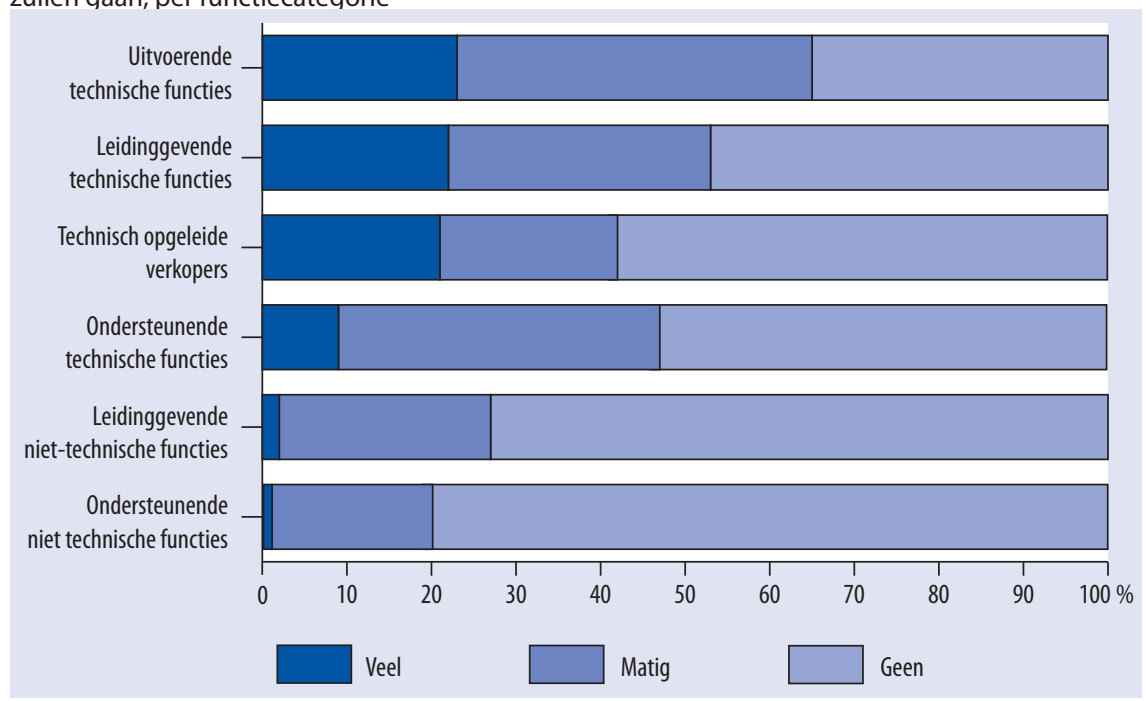

Bron: ROA / Werkgeverspanel Metalektro 2009

Overigens verwacht bijna geen enkel bedrijf grote vervangingsproblemen voor de niet-technische functies. Slechts $2 \%$ van de bedrijven verwacht veel vervangingsproblemen voor de leidinggevende functies, terwijl slechts I\% van de bedrijven verwacht dat het moeilijk wordt om de komende jaren in de ondersteunende functies het personeel dat met pensioen gaat te vervangen. Ook het percentage bedrijven dat voor deze functiegroepen matige vervangingsproblemen verwacht, is nog steeds laag: een kwart van de bedrijven in de leidinggevende functies en één op de vijf bedrijven in de ondersteunende functies. Met andere woorden: voor de leidinggevende en ondersteunende niet-technische functies verwacht respectievelijk $73 \%$ en $81 \%$ van de bedrijven geen problemen bij de vervanging van werknemers die in de komende vijf jaar met pensioen gaan.

Figuur 6.3 wekt sterk de indruk dat de economische crisis zich ook bij de vervangingsproblemen van gepensioneerde werknemers laat gelden: de cijfers voor 2009 wijken sterk af van die in de voorgaande jaren. Sinds 2006 verwachtte nog $70 \%$ tot $80 \%$ 
van de bedrijven problemen bij de vervanging van personeel dat met pensioen zou gaan. In 2008 was dit percentage voor de technisch opgeleide verkopers, leidinggevende technische functies en ondersteunende functies zelfs opgelopen tot ongeveer 90\% van de bedrijven. ${ }^{8}$ Hoe anders is het beeld in 2009: afhankelijk van de functiegroep verwachten nu slechts $42 \%$ tot $65 \%$ van de bedrijven problemen om technici die met pensioen gaan te vervangen. Naast het effect van de afnemende schaarste op de arbeidsmarkt vanwege de economische crisis nemen de verwachte vervangingsproblemen waarschijnlijk ook af, omdat de bedrijven er vanuit gaan dat het oudere personeel dat bij hen in dienst is iets langer blijft doorwerken (zie figuren 6.Ia en 6.Ib).

\section{Figuur 6.3}

Ontwikkeling verwachte problemen bij het vervangen van werknemers die in de komende vijf jaar met pensioen zullen gaan, matige of veel problemen, technisch personeel

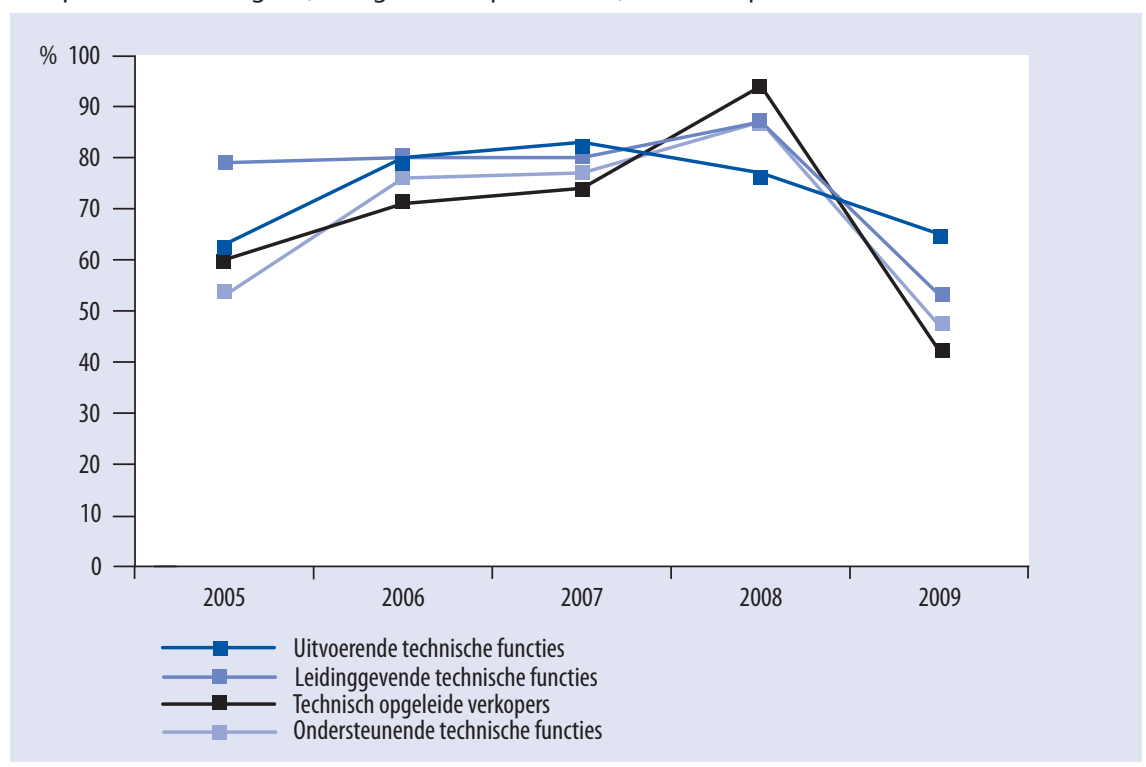

Bron: ROA / Werkgeverspanel Metalektro 2005-2009

Het is echter de vraag of metalektrobedrijven niet te vroeg juichen. Wellicht is hun inschatting van afnemende vervangingsproblemen in de komende vijf jaar bovenmatig beïnvloed door de crisis en is het crisiseffect al veel eerder uitgewerkt dan men nu denkt. Deze indruk over het werken met een korte tijdshorizon als het om personeelsplanning gaat, wordt bevestigd door de reacties op de Quickscanstelling "Onze personeelsplanning gaat over een langere tijdshorizon": $57 \%$ van de bedrijven is het (helemaal) niet eens met deze stelling.

8. De vragen waar dit hoofdstuk op gebaseerd is, worden ieder jaar in de maand juli aan de bedrijven voorgelegd. De cijfers van 2008 zijn dus nog niet beïnvloed door de economische crisis. 


\subsection{Aanpak vervangingsproblemen door vergrijzing}

Welke maatregelen nemen de metalektrobedrijven om de verwachte problemen bij de vervanging van hun technisch personeel dat met pensioen gaat het hoofd te bieden? Figuur 6.4 laat zien dat de meeste bedrijven zich in 2009 richten op vijf maatregelen: het huidige personeel om- of bijscholen (71\%), relaties met het onderwijsveld intensiveren $(69 \%)$, de werknemers breder inzetbaar maken door taakroulatie (69\%), de aantrekkelijkheid van het bedrijf als werkgever vergroten (68\%) en nieuwe werknemers aannemen en zelf opleiden (66\%). Daarnaast proberen veel bedrijven toekomstige vervangingsproblemen op te vangen door het aannemen van nieuwe, goed opgeleide werknemers (59\%), gebruik te maken van arbeidsbesparende technologie $(58 \%)$ en het stimuleren van de carrièreplanning van werknemers $(58 \%)$. Opvallend genoeg vangt minder dan de helft van de bedrijven vervangingsproblemen op door het aannemen van schoolverlaters.

Als we kijken naar de maatregelen die de bedrijven de komende vijf jaar willen invoeren om vervangingsproblemen op te vangen, dan zien we dat met name de momenteel reeds veel toegepaste maatregelen ook door andere bedrijven zullen worden overgenomen. Van de vijf momenteel meest toegepaste maatregelen zullen de volgende maatregelen in de toekomst ook door andere bedrijven worden nagevolgd: schoolverlaters aannemen (20\%), nieuwe, goed opgeleide werknemers aannemen ( $19 \%)$ en de carrièreplanning van de werknemers stimuleren ( $16 \%)$.

\section{Figuur 6.4}

HR maatregelen om toekomstige vervangingsproblemen te beperken (\% bedrijven)

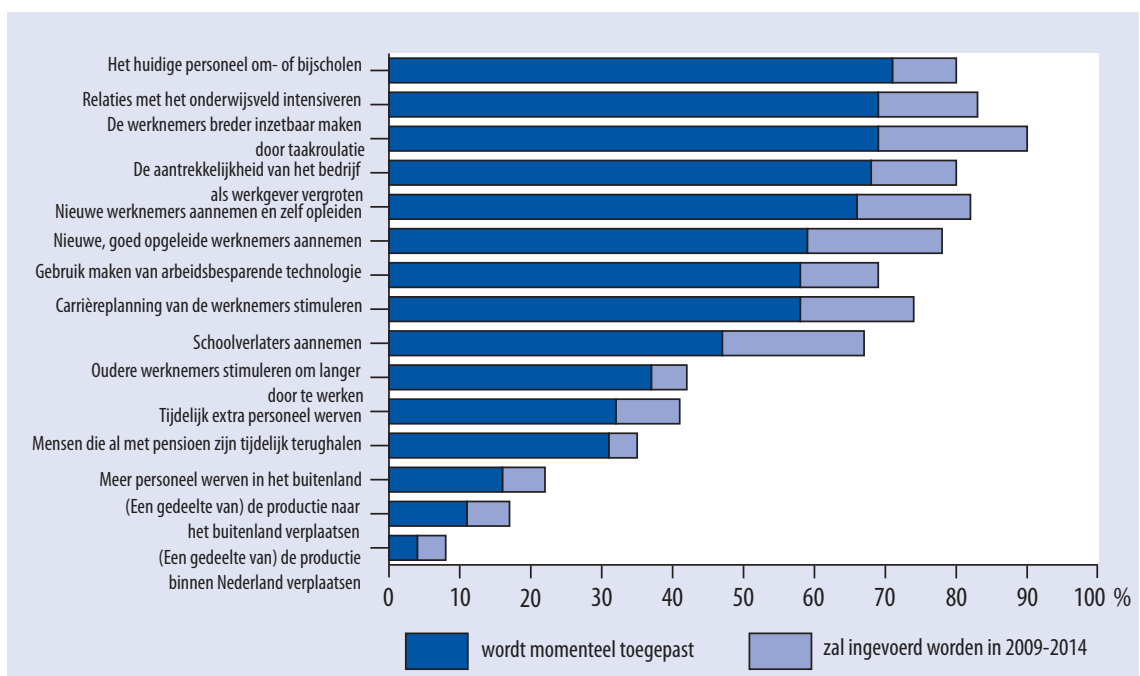

Bron: ROA / Werkgeverspanel Metalektro 2009 
Figuur 6.5 laat zien hoe een drietal maatregelen ter beperking van vervangingsproblemen zich de afgelopen jaren onder de metalektrobedrijven sterk heeft verspreid. Het nemen van maatregelen gericht op het vergroten van de aantrekkelijkheid van het bedrijf als werkgever is in de afgelopen vijf jaar steeds populairder geworden. In 2005 en 2006 probeerde nog slechts $23 \%$ van de bedrijven om langs deze weg hun vervangingsproblemen te verminderen, maar in 2007 was dit al bij de helft van de bedrijven het geval en in 2009 zelfs bij ruim tweederde van de metalektrobedrijven. Het stimuleren van de loopbaanplanning van de werknemers maakte een soortgelijke ontwikkeling door. In 2006 probeerde slechts I6\% van de bedrijven op deze manier hun vervangingsproblematiek op te vangen. In 2007 verdubbelde dit percentage en in 2009 gaf zelfs $58 \%$ van de bedrijven aan dat ze door een goede loopbaanplanning toekomstige vervangingsproblemen proberen op te vangen. Ook was er een sterke stijging van het percentage bedrijven dat vervangingsproblemen probeert op te vangen door de relaties met het onderwijsveld intensiveren. Dit percentage steeg van $25 \%$ van de bedrijven in 2006 naar $69 \%$ van de bedrijven in 2009. Eveneens was er een sterke toename van het percentage bedrijven dat hun personeel om- of bijschoolt (van $38 \%$ in 2006 tot $71 \%$ in 2009). ${ }^{9}$ De toenemende populariteit van deze vier HR-maatregelen laat zien dat steeds meer bedrijven er oog voor hebben gekregen dat ze hun vervangingsproblemen pro-actief moeten oplossen in plaats van het zoeken naar ad hoc oplossingen op het moment dat ze met concrete vervangingsproblemen worden geconfronteerd.

\section{Figuur 6.5}

Ontwikkeling van enkele maatregelen om vervangingsproblemen te beperken

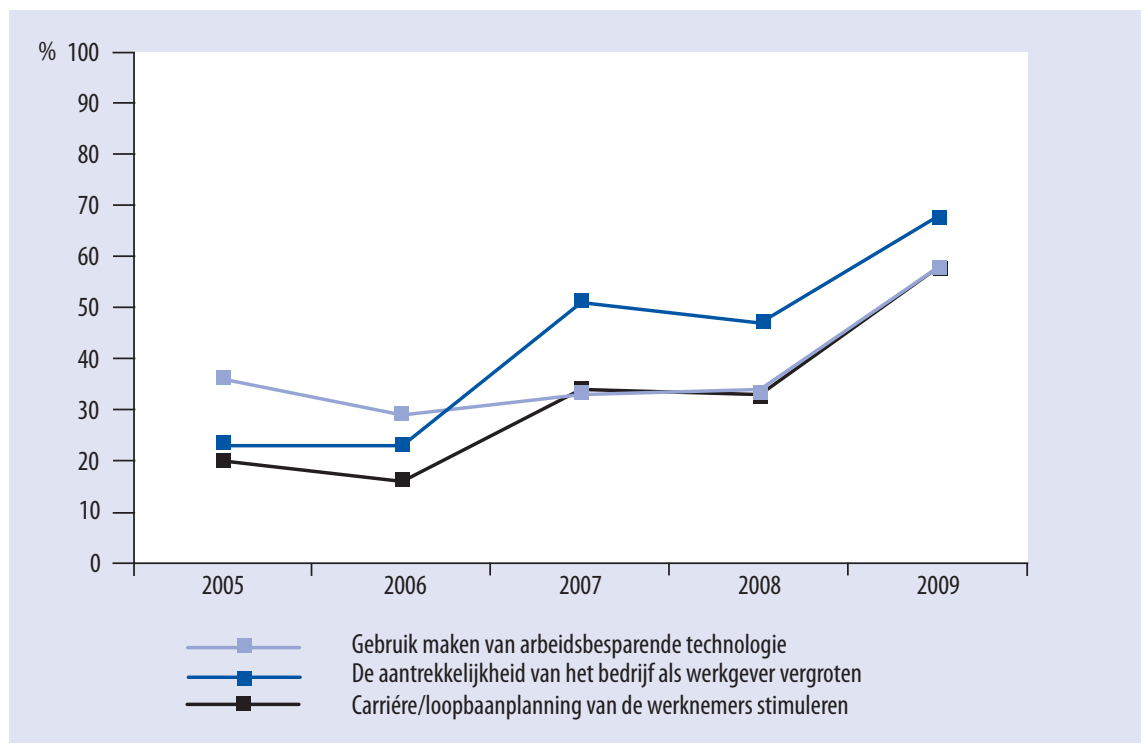

Bron: ROA / Werkgeverspanel Metalektro 2005-2009

9. Dit komt ten dele voort uit de scholingsverplichting van de $w$ tv/deeltijd-WW regeling. 
Eveneens was er in 2009 een sterke stijging van het aantal bedrijven dat vervangingsproblemen probeert op te vangen door gebruik te maken van arbeidsbesparende technologie. Nadat in de jaren 2005-2008 ongeveer een derde van de bedrijven langs deze weg vervangingsproblemen probeerde op te vangen, steeg dit in 2009 tot $58 \%$ van de metalektrobedrijven. Daarentegen was er een daling van het percentage bedrijven dat vervangingsproblemen wil opvangen door het aantrekken van nieuwe werknemers die men vervolgens zelf opleidt (van $83 \%$ in 2008 naar $66 \%$ in 2009).

\section{Werknemers opleiden met behulp van een eigen bbl-traject}

Eén van de metalektrobedrijven heeft binnen de eigen muren een bbl-2 opleidingstraject opgezet in samenwerking met een ROC. Het bedrijf beoogt met deze drastische investering het werkniveau van het personeel dusdanig te verhogen dat het weer aansluit bij de complexer geworden werkzaamheden. Een ander doel van het traject is het aanleren van eenzelfde manier van werken wat de kwaliteit en de efficiency van de output ten goede moet komen. Bovendien stelt dit bbl-traject de werknemers in staat om kwalificaties te halen die ook buiten het bedrijf erkend worden en laat het bedrijf zo aan haar klanten laten zien dat de kwaliteit van het geleverde product wordt gewaarborgd door opleiding van de medewerkers. Een neveneffect van dit traject is dat het bedrijf een beeld krijgt van de algemene ontwikkel/leercapaciteiten van de deelnemende werknemers.

\subsection{Active ageing}

Vervangingsproblemen hoeven niet alleen aangepakt te worden door het aantrekken van nieuw personeel. De vervangingsproblemen kunnen ook worden voorkomen door oudere werknemers te stimuleren om langer door te blijven werken, of door gepensioneerd personeel tijdelijk terug te halen. Respectievelijk $37 \%$ en $31 \%$ van de bedrijven gaf aan dit al te doen (zie figuur 6.4), nog eens $5 \%$ en $4 \%$ van de bedrijven wil dit in de komende vijf jaar gaan doen. Wanneer bedrijven oudere werknemers langer voor het bedrijf willen behouden, zullen ze daar in hun personeelsbeleid goed op moeten inspelen door het voeren van een active ageing beleid. In figuur 6.6 wordt een overzicht gegeven van de HR-instrumenten die de metalektrobedrijven momenteel in het kader van een dergelijk active ageing beleid inzetten.

Het blijkt dat de helft van de bedrijven in de Metalektro geen enkel active ageing instrument inzet. Bedrijven die in hun personeelsbeleid wel active ageing instrumenten inzetten, hanteren vooral de volgende HR-instrumenten: $35 \%$ van de bedrijven gebruikt oudere werknemers om kennis aan jongere medewerkers door te geven, terwijl $25 \%$ van de bedrijven de 45 -plussers in hun bedrijf mogelijkheden biedt om gedeeltelijk ander werk te gaan doen. Daarnaast geeft 22\% van de bedrijven aan dat ze de oudere werknemers in het bedrijf enigszins proberen te ontlasten door middel van taakroulatie. Andere active ageing instrumenten worden slechts door een beperkt aantal bedrijven ingezet om hun oudere medewerkers langer inzetbaar te houden. Daarbij gaat het om: loopbaangesprekken (I4\%), het aanbieden van extra 
opleidingsmogelijkheden ( $\mathrm{I} 3 \%)$, mogelijkheden om op andere tijden te werken (8\%) en het anders organiseren van de ploegendiensten (6\%).

\section{Figuur 6.6}

Active ageing instrumenten die ingezet worden voor het technisch personeel van 45 jaar en ouder

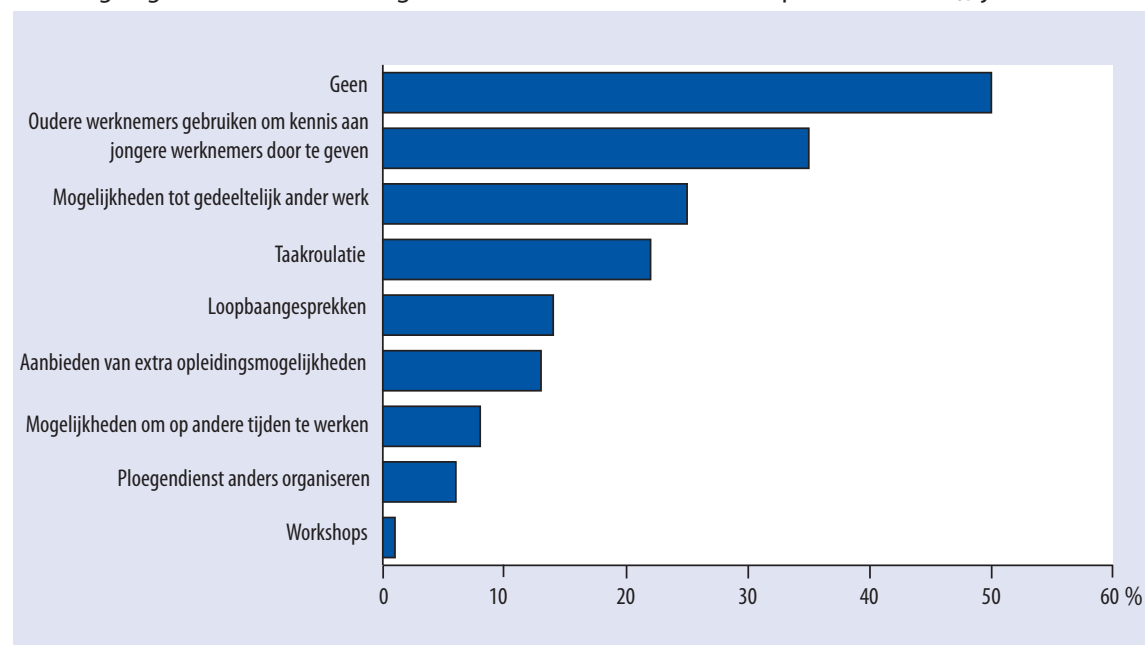

Bron: ROA / Werkgeverspanel Metalektro 2009

\section{De oudere werknemer als vak- én gedragscoach}

Metalektrobedrijven hebben niet zelden gelijktijdig te maken met de volgende twee uitdagingen: enerzijds een groep oudere medewerkers die niet goed benut wordt en anderzijds van het ROC instromende jongeren die intensief begeleid moeten worden vooraleer ze optimaal inzetbaar zijn op de werkvloer. Eén van de geïnterviewde bedrijven heeft beide uitdagingen in één keer aangepakt door een rigoureuze wijziging van de tot dan toe gebruikte opleidingsvorm.

In de nieuwe opleidingsvorm lopen ROC-leerlingen met de mentormonteur, een oudere ervaren monteur, mee op de werkvloer om het vak te leren. Op deze manier leert de leerling direct van de monteur zowel op vakinhoudelijk gebied, maar vooral ook op gebieden als veiligheid, werkhouding, e.d. Op zijn beurt stelt de leerling vragen aan de mentormonteur waardoor deze weer dingen gaat uitzoeken en gestimuleerd wordt om zijn eigen kennis up-to-date te houden. 0 ok leren de mentormonteurs van de contacten met de ROC-docenten en vice versa. De oudere werknemer wordt zo in zijn rol van mentormonteur weer belangrijk voor het bedrijf.

Als we de ontwikkeling van de inzet van deze instrumenten in de afgelopen jaren bekijken, dan valt op dat de meeste active ageing instrumenten door steeds minder bedrijven worden ingezet. Zo besteedde in 2008 nog slechts $13 \%$ van de bedrijven geen speciale aandacht aan oudere werknemers. In 2005 gebruikte nog $72 \%$ van de bedrijven oudere werknemers om kennis aan jongere werknemers door te geven. In de daaropvolgende jaren nam dit gestaag af tot 35\% van de bedrijven in 2009. In 2006 bestonden er nog in $71 \%$ van de bedrijven mogelijkheden tot gedeeltelijk ander werk. In 2009 was dit nog slechts bij respectievelijk 25\% van de bedrijven het geval. Ook 
had $7 \mathrm{I} \%$ van de bedrijven nog loopbaangesprekken voor hun oudere medewerkers, tegenover slechts $14 \%$ van de bedrijven in 2009. Ook de inzet van de andere active ageing instrumenten bereikte in 2009 een dieptepunt. Dit zal ongetwijfeld te maken hebben met de economische crisis. Door de sterk teruggelopen werkgelegenheid zullen sommige bedrijven eerder geneigd zijn hun oudere werknemers te stimuleren om met pensioen te gaan, dan om hen te stimuleren om langer door te werken. Als overlevingsstrategie voor de korte termijn is een dergelijke reactie zeer begrijpelijk. Op de lange termijn is dit echter een zorgwekkende ontwikkeling, gezien de toenemende noodzaak om de vervroegde pensionering af te gaan remmen. 


\section{De Metalektro in de toekomst}

In dit hoofdstuk wordt vooruit gekeken naar de ontwikkelingen in de bedrijfstak zoals die door de bedrijven in de Metalektro verwacht worden. De eerste paragraaf gaat over de arbeidsmarktontwikkelingen in de Metalektro. Daarna wordt in paragraaf 7.2 ingegaan op de verwachte veranderingen in de problematiek rond het vinden van voldoende geschikt personeel op de middellange termijn. Paragraaf 7.3 beschrijft de verwachte veranderingen in de functies van het technisch personeel, waarna paragraaf 7.4 afsluit met de verwachte ontwikkelingen op HRM-gebied.

\subsection{Arbeidsmarktontwikkeling in de Metalektro op de korte termijn: 2010-2011}

De metalektrobedrijven verwachten dat de aanhoudende upgrading van het vereiste opleidingsniveau voor het werken in de bedrijfstak zich de komende twee jaar zal voortzetten. In Figuur 7.I is te zien dat begin 2010 de helft van de bedrijven ervan uitgaat dat de werkgelegenheid voor LBO'ers in 2010 en 2011 weer verder zal afnemen. Daarentegen ziet slechts $5 \%$ van de bedrijven een afname van de werkgelegenheid op MBO-niveau, terwijl nagenoeg geen enkel bedrijf een daling van de werkgelegenheid voor HBO'ers en WO'ers verwacht. Dit betekent dat de bedrijven verwachten dat zeker voor de middelbaar en hoger opgeleide werknemers de bodem van de crisis, in termen van werkgelegenheid, reeds achter ons ligt. Er zijn zelfs behoorlijk wat bedrijven die voor 2010 en 2011 een toename van de werkgelegenheid voor HBO'ers en WO'ers verwachten. Op MBO-niveau verwacht 38\% van de bedrijven weer een toename van de werkgelegenheid, terwijl $23 \%$ van de bedrijven denkt dat in hun bedrijf de werkgelenheid voor hoog opgeleide werknemers zal toenemen.

Figuur 7.2 laat zien dat het totaal van de verwachte werkgelegenheidsgroei en -krimp voor de verschillende opleidingsniveaus nagenoeg in balans is. De verwachte groeien krimpcijfers bevestigen het beeld van een heroriëntering van laag- naar hoogopgeleid werk. De metalektrobedrijven verwachten een afname in de werkgelegenheid op LBO-niveau van 2.370 werknemers. Dit is iets minder dan de werkgelegenheidskrimp voor laag opgeleiden die begin 2009 werd verwacht (2.650 werknemers), maar duidelijk meer dan de krimpverwachtingen voor laag opgeleiden van begin 2008 . De afname van de werkgelegenheid op MBO-niveau is met 50 werknemers miniem, terwijl geen enkel bedrijf een afname van de werkgelegenheid op HBO/WO-niveau verwacht. 


\section{Figuur 7.1}

Verwachte werkgelegenheidsontwikkeling naar opleidingsniveau in 2010-2011 (\% bedrijven)

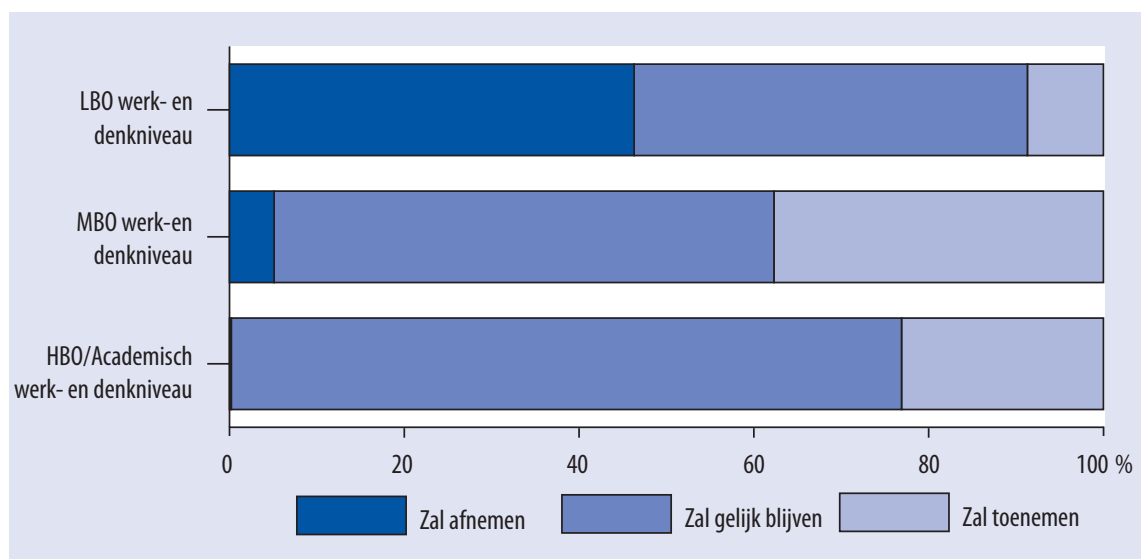

Bron: ROA / Werkgeverspanel Metalektro 2009

\section{Figuur 7.2}

Verwachte werkgelegenheidsontwikkeling naar opleidingsniveau 2010-2011 (aantallen werknemers)

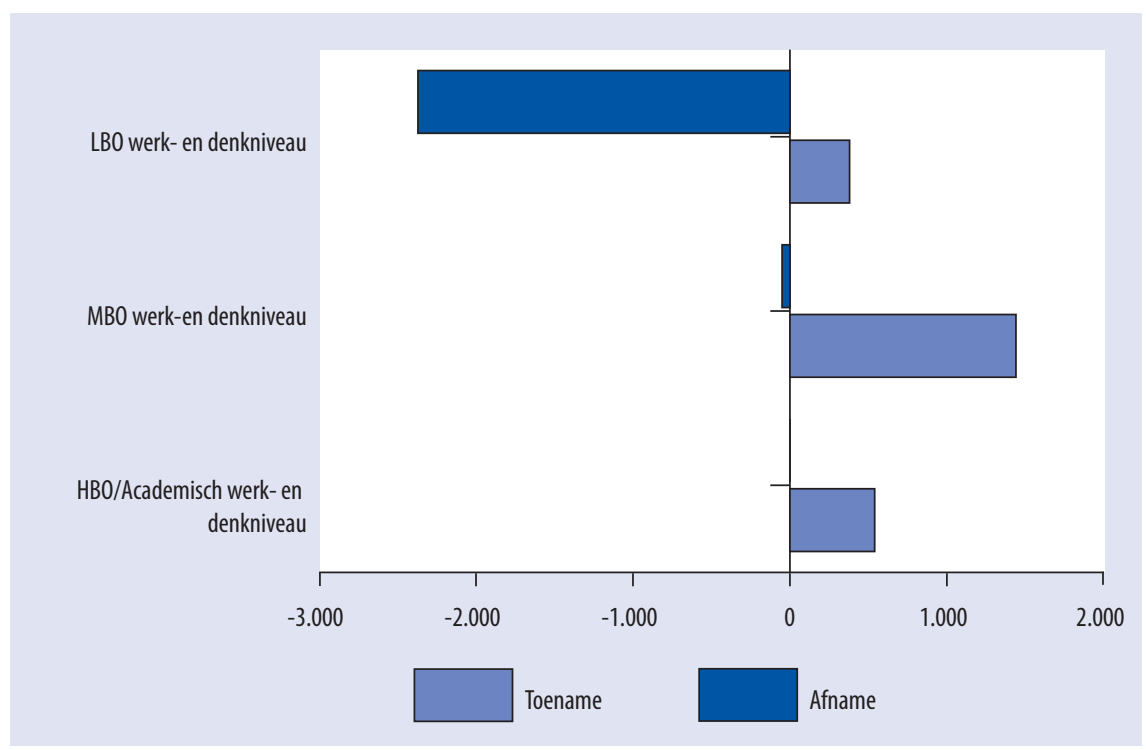

Bron: ROA / Werkgeverspanel Metalektro 2009

De metalektrobedrijven waar de werkgelegenheid op MBO-niveau toeneemt verwachten in totaal een toename van het aantal werknemers met een MBO-niveau met I.390 personen. Deze verwachting is duidelijk lager dan de werkgelegenheidsgroei op MBO-niveau die de bedrijven begin 2009 verwachtten (2.270 personen). 
Toen hoopten de bedrijven waarschijnlijk dat de crisis van korte duur zou zijn en de vraag naar de - qua omvang - belangrijkste groep van werknemers op $\mathrm{MBO}$-werken denkniveau weer snel zou gaan aantrekken. Nu verwachten de bedrijven in zowel 2010 als 2OII slechts een voorzichtig herstel van de werkgelegenheid op MBO-niveau. Vergelijkbaar is het beeld voor de werkgelegenheidgroei op HBO/WO werk- en denkniveau. De verwachte toename met 540 personen is duidelijk lager dan de meer optimistische inschattingen uit de voorgaande jaren. Zowel begin 2008 als begin 2009 verwachtten de bedrijven nog hun hoog opgeleide werknemersbestand met ruim I.000 personen uit te kunnen breiden.

\subsection{Ontwikkelingen op de middellange termijn: 2010-2014}

Ondanks de crisis houden veel bedrijven de vrees voor toekomstige tekorten aan vakkrachten bij het weer aantrekken van de economie in hun achterhoofd. Ook al lijkt het nu in de crisis nog moeilijk voorstelbaar, maar voor 2014 zullen er in verschillende segmenten van de arbeidsmarkt weer tekorten zijn. Volgens de arbeidsmarktprognoses van het Researchcentrum voor Onderwijs en Arbeidsmarkt (ROA) zijn er voor verschillende technische functies in 2014 weer grote knelpunten bij het invullen van vacatures. Er zullen dan weer problemen optreden bij het aantrekken van werknemers met een technische MBO-opleiding, zo is de voorspelling, omdat de arbeidsmarktinstroom vanuit deze opleidingen lager is dan de behoefte aan werknemers die vervangen moeten worden. ${ }^{\text {Io }}$ In de jaren voor de huidige economische crisis was het vaak ook erg moeilijk om bepaalde vakmensen aan te trekken. Vooral in de maakindustrie is de arbeidsmarktsituatie door de crisis echter abrupt omgeslagen. Naar verwachting zal de markt op dit segment de komende jaren echter weer omslaan omdat de uitstroom van ouderen groter is dan de instroom van schoolverlaters.

\section{"De Metalektro komt naar je toe deze zomer!"}

Voor de toekomst vindt $60 \%$ van de bedrijven dat ze gezamenlijk moeten investeren in de instroom van jonge vakkrachten, zo blijkt uit één van de Quickscans. Een aantal geïnterviewde bedrijven geeft vervolgens aan dat in dit verband goede contacten met scholen essentieel zijn. Zij hebben goede ervaringen met het naar de scholen toegaan door er gastlessen te verzorgen en met het geven van rondleidingen aan scholieren in het eigen bedrijf. Dit doen zij enerzijds om jongeren te laten zien wat voor soort werk er allemaal mogelijk is in de techniek en anderzijds om naamsbekendheid te krijgen bij de jongeren in de eigen regio. Onbekend maakt immers onbemind.

De meeste bedrijven zien de geringe instroom vanuit de opleidingen als een groot proleem. Meer dan 60\% van de bedrijven noemt dit probleem als hen wordt gevraagd naar de verwachte problemen bij het vinden van technici in de komende vijf jaar (zie

IO. Zie ROA (2009): De arbeidsmarkt naar opleiding en beroep tot 2014, ROA-R-2009/5, hoofdstukken 2 en 3 . 
figuur 7.3). Zoals figuur 7.3 laat zien, verschilt dit overigens niet van de verwachtingen die de bedrijven de voorgaande jaren hadden.

Figuur 7.3

Verwachte problemen bij het vinden van technisch personeel in de komende vijf jaar (\% bedrijven)

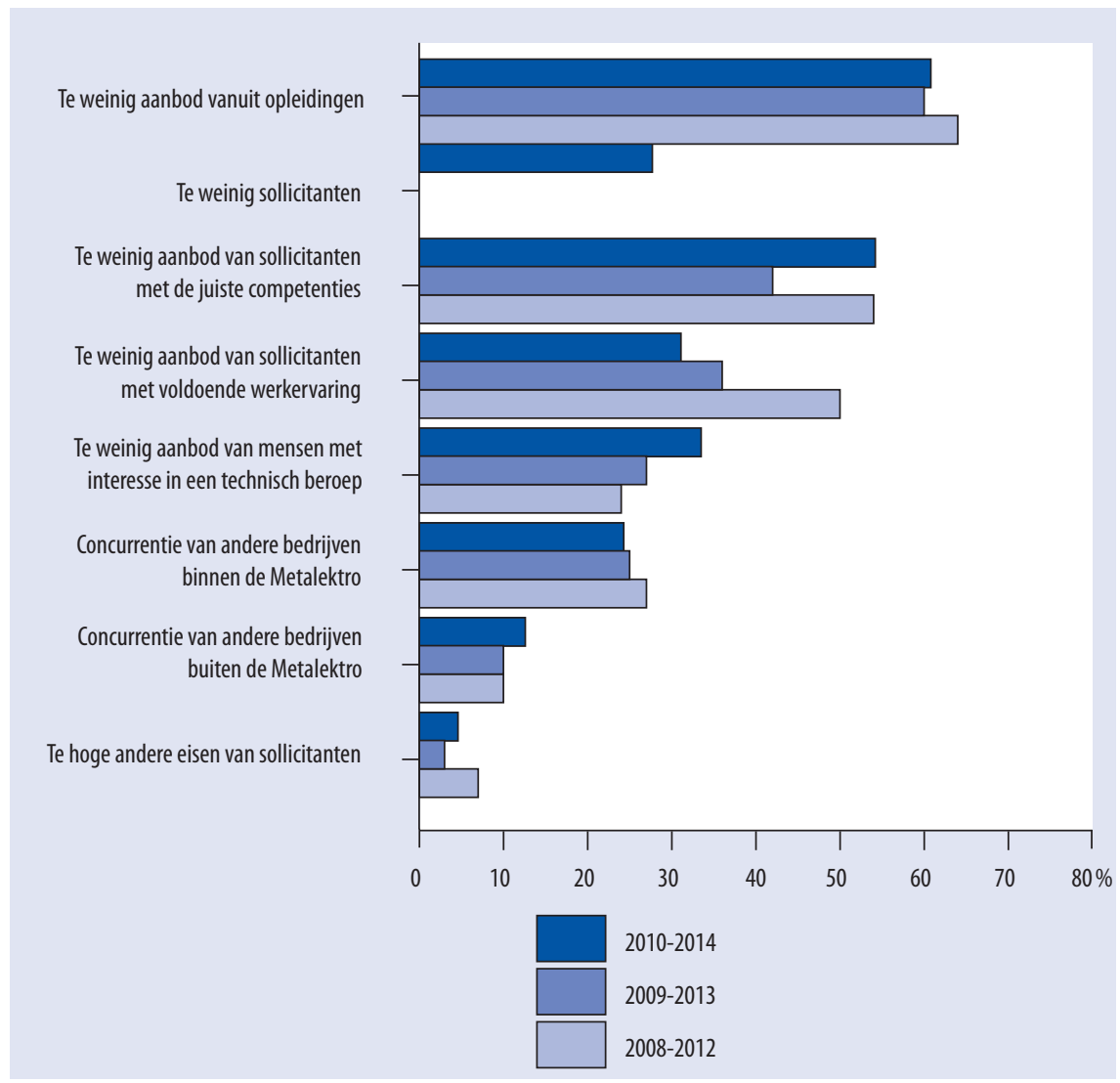

Bron: ROA / Werkgeverspanel Metalektro 2007-2009

Een tweede problematiek is de kwaliteit van het aanbod van sollicitanten. Veel bedrijven verwachten de komende vijf jaar met name problemen bij het vinden van nieuwe medewerkers die over de juiste competenties beschikken. In 2009 noemde $54 \%$ van de bedrijven dit als één van de problemen te verwachten bij het vinden van technisch personeel in de komende vijf jaar. Ook de afgelopen jaren werd het probleem dat de sollicitanten in de toekomst niet de juiste competenties zullen hebben, als het grootste probleem voor de nabije toekomst ervaren. $31 \%$ van de bedrijven verwacht problemen met het krijgen van sollicitanten met voldoende werkervaring. Dit is wel duidelijk minder dan in de voorgaande jaren werd verwacht. De nieuw toegevoegde categorie "te weinig sollicitanten" wordt door $28 \%$ van de bedrijven aangekruist. 
De bedrijven zien de concurrentie van andere bedrijven als een minder groot probleem dan het gebrek aan de juiste sollicitanten. Concurrentie op de arbeidsmarkt verwachten metalektrobedrijven vooral vanuit de eigen bedrijfstak (24\%), terwijl slechts $13 \%$ van de bedrijven bij de werving van personeel de concurrentie van buiten de bedrijfstak vreest. Een opkomend probleem, gelet op de stijgende lijn, is het afnemend aanbod van mensen die geïnteresseerd zijn in een technisch beroep. In 2007 noemde $24 \%$ van de bedrijven dit probleem, tegenover $34 \%$ in 2009 . Dit illustreert dat er onder de metalektrobedrijven een toenemende bewustwording van dit probleem is, dat de bedrijven op verschillende manieren proberen tegen te gaan. Zo proberen veel bedrijven van de technische sector al dan niet in samenwerking met TechniekTalent. $n u$ en Jet-net meer jongeren voor de techniek te interesseren.

\subsection{Verandering in de technische functies op de middellange termijn: 2010-2014}

De verwachte veranderingen in de technische functies zijn onder andere van belang bij het bepalen van de gewenste competenties van de zittende technici (zie paragraaf 4.I) en van de technici die in de toekomst in de bedrijfstak zullen instromen. De verwachte veranderingen in de technische functies zijn daardoor ook van groot belang voor het beroepsonderwijs. In paragraaf 4.I zijn de verwachte veranderingen op de korte termijn, i.e. binnen een jaar, al besproken, terwijl de huidige paragraaf zich richt op de middellange termijn.

Heeft de crisis voor een trendbreuk gezorgd in het verwachtingspatroon over het functieprofiel van toekomstige technici? Een vergelijking van de verwachtingen op middellange termijn van de afgelopen jaren laat zien dat dit nauwelijks het geval is (zie figuur 7.4). De meeste veranderingen worden door vrijwel evenveel bedrijven genoemd als in het voorgaande jaar. Dit is ook niet zo verwonderlijk aangezien de inhoud van functies vooral verandert door technologische en sociale innovaties. Zoals in de hoofdstukken I en 5 is besproken, blijven veel metalektrobedrijven innovaties doorvoeren en zullen ze dat ook op de middellange termijn blijven doen.

Er zijn twee veranderingen die bij de laatste meting door minder bedrijven zijn genoemd dan een jaar eerder. Ten eerste verwachtte in 2008 nog $57 \%$ van de bedrijven dat gedragsmatige competenties in de komende vijf jaar (2009-20I3) belangrijker zouden worden, terwijl deze verwachting nu nog leeft onder $48 \%$ van de bedrijven (voor de periode 20IO-20I4). Ondanks deze afname is dit nog altijd één van de verwachte functieveranderingen die de bedrijven het vaakst noemen. De tweede verandering heeft betrekking op het leggen van meer verantwoordelijkheden bij technici lager in de organisatie. Voor de komende vijf jaar verwacht $34 \%$ van de bedrijven dat er meer verantwoordelijkheden naar de lagere functieniveaus worden gedelegeerd. Dit was in de twee voorgaande jaren nog $46 \%$ en $50 \%$. Dit zou erop kunnen wijzen dat een aantal bedrijven vindt dat deze decentralisering van verantwoordelijkheden momenteel het optimale niveau heeft bereikt. 
Figuur 7.4 laat zien dat de vaakst genoemde veranderingen betrekking hebben op technici die meer allround zullen worden en die de gedragsmatige competenties (POFI+) goed beheersen. Deze flexibilisering van functies en werkzaamheden past in de veranderde structuur van veel bedrijven. Aan de andere kant verwacht een derde van de bedrijven dat functies juist specialistischer zullen worden. Het is heel goed mogelijk dat de aard van de producten en/of de markt waarin een deel van de metalektrobedrijven opereren, er voor zorgen dat het belang van specialisatie juist toeneemt. Opmerkelijk is echter wel dat $37 \%$ van de bedrijven die verwachten dat technische functies meer allround zullen worden, tegelijkertijd verwacht dat technische functies de komende jaren specialistischer zullen worden. Dit laat zien dat een deel van de bedrijven de komende jaren zowel allround ingestelde technici als specialistische technici nodig denkt te hebben.

\section{Figuur 7.4}

Verwachte veranderingen in functies van het technisch personeel in de komende vijf jaar (\% bedrijven)

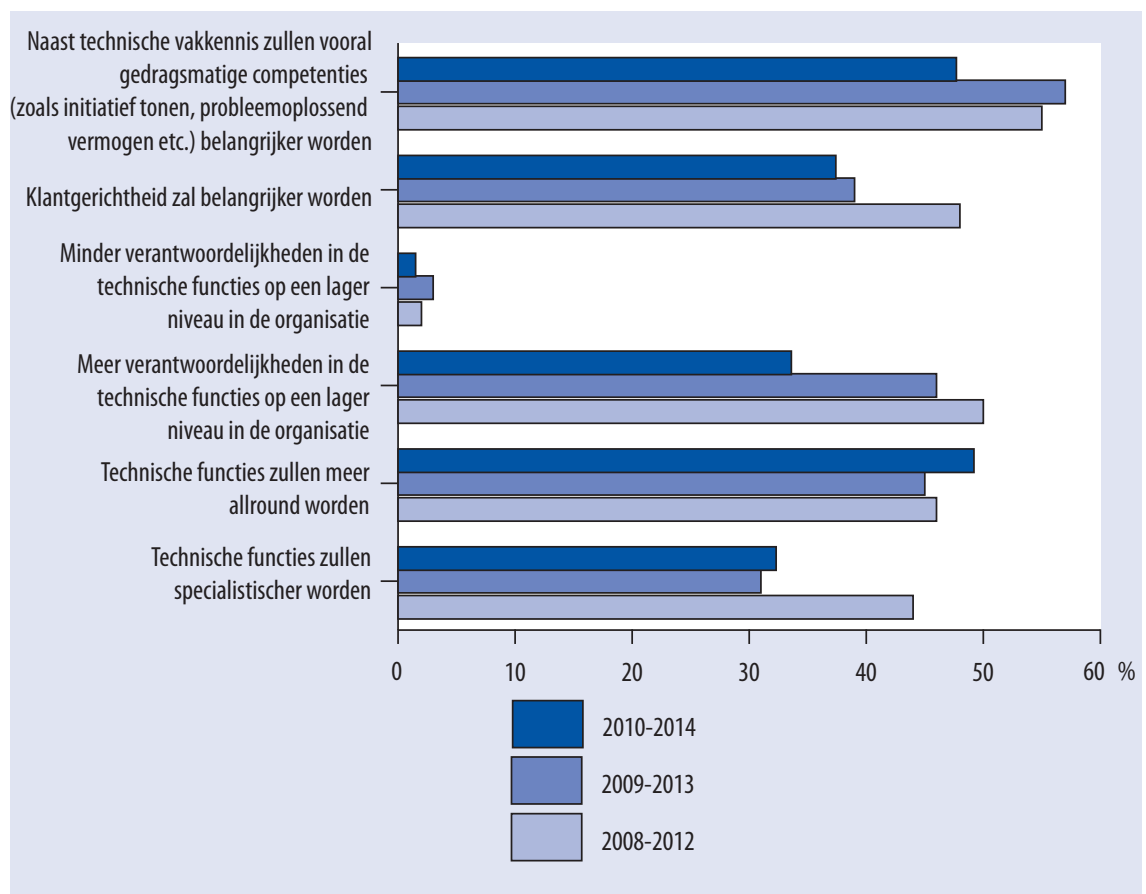

Bron: ROA / Werkgeverspanel Metalektro 2007-2009 


\subsection{HRM beleid op de middellange termijn: 2010-2014}

\section{Speerpunten}

Verreweg het belangrijkste speerpunt voor het personeelsbeleid in de komende vijf jaar is het bevorderen van de inzetbaarheid van het huidige personeel. In figuur 7.5 is te zien dat de crisis daar niets aan veranderd heeft: nog steeds heeft driekwart van de bedrijven het bevorderen van inzetbaarheid als speerpunt. Daarnaast is er veel aandacht voor loopbaanbeleid en voor het gaan voeren van een leeftijdsbewust personeelsbeleid. Dit laatste moet er toe leiden dat mensen langer productief inzetbaar blijven en minder snel de noodzaak voelen om met vervroegd pensioen te gaan. Ook het verminderen van het verzuim en coachend leiderschap staan nog altijd hoog op de agenda voor het personeelsbeleid.

\section{Figuur 7.5}

Speerpunten personeelsbeleid voor de komende vijf jaar (\% bedrijven)

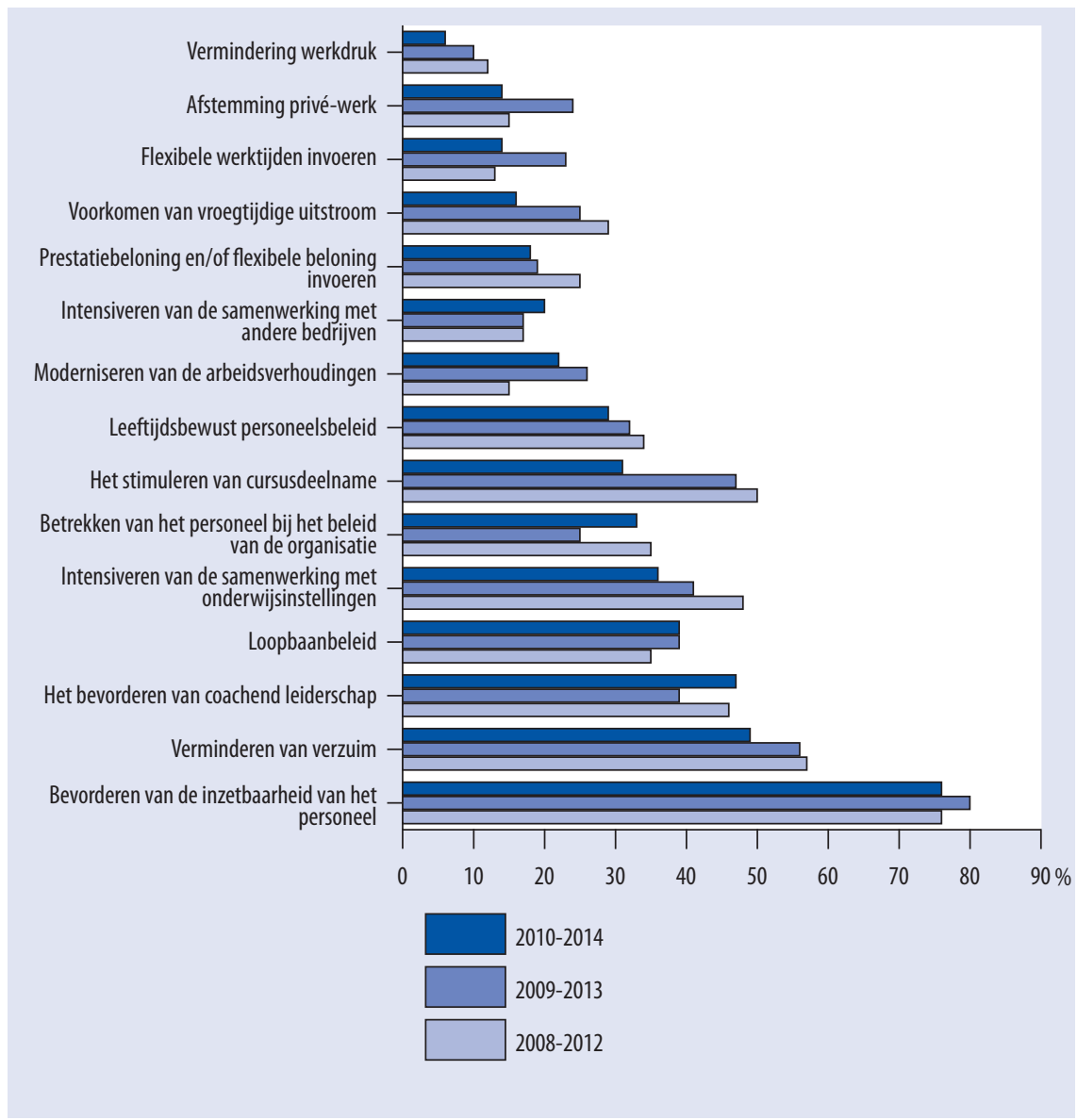

Bron: ROA / Werkgeverspanel Metalektro 2007-2009 
De crisis lijkt vooral effect te hebben gehad op het belang van de speerpunten met betrekking tot de scholing van het personeel: zowel het speerpunt stimuleren van cursusdeelname als het speerpunt intensievere samenwerking met onderwijsinstellingen worden in de laatste meting minder vaak genoemd dan in de jaren ervoor. Het stimuleren van cursusdeelname is voor bijna een derde van de bedrijven in 2009 nog een speerpunt, terwijl dit in 2007 nog bij de helft van de bedrijven het geval was. Het belang dat de metalektrobedrijven hechten aan het intensiveren van de samenwerking met onderwijsinstellingen als toekomstig speerpunt voor het personeelsbeleid is teruggelopen van $48 \%$ van de bedrijven in 2007 naar $36 \%$ in 2009 . Deze dalingen zijn waarschijnlijk ook mede het gevolg van de vele cursussen die tijdens de crisis door het metalektropersoneel zijn gevolgd en de daarmee samenhangende toegenomen samenwerking tussen metalektrobedrijven en het onderwijs. In dat geval is de daling niet per se een negatief signaal, maar geeft het aan dat bij verschillende bedrijven deze speerpunten al voldoende gerealiseerd zijn. Echter, als de dalingen mede het gevolg zijn van een afgenomen belangstelling voor cursusdeelname en intensievere contacten met het onderwijsveld, zou men wel eens van een koude kermis thuis kunnen komen. Immers, bedrijven met nauwe banden met het onderwijs zullen veel gemakkelijker schoolverlaters kunnen aantrekken als de arbeidsmarkt straks weer krapper wordt, dan bedrijven die deze banden momenteel veronachtzamen.

Het is ook opvallend dat een aantal speerpunten in 2009 door minder bedrijven wordt genoemd dan in 2008, terwijl het hier toch om plannen voor de middellange termijn gaat. Dit wijst er op dat verschillende bedrijven door de crisis enkele speerpunten van hun personeelsbeleid zijn gaan herzien of op de langere baan hebben geschoven. Naast de hiervoor besproken terugval in het stimuleren van cursusdeelname en de intensivering van samenwerking met het onderwijs, zijn ook flexibele werktijden ( $23 \%$ in $2008,14 \%$ in 2009), afstemming privé-werk (24\% in 2008 , $14 \%$ in 2009 ) en het voorkomen van vroegtijdige uitstroom van het personeel (25\% in $2008,16 \%$ in 2009 ) bij een aantal bedrijven uit de personeelsagenda voor de komende jaren verdwenen.

Een deel van de bedrijven lijkt dus een aantal speerpunten te hebben losgelaten onder druk van de crisis, terwijl andere bedrijven er juist aan vast hebben gehouden. Deze tweedeling ten aanzien van het te voeren personeelsbeleid op de middellange termijn zien we ook terug in de reacties op de Quickscanstelling "Ondanks de crisis houdt ons bedrijf vast aan het personeelsbeleid van voor de crisis.": $48 \%$ van de bedrijven is het met de Quickscanstelling eens, terwijl 34\% het hiermee oneens is.

\section{Instrumenten}

Om de beoogde speerpunten om te zetten in daadwerkelijk beleid hebben de metalektrobedrijven een heel scala aan instrumenten ter beschikking. Van deze HR-instrumenten worden functioneringsgesprekken, beoordelingsgesprekken, scholings- en ontwikkelingsgesprekken, werkoverleg en opleidingsfaciliteiten al door het overgrote deel (70\% of meer) van de bedrijven gebruikt (zie hoofdstuk 4). Daarnaast 
zijn er bedrijven die deze instrumenten nog niet gebruiken, maar dat in toekomst wel willen doen (zie figuur 7.6). De meeste aandacht gaat de komende jaren echter uit naar HR-instrumenten die gericht zijn op een planmatige ontwikkeling van het personeel, zoals loopbaanplanning, bedrijfs- en persoonlijke opleidingsplannen, EVC's en competentiemanagement.

\section{Figuur 7.6}

HR-instrumenten voor de komende vijf jaar (\% bedrijven)

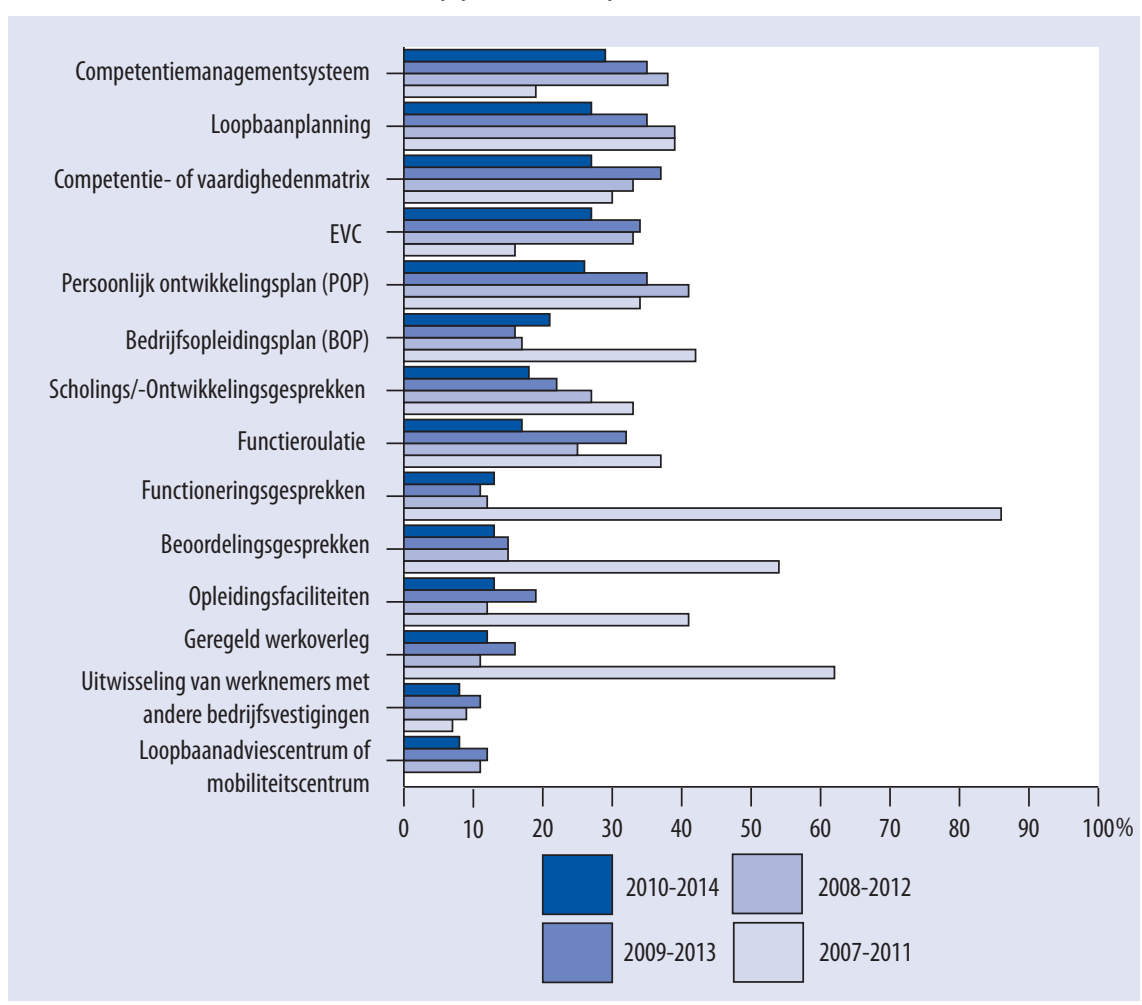

Bron: ROA / Werkgeverspanel Metalektro 2007-2009

\section{Knelpunten}

Ruim een derde van de bedrijven denkt dat de realisatie van de speerpunten van hun HRM-beleid zou kunnen stranden op personeel dat moeite heeft met de beoogde veranderingen. Andere vaakgenoemde struikelblokken voor een succesvolle invoering van nieuwe HR-instrumenten zijn een te laag kennisniveau bij het personeel (26\%) en onvoldoende budget (25\%). Verder vindt een deel van de bedrijven dat toekomstige veranderingen in het personeelsbeleid stuk zouden kunnen lopen op personeel dat niet in zichzelf wil investeren ( $19 \%$ ) of niet flexibel genoeg is ( $18 \%$ ). Opvallend is hierbij wel dat dit gebrek aan flexibiliteit door veel minder bedrijven wordt genoemd 
dan in voorgaande jaren. In 2008 verwachtte nog $31 \%$ van de bedrijven dat de flexibiliteit van hun personeel tekort zou schieten om de speerpunten van hun HRM-beleid te kunnen realiseren. In 2009 leefde zoals gezegd deze verwachting nog slechts bij I $8 \%$ van de bedrijven. Dit zou er op kunnen wijzen dat door de huidige economische crisis ook het personeel beseft dat het voor het handhaven van de concurrentiepositie van het bedrijf noodzakelijk is om open te staan voor veranderingen in de organisatie en het vergroten van de eigen inzetbaarheid. Ook bij andere personeelsgerelateerde factoren is een afname te zien van het aantal bedrijven dat gebrek aan flexibiliteit bij het personeel als een mogelijk struikelblok voor het realiseren van hun HRM-speerpunten noemt.

Figuur 7.7

Knelpunten bij het realiseren van speerpunten van het HRM-beleid (\% bedrijven)

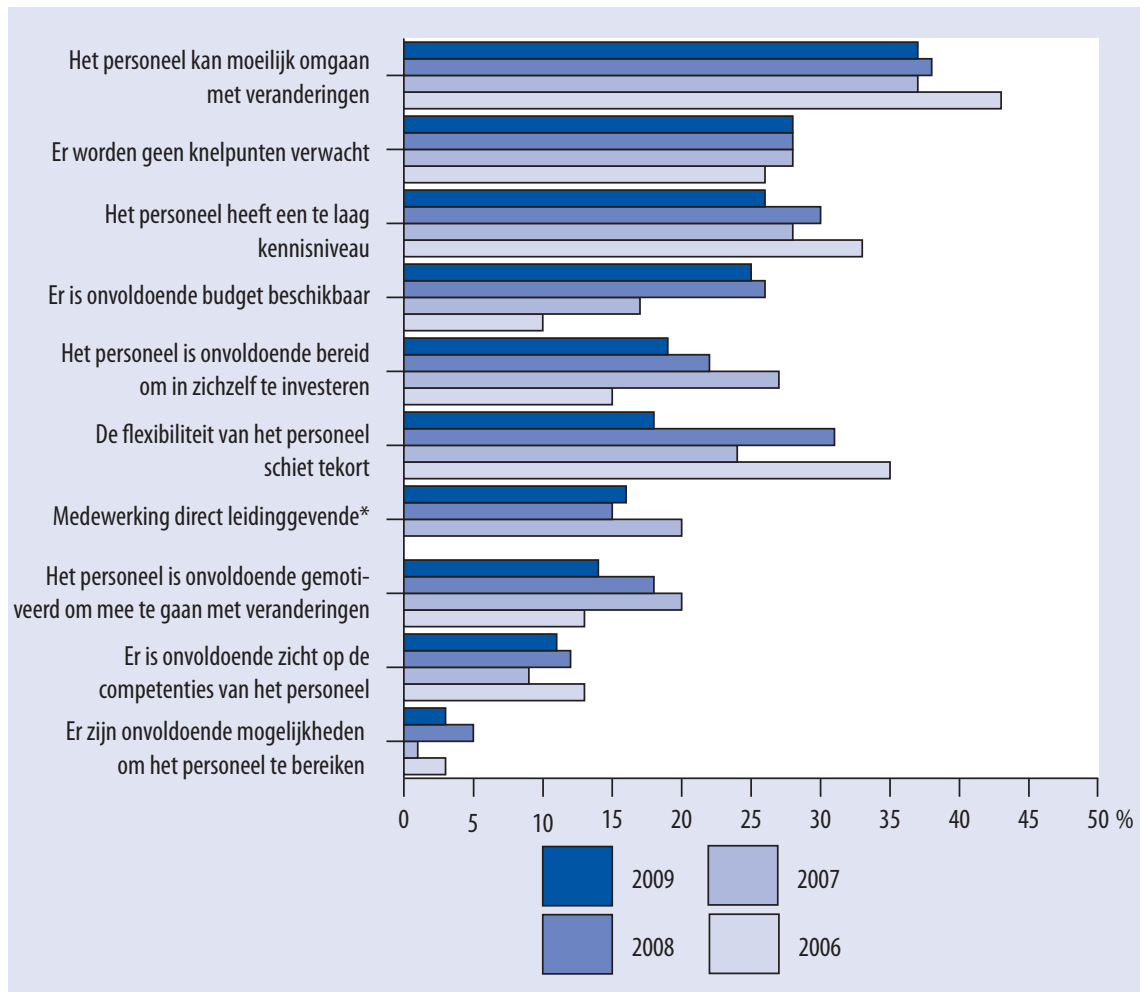

Bron: ROA / Werkgeverspanel 2006-2009

* Opmerking: pas vanaf 2007 in meting 


\section{Agenda voor de Toekomst}

In dit hoofdstuk worden de belangrijkste ontwikkelingen in de Metalektro in vogelvlucht besproken en zien we wat deze ontwikkelingen betekenen voor het beleid van de bedrijven. In paragraaf8. I wordt achtereenvolgens ingegaan op de huidige economische crisis, het loopbaanmanagement, de voortschrijdende upgrading van het gevraagde competentieniveau en de vraag naar POFI+ competenties, het opleidingsbeleid, speerpunten toekomstig personeelsbeleid, sociale innovatie en het levensfasebewuste personeelsbeleid van de bedrijven. Daarna presenteren we in paragraaf 8.2 een vernieuwde Agenda voor de Toekomst. Deze agenda biedt metalektrobedrijven handreikingen om de komende jaren de effectiviteit van bun arbeidsmarkt-en personeelsontwikkelingsbeleid te vergroten.

\subsection{Ontwikkelingen en trends}

\section{Economische crisis}

De Metalektro kampt sinds het najaar van 2008 met de economische crisis. Een groot aantal bedrijven wordt daarbij geconfronteerd met een aanzienlijke vraaguitval en een krimpende werkgelegenheid. In 2009 is het aantal werknemers in de Metalektro flink gedaald. De uitstroom van personeel was hoog en de instroom bleef laag. Ten dele konden metalektrobedrijven de teruggang in de productie compenseren door te snijden in de 'flexibele schil' die zij in voorgaande jaren hadden opgebouwd. Door het afstoten van uitzendkrachten en tijdelijk personeel waren bedrijven in staat om hun kernpersoneel te behouden. Ook hebben bedrijven werk dat eerder was uitbesteed aan andere bedrijven, weer naar zich toegetrokken. Bovendien zijn er voornamelijk laagopgeleide werknemers afgevloeid. Hun taken zijn deels door de vakkrachten overgenomen. Dit alles heeft er toe bijgedragen dat veel metalektrobedrijven hun vaste vakkrachten, ondanks de grote terugval in de afzet, hebben kunnen behouden.

Het aantal vacatures is door de cursus begrijpelijkerwijs behoorlijk teruggelopen. Er waren sinds het bestaan van de Arbeidsmarktmonitor nog nooit zo weinig vacatures in de Metalektro als in 2009 en de vacatures die er zijn, worden sneller vervuld dan voorheen. De eerste tekenen van herstel van het aantal vacatures hebben zich overigens al weer aangediend. Ondanks de terugval in het aantal vacatures verwachten veel bedrijven voor de komende vijf jaar problemen bij de vervanging van hun personeel 
dat met pensioen gaat. Bedrijven zullen dit moeten opvangen door een lange termijn personeelsplanning aangevuld met een goed wervingsbeleid.

\section{Loopbaanmanagement}

Goed loopbaanmanagement zorgt ervoor dat bedrijven de competenties in huis hebben die enerzijds passen bij de huidige behoeftes en het bedrijf anderzijds voorbereid op toekomstige ontwikkelingen. Dit wordt bereikt door de competenties/vaardigheden van werknemers in kaart te brengen en deze af te zetten tegen de huidige en de toekomstige behoeftes. Door goed loopbaanmanagement wordt de inzetbaarheid van werknemers verbeterd, zowel binnen als buiten het eigen bedrijf en kan een werknemer doorgroeien zowel qua competenties/vaardigheden als verantwoordelijkheden. Goed loopbaanmanagement is ook het bieden van een ontwikkelingspad aan jonge medewerkers die kampen met aansluitingsproblemen tussen de gevolgde opleiding en de eisen die hun functie stelt. Vanzelfsprekend is een goed loopbaanmanagement ook nauw verbonden met het opleidingsbeleid van het bedrijf. In dat geval is er sprake van een personeelsontwikkelingsbeleid.

Een goed loopbaanmanagement start met het in kaart brengen van het competentieen vaardighedenniveau van de medewerkers. Functioneringsgesprekken zijn inmiddels gemeengoed in de Metalektro: in 2009 voert negen van de tien bedrijven dergelijke gesprekken, vier van de vijf houdt tevens beoordelingsgesprekken, terwijl twee op de vijf bedrijven een competentie- of vaardighedenmatrix op stelt. Ook het gebruik van EVC's is in 2009 duidelijk toegenomen.

De interne mobiliteitsperspectieven die een bedrijf biedt bevorderen ook een optimale ontwikkeling van de competenties en werkervaring van het personeel. De economische crisis heeft echter een remmend effect op de interne mobiliteit gehad. Slechts een derde van de bedrijven geeft aan dat technici zijn doorgestroomd naar een andere technische functie. Dit is bijna een halvering ten opzichte van 2008. Bovendien liggen de functies vaker op hetzelfde of zelfs op een lager niveau. Dit in tegenstelling tot voorgaande jaren waarin werknemers vaker doorstroomden naar een functie op een hoger niveau.

\section{Voortschrijdende upgrading en vraag naar POFI+ competenties}

De dynamiek van de Metalektro zal de komende jaren onveranderd groot blijven. Product- en procesinnovaties en de daaraan gerelateerde sociale innovaties leiden in veel bedrijven tot een upgrading van de vereiste competenties. De huidige economische crisis versterkt het upgraden van het personeelsbestand door de toegenomen behoefte aan breed inzetbaar personeel. Dit uit zich ook in de toenemende vraag naar allround technici die verantwoordelijkheid kunnen dragen voor de invulling van hun werk. Het is vooral de concurrentie op de afzetmarkt die vereist dat het technisch personeel naast de noodzakelijke vaktechnische competenties beschikt over 
de gedragsmatige competenties die in de vorige edities van de Arbeidsmarktmonitor Metalektro zijn benadrukt in de POFI+ agenda. Deze bestaat uit de volgende competenties:

- Probleemoplossend vermogen.

- Omgaan met veranderingen.

- Omgaan met klanten.

- Flexibiliteit.

- Initiatief.

\section{Opleidingsbeleid}

De vereiste upgrading van het personeel en de toenemende vraag naar technici die beschikken over de genoemde $P O F I+$ competenties vergen aanzienlijke investeringen in trainingen en opleidingen voor het personeel. Het is dan ook niet verwonderlijk dat de opleidingsuitgaven van de metalektrobedrijven, ondanks de druk van de economische crisis, in procenten van de loonsom in 2009 weer verder zijn gestegen. De gemiddelde opleidingskosten per getrainde werknemer zijn echter licht gedaald. Door de crisis is er meer tijd, maar minder geld om te trainen, waardoor er vooral meer werknemers intern worden bijgeschoold, liefst zonder te hoge kosten. Bij de meeste bedrijven ligt het accent in het scholingsbeleid nog steeds op de vaktechnische cursussen. Dit illustreert het grote belang dat veel bedrijven hechten aan het up-todate houden van de vaktechnische vaardigheden van hun technisch personeel. Veel bedrijven geven echter aan dat ze de trainingen in de komende jaren meer willen richten op het verbeteren van de communicatieve vaardigheden en het probleemoplossend vermogen van hun personeel. Dit illustreert dat de metalektrobedrijven zich nog steeds richten op het verder invullen van de POFI+ agenda.

Een positieve ontwikkeling in dit verband is ook dat er een duidelijke toename is van metalektrobedrijven waarvoor het bevorderen van coachend leiderschap een speerpunt is in het personeelsbeleid voor de komende jaren. Coachend leiderschap versterkt het informeel leren op het werk en biedt ook goede mogelijkheden om bij het personeel de POFI+ competenties "on-the-job" te laten verwerven.

\section{Speerpunten toekomstig personeelsbeleid}

Het aantal speerpunten van het personeelsbeleid dat bedrijven voor de komende vijf jaar aangeven is beduidend minder dan in de voorgaande jaren. Dit laat zien dat de huidige economische crisis ook gevolgen heeft voor het personeelbeleid op de middellange termijn. Verschillende bedrijven hebben door de crisis enkele speerpunten van hun personeelsbeleid herzien of op de langere baan geschoven.

Het belangrijkste speerpunt voor het personeelsbeleid blijft het bevorderen van de inzetbaarheid van het huidige personeel. Ook zijn veel bedrijven van plan om in de toekomst meer aandacht te besteden aan de loopbaanplanning van hun uitvoe- 
rend technisch personeel. Dit zou een belangrijke bijdrage kunnen leveren aan het vergroten van de motivatie van het personeel, waardoor ongewenst personeelsverloop wordt voorkomen. Ook het verminderen van verzuim en het bevorderen van coachend leiderschap staan nog altijd hoog op de agenda voor het toekomstig personeelsbeleid. Dit coachend leiderschap is belangrijk om het proces van "boeien en binden" nog verder te versterken.

\section{Leeftijdsfasebewust personeelsbeleid stagneert}

Het aantal bedrijven dat problemen verwacht bij het vervangen van het technisch personeel dat de komende jaren met pensioen gaat, nam tot 2009 gestaag toe. In 2009 is het aantal bedrijven dat vervangingsvraagproblemen verwacht echter afgenomen. Voor de uitvoerende technici verwacht nog twee derde van de bedrijven problemen, terwijl de helft van de bedrijven de komende vijf jaar vervangingsproblemen verwacht voor de andere functies. Dit kan met de verwachting van de tijdelijk teruglopende pensioensuitstroom te maken hebben, of met de verwachting dat de ruime arbeidsmarkt nog enkele jaren aanhoudt. Een teruglopende pensioensuitstroom door langer doorwerkende oudere werknemers zorgt voor een nog 'grijzer' personeelsbestand bij veel metalektrobedrijven. Deze ontwikkeling makt het nog belangrijker om voldoende aandacht te hebben voor de inzetbaarheid van oudere medewerkers. Het aantal bedrijven waarvoor een leeftijdsbewust personeelsbeleid de komende jaren een speerpunt vormt in het personeelsbeleid is in 2009 echter nog verder afgenomen. Meer dan zeven van de tien bedrijven lijkt hier onvoldoende aandacht voor te hebben. De inzet van active ageing instrumenten in het personeelbeleid bereikte in 2009 een dieptepunt. Het blijkt dat de helft van de bedrijven geen enkel active ageing instrument inzet. Door de crisis waren bedrijven eerder geneigd om hun oudere werknemers te stimuleren met pensioen te gaan, dan ze tot langer doorwerken te stimuleren.

Zo is er een sterke terugval in het aantal bedrijven dat probeert de kennis en vaardigheden van hun oudere medewerkers op een optimale wijze te benutten en de werkzaamheden van oudere medewerkers beter afstemt op hun wensen. Wanneer oudere medewerkers hierdoor minder goed inzetbaar worden, kan dat op termijn negatieve gevolgen hebben. Dit zal vooral het geval zijn wanneer de arbeidsmarkt weer aantrekt.

\section{Sociale innovatie}

Er is een toename van het aantal sociale innovaties ten opzichte van voorgaande jaren: in negen van de tien bedrijven werd in 2009 minimaal één vorm van sociale innovatie doorgevoerd, gemiddeld zelfs vier verschillende vormen per bedrijf. Sociale innovatie is vooral gericht op het verhogen van de productiviteit en de kwaliteit van de producten. Daarnaast wordt het flexibiliseren van het productieproces als doelstelling genoemd. Bij de implementatie van sociale innovatie geeft driekwart van de bedrijven aan dat deze naar wens verlopen is. De problemen die bedrijven bij het implementeren van sociale innovaties ondervinden, hebben vooral betrekking op het 
tekortschieten van de kennis en vaardigheden van het personeel en het gebrek aan tijd of menskracht. Ter ondersteuning van sociale innovatie gaat het komende jaar bij de metalektrobedrijven de meeste aandacht uit naar HR-instrumenten die gericht zijn op de planmatige ontwikkeling van het personeel, zoals loopbaanplanning, bedrijfsen persoonlijke opleidingsplannen, EVC's en competentiemanagement. Zo hopen de bedrijven hun personeel voor te kunnen bereiden op toekomstige technologische en sociale innovaties.

\section{Verspreiding good practices en HR tools}

Kleinere en middelgrote bedrijven blijken vaak onvoldoende mogelijkheden te hebben om hun personeelsontwikkelings- en arbeidsmarktbeleid op eigen kracht verder te ontwikkelen. Regionale samenwerking met andere bedrijven kan hier een oplossing bieden. Dit is zeker het geval wanneer kleinere bedrijven onvoldoende informatie hebben over de mogelijkheden tot en de voor- en nadelen van verschillende sociale innovaties. Daarbij gaat het ook om de overdracht van "good practices". Het gaat hierbij vooral om het identificeren van initiatieven op het vlak van het arbeidsmarkten personeelsbeleid die bij andere bedrijven hun effectiviteit hebben bewezen.

De overdracht van good practices kan er ook toe bijdragen dat niet ieder bedrijf zelf op zoek hoeft te gaan naar de wijze waarop bepaalde vormen van sociale innovatie ontwikkeld en geïmplementeerd kunnen worden. Daarbij is het van groot belang dat de inzichten die verkregen zijn uit de good practices vertaald worden in een aantal toegankelijke, gemakkelijk hanteerbare en direct implementeerbare tools. Met behulp van deze concrete HR-tools kunnen veel bedrijven in de Metalektro de effectiviteit van hun arbeidsmarkt- en personeelsontwikkelingsbeleid vergroten.

\subsection{Agenda voor de Toekomst}

Wat betekenen de ontwikkelingen in de Metalektro voor het beleid dat de bedrijven de komende jaren moeten gaan voeren? We vatten de belangrijkste punten samen in de Agenda voor de Toekomst. Vanzelfsprekend bouwt deze Agenda voor de Toekomst voort op de in de vorige edities van de Arbeidsmarktmonitor geformuleerde aandachtspunten.

\section{Lange-termijn strategie personeelsbehoefte}

Bedrijven zullen moeten proberen om hun HR-beleid in te bedden in een langetermijn strategie voor het invullen van hun personeelsbehoefte en de timing van het weer opbouwen van de flexibele schillen die men in de huidige crisis heeft afgestoten. Startpunt van deze strategie is het zo goed mogelijk in kaart brengen van de verwachte personeelsbehoefte in de komende jaren. Daarbij is het vooral ook belangrijk om een goed beeld te krijgen van de omvang van de toekomstige vervangingsvraag. Dit kan 
ook een belangrijke leidraad bieden voor het opleidings-, ontwikkelings- en wervingsbeleid van de metalektrobedrijven in de komende jaren.

Daarom zal vanuit deze lange-termijn strategie moeten worden bezien in hoeverre de hieronder genoemde actiepunten binnen het bedrijf meer of minder accent moeten krijgen.

\section{Opleidings- en ontwikkelingsbeleid}

Naast het investeren in vaktechnische vaardigheden en de inspanningen om de upgradingsdoelstellingen te realiseren, moet door de metalektrobedrijven ook worden ingespeeld op de toenemende behoefte aan allround vakmensen die verantwoordelijkheid kunnen dragen voor de invulling van hun eigen werkzaamheden. Werknemers moeten voorbereid worden op toekomstige innovaties zodat deze een goede kans van slagen hebben. Dit vereist een toenemende aandacht voor de vijf essentiële gedragsmatige competenties, die we kunnen aanduiden als de POFI+ agenda:

- Probleemoplossend vermogen.

- Omgaan met veranderingen.

- Omgaan met klanten.

- Flexibiliteit.

- Initiatief.

Metalektrobedrijven moeten daarom in hun opleidings- en ontwikkelingsbeleid veel aandacht schenken aan het versterken van de $P O F I+$ competenties van hun technisch personeel. Dit kan zowel door formele scholing als ook door gestructureerd gebruik te maken van informeel leren op de werkvloer, waarvan de effectiviteit versterkt kan worden door coachend leiderschap.

\section{Loopbaanmanagement}

Het HR beleid van de metalektrobedrijven moet zich meer gaan richten op het stimuleren van verschillende vormen van interne mobiliteit, niet alleen vanwege de innovatiedynamiek en de behoefte aan flexibel, breed inzetbaar personeel, maar ook om het personeel aantrekkelijke loopbanen te kunnen bieden en ongewenst verloop te voorkomen. Door het creëren van functies waarin werknemers verschillende aan elkaar gerelateerde taken vanuit een eigen verantwoordelijkheid uitvoeren, ontstaat hoogwaardige werkgelegenheid die medewerkers boeit en bindt en de aantrekkingskracht van de Metalektro op de arbeidsmarkt vergroot. Daarbij kan coachend leiderschap de loopbaanperspectieven van het personeel versterken. 


\section{Sociale innovatie}

Net zoals de technologische innovatie de voor de concurrentiepositie van het bedrijf noodzakelijke vernieuwing van producten en processen voortbrengt, zo zijn ook sociale innovaties steeds bepalender geworden voor het concurrentievermogen van bedrijven. Dit vereist dat bedrijven het innovatievermogen van het HRM beleid vergroten binnen de grenzen van de mogelijkheden die het bedrijf hiervoor heeft. Om dit te realiseren moeten bedrijven zich niet richten op het simpelweg kopiëren van populaire 'best practices', maar meer aandacht geven aan Research \& Development (R\&D) met betrekking tot sociale innovatie, op soortgelijke wijze als ze dat doen bij technologische innovaties. Alle stappen ontwikkeling, implementatie én evaluatie moeten hierbij de nodige aandacht krijgen. Ook op dit punt is het verbeteren van de samenwerking met kennisinstellingen gewenst.

\section{Levensfasebewust personeelsbeleid}

De verdere ontwikkeling van levensfasebewust personeelsbeleid dat gericht is op vier cruciale elementen:

- Een pro-actief levensfasebewust personeelsbeleid voor alle werknemers.

- Investeren in de competentieontwikkeling van het oudere personeel door scholing, functieroulatie en informeel leren.

- Het faciliteren van de doorstroom van fysiek of mentaal zware functies naar andere, minder belastende functies binnen of buiten het eigen bedrijf.

- Zorgen dat oudere werknemers zo lang mogelijk productief aan de slag kunnen blijven door middel van een gericht active ageing beleid.

- Het stimuleren van mobiliteit in de laatste loopbaanfase en het ontwikkelen van flexibele uittredemogelijkheden die aansluiten bij de behoeften van het bedrijf en de medewerkers.

\section{Wervingsbeleid}

Wanneer de economie weer aantrekt, zullen metalektrobedrijven weer snel geconfronteerd worden met een krappe arbeidsmarkt voor technisch opgeleiden. Dit vereist dat bedrijven hun wervingskracht vergroten door een beleid dat zich richt op:

- Het bieden van een aantrekkelijk loopbaanperspectief aan nieuwe medewerkers.

- Het verder ontwikkelen van innovatieve manieren van samenwerking met het onderwijsveld.

- Het verbeteren van het imago van de Metalektro.

- Het zelf opleiden van nieuwe medewerkers. 


\section{Verspreiding van good practices en HR tools}

Kleinere en middelgrote bedrijven moeten de effectiviteit van het arbeidsmarkt- en personeelsontwikkelingsbeleid vergroten door samenwerking en kennisdeling op regionaal niveau en het verspreiden van good practices en bruikbare HR- tools. Om deze vernieuwingsprocessen te ondersteunen zouden de kleinere bedrijven ook gezamenlijk innovatievouchers kunnen inzetten om de samenwerking met kennisinstellingen gericht op de implementatie van sociale innovaties te kunnen bekostigen. 